\title{
Experimental Work in Science Education from Green Chemistry Perspectives: A Systematic Literature Review Using PRISMA
}

\author{
Vesna Ferk Savec * and Katarina Mlinarec
}

check for updates

Citation: Ferk Savec, V.; Mlinarec, K. Experimental Work in Science Education from Green Chemistry Perspectives: A Systematic Literature Review Using PRISMA. Sustainability 2021, 13, 12977. https://doi.org/ $10.3390 /$ su132312977

Academic Editor: Maija Aksela

Received: 29 September 2021 Accepted: 18 November 2021 Published: 23 November 2021

Publisher's Note: MDPI stays neutral with regard to jurisdictional claims in published maps and institutional affiliations.

Copyright: (c) 2021 by the authors. Licensee MDPI, Basel, Switzerland. This article is an open access article distributed under the terms and conditions of the Creative Commons Attribution (CC BY) license (https:// creativecommons.org/licenses/by/ $4.0 /)$.
Faculty of Education, University of Ljubljana, SI-1000 Ljubljana, Slovenia; katarina.mlinarec@pef.uni-lj.si

* Correspondence: vesna.ferk@pef.uni-lj.si

\begin{abstract}
Experimental work is an important component of science subjects at all educational levels. The implication of green chemistry ideas indicated the need for optimization of traditional experimental work by implementing green chemistry principles to promote sustainable development. The aim of the study is to present findings from a systematic literature review on the use of experimental work in science education from green chemistry perspectives in the literature from 1995 to 2020. Thus, three electronic databases were reviewed following the Preferred Reporting Items for Systematic Reviews (PRISMA) guidelines. The literature search identified a total of 1199 papers from Web of Science $(\mathrm{N}=419)$, Scopus $(\mathrm{N}=578)$, and Education Resources Information Center (ERIC) $(\mathrm{N}=202)$. After applying inclusion/exclusion criteria, 263 papers were obtained and then analyzed in further detail. The findings highlighted trends in the integration of green chemistry principles into experimental work from primary to tertiary education levels and identified a literature gap, as well as the challenges and the possibilities for future development. The review outlined various opportunities for active learning within experimental work from green chemistry perspectives using a range of methods, with a particular focus on practical, hands-on, and laboratory activities.
\end{abstract}

Keywords: experimental work; green chemistry; practical work; PRISMA; science education

\section{Introduction}

Never have so many students been absent from school simultaneously as during 2020 as a result of the COVID-19 pandemic [1]. Therefore, it is even more important to advocate for higher quality education and pursue the fourth Sustainable Development Goal (SDG) from the 2030 Agenda framework [2,3] to ensure inclusive, equitable, and quality education, and promote lifelong learning opportunities for all $[4,5]$.

Attempts to advance sustainable thinking in practice by focusing on engaging networks of chemists and stakeholders to develop Education for Sustainable Development (ESD) in many institutions go beyond COVID -19 pandemic [6-8]. In 1998, Anastas and Warner published Green Chemistry: Theory and Practice, in which they presented 12 Principles of Green Chemistry that describe what constitutes a greener chemical process, or product [9]: Prevention; Atom Economy; Less Hazardous Chemical Syntheses; Designing Safer Chemicals; Safer Solvents and Auxiliaries; Design for Energy Efficiency; Use of Renewable Feedstocks; Reduce Derivatives; Catalysis; Design for Degradation; Real-Time Analysis for Pollution Prevention and Inherently Safer Chemistry for Accident Prevention.

The American Chemical Society sees green chemistry as a field that is "open to innovation, new ideas, and revolutionary advances" [10]. The growing trend toward green chemistry has also had a significant impact on chemistry education [11,12]. The integration of sustainability and green chemistry in the education of future chemists and chemical engineers has been recognized as crucial to secure students a good position in the future job market and in their social roles [13-17]. This trend continued during the COVID-19 pandemic [18,19]. However, green chemistry topics have rarely been covered at the primary $[20,21]$ and secondary [22,23] education levels to date [24]. 
In terms of the terminology used, the authors point out that there is no such thing as "green" or "sustainable" in an absolute sense and that the pursuit of greener or more sustainable products, services, and approaches is a collective, i.e., a normative, construct. Therefore, should we refer to green chemistry as "greener chemistry" or "chemistry for greener products," circular chemistry as "chemistry in the context of a circular economy," and sustainable chemistry as "chemistry for sustainability" [25]? Zuin et al. claim that education is at the heart of understanding and projecting the future transformation of these normative parts of "chemistry," which is a fundamental key to understanding their socio-historical constitution [26].

As shown in the review by Andraos and Dicks [12], various approaches have been developed to introduce students to green chemistry ideas, e.g., the introduction of green chemistry into the curriculum [14,27,28], textbooks, and other learning materials [29-31], lectures and full courses in green chemistry [32-34], various types of metrics for determining the "greenness" of a chemical reaction [35-38], and experimental work related to the green chemistry principles [39-42].

In order to support further development of green chemistry education, which has been recognized as one of the important topics in ESD [11,15,17], and thereby to focus especially on the trends and the needs related to specific educational methods, this article focuses primarily on a review of laboratory experimental work related to green chemistry to support quality of education, as experimental activities are recognized to have a distinctive and central role in the science curriculum. In addition, numerous benefits have been reported from engaging students in science laboratory activities [43-49].

Hofstein [45] observed that the following important reasons are still relevant 30 years after his review on the use of laboratory work in chemistry education: (1) "School laboratory activities have special potential as media for learning that can promote important science learning outcomes for students; (2) Teachers need knowledge, skills and resources that enable them to teach effectively in practical learning environments. They need to be able to provide opportunities for students to interact both intellectually and physically by conducting hands-on investigations and minds-on reflection; (3) Student perceptions and behaviors in the science laboratory are greatly influenced by teacher expectations and assessment practices, as well as the orientation of the associated laboratory guide, worksheets, and electronic media; (4) Teachers need ways to find out what their students are thinking and learning in the science laboratory and classroom".

Experimental work is essential for the teaching and learning of chemistry because it combines several activities with different objectives. Therefore, the planning of its implementation must be guided by the effectiveness of the planned performance in achieving the learning objectives [50]. The important purpose of experimental work in science education is to help students make connections between real objects, materials, and events and the abstract world of thoughts and ideas [47]. Tiberghien [51] believes that experimental work can help students develop an understanding of the connection between the two levels of knowledge: the level of objects and observations and the level of ideas. Abrahams and Millar [47] found that experimental work is also crucial for students to learn how to use laboratory equipment, but educators should pay careful attention to improving its efficiency in facilitating students' learning based on the data collected for the development of scientific ideas.

Previous review articles have reported on various aspects of the use of green chemistry in education, e.g., laboratory work in tertiary education [12,27,52-59], often only in a specific field of chemistry [52,56,57], and the integration of selected green chemistry principles into laboratory work in tertiary education $[53,56,57]$. The present paper aims to review experimental work from green chemistry perspectives more holistically by involving all fields of chemistry, all educational levels, and 12 Principles of Green Chemistry in a 25-year long period. To examine the possibilities of experimental work in green chemistry education, the following research questions were established: 
RQ1: What are the characteristics (year of publication, journal of publication, ISSN [e-ISSN], type of paper, field of chemistry) of the reviewed papers published from 1995 to 2020?

RQ2: What are the main purposes of the reviewed papers?

RQ3: Which learning type is predominant in the reviewed papers?

RQ4: What education level do the reviewed papers focus on?

RQ5: Which green chemistry principles are addressed in the reviewed papers?

\section{Materials and Methods}

A systematic literature review method was used to address the objectives of the study and provide a comprehensive insight into the possibilities of experimental work in green chemistry education. To conduct a systematic literature review, we followed the updated Preferred Reporting Items for Systematic Reviews (PRISMA) 2020 guidelines [60], which focus on several aspects to ensure transparent, replicable, and scientifically adequate systematic reviews. Accordingly, a protocol was established to define the research questions and describe the chosen information sources, search strategy, selection criteria, data extraction, and analysis.

\subsection{Information Sources and Search Strategy}

The systematic literature review performed in this study comprised an advanced search of published articles between the years 1995 and 2020 in three electronic databases: Web of Science (WoS) Core Collection, Scopus, and Education Resources Information Center (ERIC). The selection of these three databases was based on their internationally recognized impact indices containing peer-reviewed scientific and scholarly literature published worldwide and across different scientific fields and disciplines [61,62].

The search strategy was based on the use of core concepts regarding the subject of the study (green chemistry, teach *, learn *, educ *, experiment *, practice *, laborator *) and research questions utilizing the Boolean operators (AND, OR) with simple operators using parentheses in the search string [63]. After testing and quickly reviewing the syntax required by each database, a search string was generated (Table 1 ).

Table 1. Information source and search strategy.

\begin{tabular}{|c|c|}
\hline Information Source & Search String and Parameters \\
\hline WoS Core Collection & 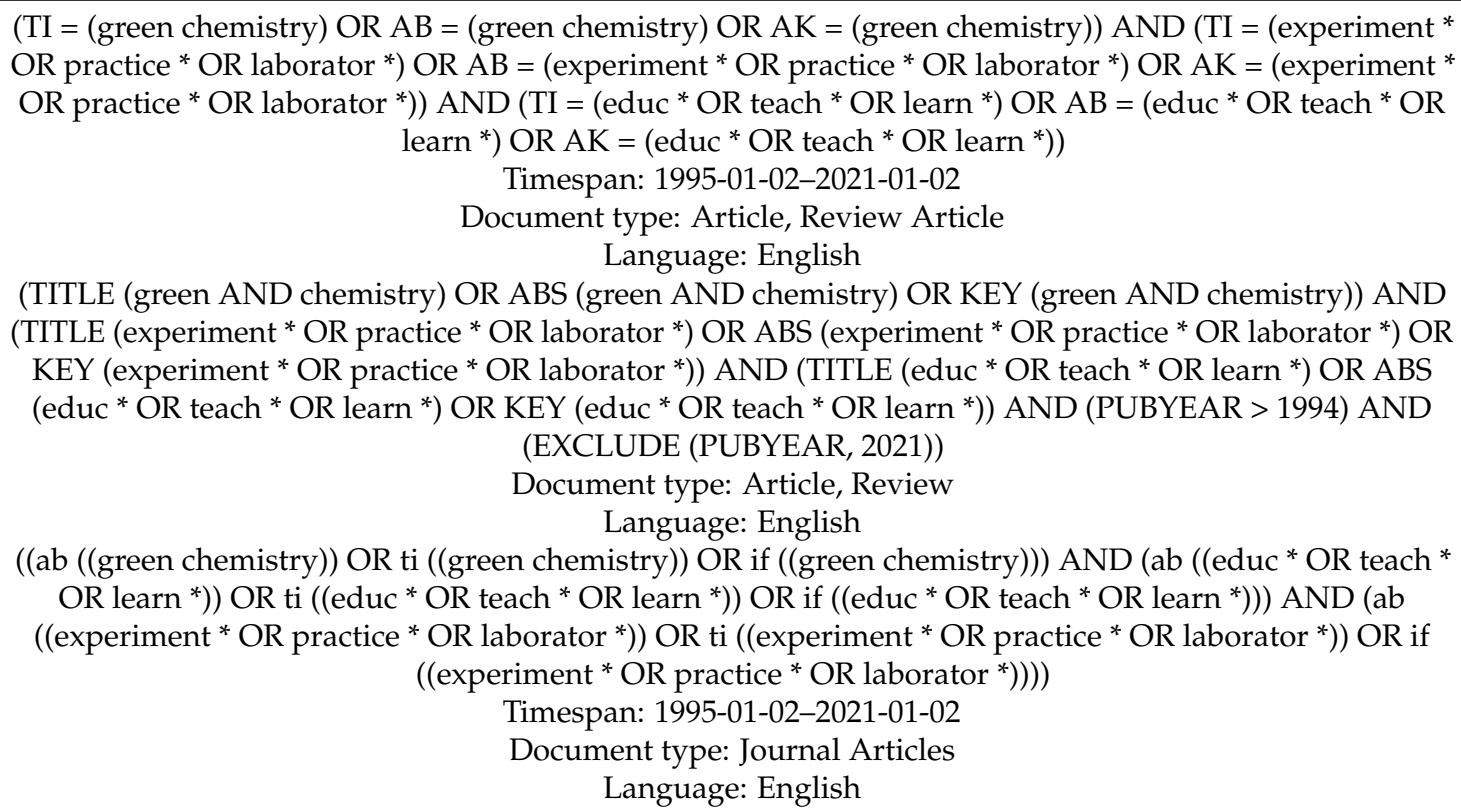 \\
\hline
\end{tabular}

Note: The asterisk $\left(^{*}\right)$ sign was used as a truncation operator. Asterisks were appended to the stem of a word, which allowed searching for all words containing that stem or the letters preceding the asterisk. 
Only peer-reviewed articles were included in the study to increase its credibility and integrity. In the continuation of the search, additional parameters (document type: articles, review articles; language: English) to refine the search results were used in each database based on the inclusion and exclusion criteria described in Section 2.2. To offer as broad an overview as possible, specific journals in the search strategy phase were not chosen [64]. The final search in all databases was performed in August 2021.

\subsection{Inclusion and Exclusion Criteria}

With the intention to select and include only relevant studies for our research topic identified from the databases, specific inclusion and exclusion criteria were defined.

\subsubsection{Inclusion Criteria}

IC1: Journal articles.

IC2: The study is written in English.

IC3: The study is peer-reviewed.

IC4: The study is not listed in another database.

IC5: The study was conducted in an educational environment (primary, secondary, or tertiary education).

IC6: The study is related to science subjects.

IC7: The full text of the study is available.

IC8: The study includes reviews, research, or descriptions of green chemistry practices.

IC9: The study addresses experimental work in green chemistry education.

\subsubsection{Exclusion Criteria}

EX1: Proceedings of congresses, conference papers, books, book chapters, and other nonpeer-reviewed publications.

EX2: The study is not written in English.

EX3: The study is not peer-reviewed.

EX4: The study is listed in another database.

EX5: The study was not conducted in an educational environment (primary, secondary, or tertiary education).

EX6: The study is not related to science subjects.

EX7: The full text of the study is not available.

EX8: The study only includes opinions about green chemistry practices.

EX9: The study does not address experimental work in green chemistry education or it mentions it just briefly.

\subsection{Data Collection and Analysis}

The systematic literature review was carried out in five phases following the PRISMA 2020 guidelines [65]. The first phase consisted of an initial search of the literature included in the WoS $(n=419)$, Scopus $(n=578)$, and ERIC $(n=202)$ electronic databases. Based on the inclusion (IC1, IC2, IC3) and exclusion (EX1, EX2, EX3) criteria, a total of 313 papers (305 chosen by database automation tools and eight by a human) were excluded as ineligible regarding the type of paper, language, and peer-review criteria. Regarding the inclusion and exclusion criteria (IC4, EX4) 409 duplicate papers were excluded using Microsoft Excel software. In the second phase, the inclusion (IC5, IC6) and exclusion (EX5, EX6) criteria were applied by reviewing the title and abstract of 476 papers. In case of insufficient or vague abstracts, the entire paper was browsed. Six papers that were not available in full text were excluded for further analysis (IC7, EX7). In the fourth phase, a total of 372 papers were carefully screened for eligibility by applying inclusion (IC8, IC9) and exclusion (EX8, EX9) criteria. In the fifth phase, the full text of the remaining 263 papers were reviewed thoroughly for relevance to our criteria and research questions. The described process is summarized in a PRISMA flow diagram (Figure 1). 


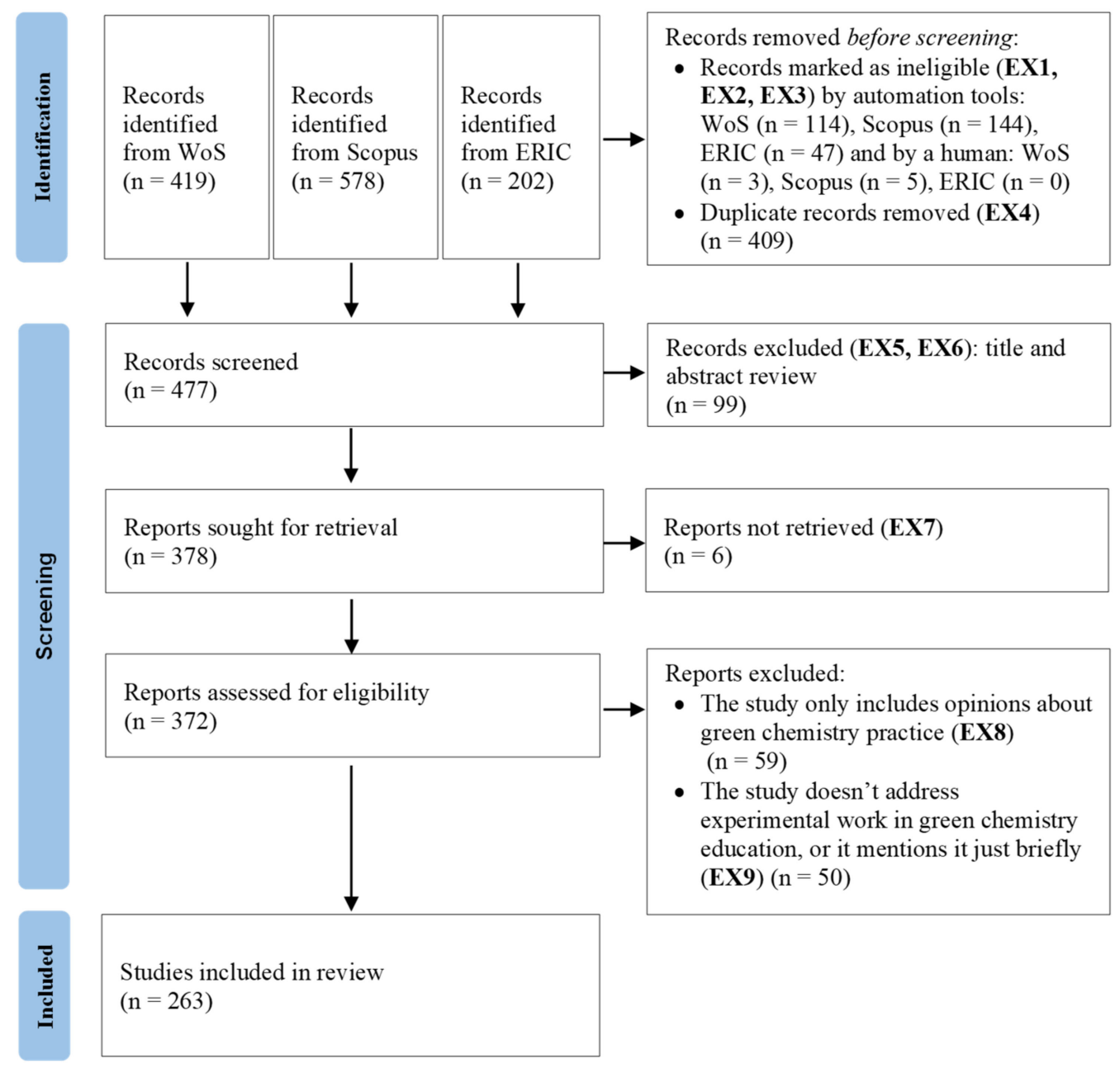

Figure 1. PRISMA 2020 flow diagram [60].

The corresponding table for all included papers $(n=263)$ in the systematic literature review can be found in the Appendix A (Table A1). The coding number of the paper and the electronic database from which it was extracted (all papers from Scopus [and duplicates in WoS and ERIC] = S; all papers from WoS [and duplicates in ERIC] = W; all papers from ERIC $=$ E) are also provided and follow the codification [66] used to identify specific papers to discuss the results of the analysis.

The following data were extracted from each paper: (1) field of chemistry, (2) type of paper, (3) purpose of the paper, (4) learning type, (5) educational level/target groups, and (6) green chemistry content (regarding green chemistry principles).

Two researchers (the authors of this paper) independently performed the systematic literature review following the established protocol using the same inclusion and exclusion criteria and descriptors. The authors compared and confirmed their findings. The degree of agreement on the inclusion of papers was $98 \%$. Disagreements were resolved by discussion and shared consensus.

\section{Results}

\subsection{What Are the Characteristics of the Reviewed Papers Published from 1995 to 2020?}

A total of 263 papers met the objectives of the study and the inclusion and exclusion criteria (Figure 1). The first identified paper that focused on experimental work from green chemistry perspectives was published in 2000 in the Journal of Chemical Education and addressed "an environmentally benign synthesis of adipic acid" aimed at organic instructors [67]. However, more intense research from green chemistry perspectives began in 2011 
and reached a peak in 2019 with 42 papers (duplicates excluded). More than half of all reviewed papers $(n=140)$ were published in the previous five years (2015-2020) (Figure 2).

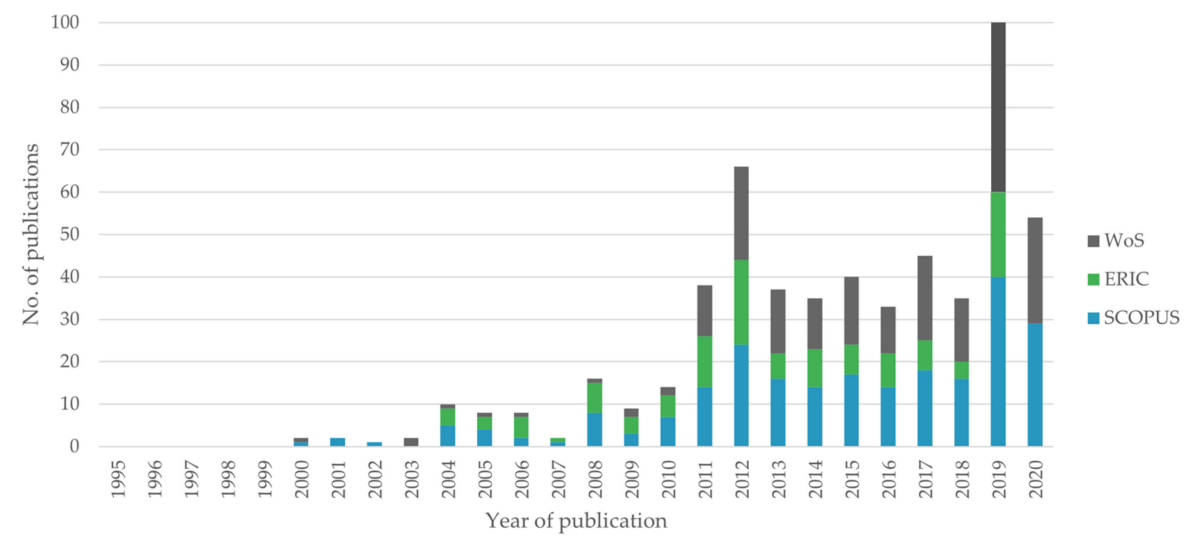

Figure 2. Grouping of publications by year and electronic database (WoS, ERIC, and Scopus) dealing with experimental work from green chemistry perspectives (Note: In Figure 2, the duplicate papers are not excluded.).

Table 2 lists the scientific journals in which papers addressing experimental work from green chemistry perspectives were published between 1995 and 2020. As can be seen from Table 2, the majority of papers $(n=200)$ were published in the Journal of Chemical Education. This finding is in agreement with Marques et al. [68], who noted that almost half of the scientific papers on the wider topic of green chemistry education in the WoS were published in the Journal of Chemical Education. Both studies suggest that this journal can be recognized as an important source for the dissemination of practices in educational settings in this field at the international level.

The remaining journals that published several articles addressing experimental work from green chemistry perspectives are: Green Chemistry Letters and Reviews $(n=8)$, Physical Sciences Reviews $(n=7)$, Chemistry Education Research and Practice $(n=5)$, Current Opinion in Green and Sustainable Chemistry $(n=4)$, Journal of Science Education $(n=3)$, Green Chemistry $(n=3)$, ACS Chemical Health and Safety $(n=2)$, ACS Symposium Series $(n=2)$, Quimica Nova $(n=2)$, and Research in Science $\mathcal{E}$ Technological Education $(n=2)$. In a further 25 journals, one paper on this topic was published (Table 2).

In Table 3 the reviewed papers are presented according to the "type of paper," e.g., literature review, experience report, or evaluation study. Thus, 17 review papers and 41 evaluation studies were identified. However, most of the research papers $(n=205)$ were experience reports that focused on the development and implementation of practical activities related to experimental work from green chemistry perspectives.

From green chemistry perspectives, the experimental work was mostly addressed in relation to organic chemistry $(n=150$, Table 4$)$. The integration of green chemistry into education was most notable in the context of optimizing organic syntheses, which was an aspect repeatedly highlighted in the literature [12,52]. As can be seen from Table 4, other papers addressed experimental work in general chemistry $(n=23)$, analytical chemistry $(n=21)$, inorganic chemistry $(n=15)$, chemistry $(n=12)$, polymer science $(n=10)$, physical chemistry $(n=9)$, environmental chemistry $(n=7)$, and some papers in other fields of chemistry $(n=16)$, which reflects the need for the introduction of green chemistry ideas into various fields of chemistry. 
Table 2. Scientific journals with papers published between 1995 and 2020 dealing with experimental work from a green chemistry perspective.

\begin{tabular}{|c|c|c|c|c|c|}
\hline Journal & Publisher & ISSN [e-ISSN] & 5-Year IF * & No. of Papers & Paper Code \\
\hline $\begin{array}{l}\text { Journal of Chemical } \\
\text { Education }\end{array}$ & $\begin{array}{l}\text { American Chemical } \\
\text { Society }\end{array}$ & $\begin{array}{c}0021-9584 \\
(1938-1328)\end{array}$ & 2.37 & 200 & $\begin{array}{c}\text { S1-S7, S9-S13, S15-S23, } \\
\text { S25-S36, S38-S42, S44-S47, } \\
\text { S49-S51, S55-S58, S60, S61, } \\
\text { S64-S66, S68-S74, S76-S82, } \\
\text { S84-S86, S88-S93, } \\
\text { S101-S108, S110 } \\
\text { S114-S123, S125, } \\
\text { S127-S135, S137, } \\
\text { S139-S143, S145, S146, } \\
\text { S148, S152-S154, S156, } \\
\text { S158-S167, S170, S171, } \\
\text { S173-S183, S185-S196, } \\
\text { S198, S200-S204, S206, } \\
\text { S208, S211-S214, } \\
\text { S216-S226, 1W, 3W, 7W, } \\
\text { 10W, 1E-19E }\end{array}$ \\
\hline $\begin{array}{l}\text { Green Chemistry } \\
\text { Letters and Reviews }\end{array}$ & Taylor and Francis Ltd. & $\begin{array}{c}1751-8253 \\
(1751-7192)\end{array}$ & 3.963 & 8 & $\begin{array}{c}\text { S53, S54, S168, S169, S184, } \\
2 \mathrm{~W}, 5 \mathrm{~W}, 6 \mathrm{~W}\end{array}$ \\
\hline $\begin{array}{c}\text { Physical Sciences } \\
\text { Reviews }\end{array}$ & De Gruyter & $\begin{array}{c}2365-659 X \\
(2365-659 X)\end{array}$ & 0.811 & 7 & $\begin{array}{l}\text { S14, S24, S48, S109, S136, } \\
\text { S144, S230 }\end{array}$ \\
\hline $\begin{array}{c}\text { Chemistry } \\
\text { Education Research } \\
\text { and Practice }\end{array}$ & $\begin{array}{l}\text { Ioannina University } \\
\text { School of Medicine }\end{array}$ & $\begin{array}{c}1109-4028 \\
(1756-1108)\end{array}$ & 2.57 & 5 & S8, S62, S98, S111, S210 \\
\hline $\begin{array}{c}\text { Current Opinion in } \\
\text { Green and } \\
\text { Sustainable } \\
\text { Chemistry }\end{array}$ & Elsevier BV & $2452-2236$ & 5.546 & 4 & S87, S52, S94, S197 \\
\hline $\begin{array}{l}\text { Journal of Science } \\
\text { Education }\end{array}$ & Taylor and Francis Ltd. & $\begin{array}{c}0950-0693 \\
(1464-5289)\end{array}$ & 2.302 & 3 & S43, S67, S207 \\
\hline Green chemistry & $\begin{array}{l}\text { Royal Society } \\
\text { of Chemistry }\end{array}$ & $\begin{array}{c}1463-9262 \\
(1463-9270)\end{array}$ & 9.905 & 3 & $\mathrm{~S} 232,9 \mathrm{~W}, 11 \mathrm{~W}$ \\
\hline $\begin{array}{l}\text { ACS Chemical } \\
\text { Health and Safety }\end{array}$ & $\begin{array}{l}\text { American Chemical } \\
\text { Society }\end{array}$ & $\begin{array}{c}1871-5532 \\
(1878-0504)\end{array}$ & 1.196 & 2 & S138, S199 \\
\hline $\begin{array}{c}\text { ACS Symposium } \\
\text { Series }\end{array}$ & $\begin{array}{l}\text { American Chemical } \\
\text { Society }\end{array}$ & $\begin{array}{c}0097-6156 \\
(1947-5918)\end{array}$ & 0.474 & 2 & S227, S228 \\
\hline Quimica Nova & $\begin{array}{c}\text { Sociedade Brasileira } \\
\text { de Quimica }\end{array}$ & $\begin{array}{c}0100-4042 \\
(1678-7064)\end{array}$ & 0.739 & 2 & S59, S155 \\
\hline $\begin{array}{c}\text { Research in Science } \\
\text { E Technological } \\
\text { Education }\end{array}$ & Taylor and Francis Ltd. & $\begin{array}{c}0263-5143 \\
(1470-1138)\end{array}$ & 1.764 & 2 & S75, S172 \\
\hline $\begin{array}{r}\text { Other journa } \\
\text { ACS applied mate } \\
\text { Engineering, An } \\
\text { Asia-Pacific Educatio } \\
\text { Chemistry-Didactic } \\
\text { Oggi, Educacion } \\
\text { Pharmaceutical Educ } \\
\text { Education, Journa } \\
\text { Macedonian Journal } \\
\text { for Education Social } \\
\text { Sustainability, Su } \\
\text { Chemistry, Waste I }\end{array}$ & $\begin{array}{l}\text { s with one identified pap } \\
\text { ials } \mathcal{E} \text { interfaces, ACS Ome } \\
\text { lytical and Bioanalytical Ch } \\
\text { Researcher, Asia-Pacific Fo } \\
\text {-Ecology-Metrology, Chem } \\
\text { Quimica, Environmental Ed } \\
\text { tion and Research, Internati } \\
\text { of Science Teacher Educatio } \\
\text { f Chemistry and Chemical } \\
\text { nd Technological Sciences, } \\
\text { tainable Chemistry and Pha } \\
\text { Ianagement, World Transac } \\
\text { Education. }\end{array}$ & $\begin{array}{l}\text { each (listed alpha } \\
\text {, ACS Sustainable } \\
\text { mistry, Applied Ma } \\
\text { tm on Science Learn } \\
\text { sChem, Chromatog } \\
\text { ation Research, Ind } \\
\text { al Journal of Sustai } \\
\text { Jurnal Pendidikan } \\
\text { gineering, Multidi } \\
\text { ish Journal of Envi } \\
\text { nacy, TrAC-Trend } \\
\text { ns on Engineering }\end{array}$ & $\begin{array}{l}\text { ically): } \\
\text { mistry and } \\
\text { als Today, } \\
\text { and Teaching, } \\
\text { hia, Chimica } \\
\text { Journal of } \\
\text { ility in Higher } \\
\text { Indonesia, } \\
\text { inary Journal } \\
\text { nental Studies, } \\
\text { Analytical } \\
\text { Technology }\end{array}$ & $\begin{array}{c}25 \text { (one in each } \\
\text { of the listed } \\
\text { journals) }\end{array}$ & $\begin{array}{l}\text { S149, S151, S112, S37, S150, } \\
\text { S96, S95, 4W, S157, S209, } \\
\text { S229, S205, S99, S233, S100, } \\
\text { S97, S126, S147, 8W, S215, } \\
\text { S124, S83, S113, S63, S231 }\end{array}$ \\
\hline
\end{tabular}


Table 3. Papers dealing with experimental work from green chemistry perspectives published between 1995 and 2020 according to the type of paper.

\begin{tabular}{ccc}
\hline Type of Paper & Frequency & Paper Code \\
\hline & & S1-S3, S5-S7, S9, S11, S14-S23, S26-S35, S37-S48, S49-S51, S55-S57, S59, S61-S74, S78-S86, \\
Experience report & 205 & S88-S92, S102-S108, S110, S112-S116, S119, S121-S125, S127-S132, S134-S136, S138, \\
& & S141-S143, S147, S149, S151-S156, S158-S166, S170, S171, S173-S175, S177-S182, S184, \\
& & S187-S196, S198-S202, S204-S209, S211-S214, S216-S233, 1W-4W, 6W, 9W, 10W, 11W, \\
Evaluation study & 41 & S4, S10, S13, S24, S25, S36, S58, S60, S75-S77, S93-S101, S117, S118, S120, S126, S133, S139, \\
Review & 17 & S140, S145, S146, S148, S167-S169, S172, S176, S183, S203, S210, 7W, 8W, 6E \\
Total & 263 &
\end{tabular}

Table 4. Papers dealing with experimental work from green chemistry perspectives published between 1995 and 2020 according to the field of chemistry.

\begin{tabular}{|c|c|c|}
\hline Field of Chemistry & Frequency ${ }^{*}$ & Paper Code \\
\hline Organic chemistry & 150 & $\begin{array}{l}\text { S1, S2, S4, S5, S7, S12, S16-S18, S20, S21, S23, S25, S27, S28, S33, S36, S38-S40, } \\
\text { S42, S44, S47, S49, S50, S52-S56, S59-S62, S64, S67-S74, S78-S82, S84, S85, } \\
\text { S90-S93, S102-S104, S108, S110, S114-S117, S120-S123, S125, S128, S131-S134, } \\
\text { S136, S137, S139, S141, S142, S144-S147, S151-S157, S162, S163, S165, S166, S170, } \\
\text { S174-S176, S178, S182, S183, S185-S187, S190, S191, S193-S195, S198, S201, } \\
\text { S203-S207, S210, S212-S214, S217, S219, S222-S224, S227-S232, 1W-6W, 9W, 10W, } \\
\text { 2E, 3E, 5E, 6E, 8E-12E, 14E, 16E, 17E }\end{array}$ \\
\hline General chemistry & 23 & $\begin{array}{c}\mathrm{S} 6, \mathrm{~S} 10, \mathrm{~S} 12, \mathrm{~S} 14, \mathrm{~S} 29, \mathrm{~S} 31, \mathrm{~S} 32, \mathrm{~S} 48, \mathrm{~S} 101, \mathrm{~S} 105, \mathrm{~S} 127, \mathrm{~S} 152, \mathrm{~S} 156, \mathrm{~S} 160, \mathrm{~S} 164 \\
\mathrm{~S} 172, \mathrm{~S} 173, \mathrm{~S} 192, \mathrm{~S} 198, \mathrm{~S} 216, \mathrm{~S} 220, \mathrm{~S} 226,18 \mathrm{E}\end{array}$ \\
\hline Analytical chemistry & 21 & $\begin{array}{l}\text { S3, S30, S36, S37, S58, S66, S75, S111, S113, S118, S151, S157, S160, S164, S187, } \\
\text { S202, S212, S221, S223, S209, 7E }\end{array}$ \\
\hline Inorganic chemistry & 15 & S9, S17, S36, S41, S46, S57, S65, S70, S76, S90, S149, S189, S196, S220, 7W \\
\hline Chemistry & 12 & S13, S94-S100, S109, S126, S150, S211 \\
\hline Polymer science & 10 & S35, S36, S88, S106, S107, S129, S140, S177, S200, S221 \\
\hline Physical chemistry & 9 & S36, S45, S159, S161, S172, S180, S206, S212, 13E \\
\hline Environmental chemistry & 7 & $\mathrm{~S} 11, \mathrm{~S} 51, \mathrm{~S} 63, \mathrm{~S} 112, \mathrm{~S} 143, \mathrm{~S} 148,19 \mathrm{E}$ \\
\hline Materials Science & 3 & $\mathrm{~S} 89, \mathrm{~S} 135, \mathrm{~S} 179$ \\
\hline Biochemistry & 2 & S188, S218 \\
\hline Interdisciplinary & 2 & S26, S208 \\
\hline Industrial chemistry & 1 & S34 \\
\hline Organic catalysis & 1 & S158 \\
\hline Electrochemistry & 1 & S124 \\
\hline Chemical technology & 1 & S225 \\
\hline Other & 5 & $\mathrm{~S} 15, \mathrm{~S} 19, \mathrm{~S} 119, \mathrm{~S} 130, \mathrm{~S} 233$ \\
\hline Not defined & 23 & $\begin{array}{l}\text { S8, S22, S24, S43, S77, S83, S86, S87, S138, S167, S168, S169, S171, S181, S184, } \\
\text { S197, S199, S215, 8W, 11W, 1E, 4E, 15E }\end{array}$ \\
\hline
\end{tabular}

Note: * Some reviewed papers describe or indicate implementation of experimental work from green chemistry perspectives for more than one field of chemistry.

\subsection{What Are the Main Purposes of the Reviewed Papers?}

The analysis of the presented systematic review attempts to provide an overview of the main purposes for integrating green chemistry into experimental work addressed in the papers (Table 5). The results show that most of the reviewed papers focus on the integration of green chemistry into traditional chemistry teaching $(n=228)$, e.g., with the optimization of experimental work in terms of green chemistry principles [70-77]. In a further 30 reviewed papers, the integration of green chemistry into the curriculum was mentioned, some also in the context of the main benefit of improving chemical safety. In addition, 31 papers addressed a strong synergy between chemical safety and green chemistry goals $[27,78-80]$. Some papers $(n=27)$ focus on integrating green chemistry metrics into traditional chemistry teaching [81], while others also compare traditional ex- 
perimental work to experimental work optimized with green chemistry principles [82-84]. This is particularly important given the debate in the literature about what is or is not green chemistry $[52,68]$. Researchers also indicated the scope of their papers in promoting green chemistry education $(n=24)$ and also by solving socio-environmental problems from green chemistry perspectives $(n=21)[22,85,86]$. The opportunity to promote systems thinking [87] ( $n=17)$ and life-cycle thinking [88] $(n=16)$ within green chemistry education was also highlighted to provide innovative solutions to current and future sustainability challenges. Other indicated purposes of the reviewed papers include developing green and sustainable products $(n=17)$, identifying green chemistry approaches in green chemistry education $(n=15)$, improving and creating teaching materials $(n=9)$, and developing green skills $(n=9)$. Some studies $(n=6)$ also presented the use of innovative didactic tools in teaching and learning about green chemistry $[89,90]$.

Table 5. Indicated purposes of papers dealing with experimental work from green chemistry perspectives published between 1995 and 2020.

\begin{tabular}{|c|c|c|}
\hline Purpose of Papers & Frequency * & Paper Code \\
\hline $\begin{array}{l}\text { Integrating GC into traditional } \\
\text { chemistry teaching }\end{array}$ & 228 & $\begin{array}{l}\text { S1-S12, S14-S20, S23-S25, S27-S42, S44-S51, S53-S62, S65, S67-S70, S72-S75, } \\
\text { S77-S97, S99-S142, S144-S149, S151-S166, S170-S199, S201-S207, S209, S213, } \\
\text { S217, S219, S224, S226, S228-S233, 1W-11W, 1E-5E, 7E-16E, 19E }\end{array}$ \\
\hline Fostering a culture of safety & 31 & $\begin{array}{c}\text { S1, S12, S35, S48, S76, S91, S109, S112, S118, S119, S126, S127, S131, S136-S138, } \\
\text { S140, S141, S144, S157, S162, S164, S165, S185, S195, S197, S198, S199, } \\
\text { S211, 8W, 16E }\end{array}$ \\
\hline Integrating GC into curriculum & 30 & $\begin{array}{l}\text { S10, S12, S41, S48, S51, S56, S76, S77, S83, S87, S109, S113, S119, S120, S124, S126, } \\
\text { S134, S137, S144, S157, S160, S165, S167, S171, S202, S223, S230, 6W, 8W, 7E }\end{array}$ \\
\hline $\begin{array}{l}\text { Integrating GC metrics into } \\
\text { traditional chemistry teaching }\end{array}$ & 27 & $\begin{array}{c}\text { S5, S38, S46, S52, S64, S66, S71, S83, S109, S115, S139, S145, S146, S167-S169, } \\
\text { S185, S193, S197, S203, S226, 2W, 7W, 1E, 4E, 6E, 17E }\end{array}$ \\
\hline $\begin{array}{l}\text { Promoting green } \\
\text { chemistry education }\end{array}$ & 24 & $\begin{array}{c}\text { S2, S13, S14, S26, S27, S37, S43, S47, S54, S57, S66, S97, S99, S109, S143, S151, } \\
\text { S152, S176, S186, S199, S203, S200, S233, W7 }\end{array}$ \\
\hline Socio-scientific approach & 21 & $\begin{array}{c}\text { S4, S24, S26, S96, S107, S143, S149, S157, S161, S164, S165, S171-S173, S176, S180, } \\
\text { S197, S199, S200, S204, S226 }\end{array}$ \\
\hline $\begin{array}{l}\text { Development of } \\
\text { systems thinking }\end{array}$ & 17 & $\begin{array}{c}\text { S10, S12, S26, S36, S45, S51, S87, S101, S115, S116, S129, S139, S143, S156, S179, } \\
\text { S204, S226 }\end{array}$ \\
\hline $\begin{array}{l}\text { Development of green and } \\
\text { sustainable products }\end{array}$ & 17 & $\begin{array}{l}\text { S2, S21, S22, S24, S28, S35, S63, S106, S107, S130, S150, S153, S158, S177, S200, } \\
\text { S212, S227 }\end{array}$ \\
\hline $\begin{array}{l}\text { Development of } \\
\text { life-cycle thinking }\end{array}$ & 16 & S2, S10, S20, S36, S57, S62, S76, S129, S149, S179, S185, S216, S225, S226, 2W, 4E \\
\hline $\begin{array}{l}\text { Identifying GC approaches for } \\
\text { GC education }\end{array}$ & 15 & S8, S13, S26, S51, S74, S75, S98, S109, S113, S126, S157, S197, S208, S210, S222 \\
\hline $\begin{array}{l}\text { Improvement and creation of } \\
\text { teaching material }\end{array}$ & 9 & S37, S67, S113, S135, S197, S218, S220, S221, S223 \\
\hline Development of green skills & 9 & S1, S2, S24, S133, S141, S146, S161, S214, 19E \\
\hline Use of innovative didactic tools & 6 & S34, S62, S74, S87, S195, S197 \\
\hline Promoting chemistry education & 1 & S27 \\
\hline Other (informative) & 1 & S215 \\
\hline
\end{tabular}

* Note: Some reviewed papers describe or indicate the implementation of experimental work from green chemistry perspectives for more than one field of chemistry.

\subsection{Which Learning Type Is Predominant in the Reviewed Papers?}

The learning type category (Table 6) sought to review the learning types that were formulated and/or discussed in each paper. In this sense, we used Laurillard's concept of learning types derived from her "conversational framework" model, i.e., acquisition, inquiry, practice, discussion, collaboration, and production [91]. As can be seen from Table 6, learning with practice predominates $(n=158)$ in the reviewed papers and most papers describe a laboratory setting in organic chemistry. 
Table 6. Papers dealing with experimental work from green chemistry perspectives published between 1995 and 2020 according to the predominant learning type.

\begin{tabular}{|c|c|c|}
\hline Learning Type & Frequency * & Paper Code \\
\hline Learning through practice & 158 & $\begin{array}{l}\text { S2-S5, S7, S9, S13-S15, S33, S35, S37-S42, S44, S45, S49, S50, S58, S63, S65, S68, S71, } \\
\text { S74, S77, S79, S85, S89, S91, S92, S95-S97, S102, S104, S105, S112, S114, S115, S117, } \\
\text { S118, S122, S123, S125-S127, S129, S131, S132, S134-S137, S139-S142, S144, S146, } \\
\text { S149-S156, S158, S159, S161-S165, S167-S172, S174-S181, S183-S196, S199-S207, } \\
\text { S209, S211, S213, S214, S216-S225, S227-S229, S232, S233, 1W-4W, 7W-9W, 11W, } \\
\text { 1E-9E, 11E-15E, 17E, 18E, 19E }\end{array}$ \\
\hline Learning through inquiry & 86 & $\begin{array}{l}\text { S1, S6, S10, S11, S16-S32, S34, S36, S46, S47, S52, S55-S57, S59-S62, S64, S66, S67, } \\
\text { S69, S70, S72, S73, S76, S78, S80-S84, S88, S90, S93, S94, S101, S103, S106-S108, } \\
\text { S110, S116, S119-S121, S124, S128, S130, S133, S143, S145, S147, S148, S160, S166, } \\
\text { S173, S178, S182, S183, S198, S208, S212, S226, S230, S231, 5W, 6W, 10W, 10E, 16E }\end{array}$ \\
\hline Learning through collaboration & 15 & S2, S6, S26, S31, S34, S62, S69, S73, S74, S146, S176, S178, S183, S195, S231 \\
\hline Learning through discussion & 13 & S1, S13, S15, S20, S22, S26, S31, S41, S46, S115, S141, S172, S195 \\
\hline Learning through acquisition & 2 & S86, S163 \\
\hline Integrated teaching & 1 & S210 \\
\hline Other & 2 & $\mathrm{~S} 8, \mathrm{~S} 43$ \\
\hline Not defined/Not relevant & 16 & $\begin{array}{l}\text { S12, S48, S51, S53, S54, S87, S98, S99, S100, S109, S111, S113, S138, S157, } \\
\text { S197, S215 }\end{array}$ \\
\hline
\end{tabular}

* Note: Some reviewed papers refer to more than one learning type.

With the intention to support students' development of high-order thinking skills in the laboratory, several papers identified the use of inquiry-based learning $(n=86)$. Learning through collaboration, sometimes related to problem- and project-based learning was mentioned in some papers $(n=15)$. Similarly, learning through discussion was highlighted $(n=13)$. A minority of papers $(n=2)$ were categorized in the framework of acquisition, e.g., experimental work optimized from green chemistry perspectives that can be performed as a demonstration. From some articles $(n=16)$, it was not possible to identify the learning type because they were, e.g., review papers or general descriptions of ideas for how green chemistry could be integrated into experimental work.

\subsection{What Education Levels Do the Reviewed Papers Focus on?}

According to the data presented in Table 7 , most studies refer to tertiary education students in nonpedagogical study programs $(n=224)$. These students are typically older than 18 years. Fewer papers refer to secondary education $(n=33)$ with students aged $12-18$ years and primary education $(n=2)$ with students aged $6-11$ years. Some papers $(n=16)$ broadened their scope by proposing targeting students at two education levels (mainly tertiary and secondary) and several papers $(n=8)$ did not mention the target groups or the education level, which could indicate the less evident scope of these articles for the integration of green chemistry perspectives in education [68].

As can be seen from Table 7, only 12 papers targeted the teacher population. Preservice teachers (tertiary education-pedagogical studies) were addressed in nine articles. Some of these articles described examples of the integration of green chemistry experimental work $[39,83,92-97]$, whereas others evaluated activities for integration of green chemistry into experimental work $[95,97,98]$. The incorporation of green chemistry experiments into the education of pre-service teachers was recognized as a way to promote the development of students' pro-environmental attitudes, values, knowledge, and motivation [39,95-97]. On the other hand, in-service teachers were specifically mentioned in only three papers. In this regard, in-service university teachers were supported with materials related to optimization of the use of solvents (green chemistry principle 5) in organic experiments in courses for undergraduate students [56,57] and only one article addressed [99] in-service teacher training focused on green chemistry experiments for secondary school teachers. 
Table 7. Papers dealing with experimental work from green chemistry perspectives published between 1995 and 2020 according to the education level they addressed.

\begin{tabular}{|c|c|c|}
\hline Education Level & Frequency * & Paper Code \\
\hline $\begin{array}{l}\text { Tertiary education-nonpedagogical } \\
\text { studies (19-years old) }\end{array}$ & 224 & $\begin{array}{l}\text { S1-S12, S14-S21, S23-S25, S29, S30, S32-S36, S38-S42, S44-S49, S51, } \\
\text { S52, S55-S59, S61, S64, S65, S67-S82, S84, S85, S88-S93, S101-S105, } \\
\text { S108, S110, S112-S125, S127-S139, S141, S142, S144-S146, S148-S167, } \\
\text { S169, S170, S172-S183, S185-S188, S190-S196, S198, S201-S209, } \\
\text { S211-S214, S216-S219, S221-S226, S228, S229, S231-S233 1W-3W, 5W, } \\
\text { 6W, 8W-10W, 1E-5E, 7E-14E, 16E, 17E, 19E }\end{array}$ \\
\hline Secondary education (12-18 years old) & 33 & $\begin{array}{c}\text { S13, S22, S28, S31, S32, S50, S60, S62, S83, S86, S95, S96, S106, S107, } \\
\text { S111, S114, S126, S140, S143, S147, S167, S184, S189, S198, S199, S200, } \\
\text { S210, S220, S230, 4W, 6E, 15E, 18E }\end{array}$ \\
\hline $\begin{array}{l}\text { Tertiary education-pedagogical } \\
\text { studies (19-years old) }\end{array}$ & 9 & S26, S27, S50, S66, S97, S98, S99, S100, 7W \\
\hline Primary education (6-11 years old) & 2 & $\mathrm{~S} 43, \mathrm{~S} 86$ \\
\hline In-service teacher education & 3 & S53, S54, S94 \\
\hline All levels & 1 & S87 \\
\hline Not defined & 8 & S37, S63, S109, S168, S171, S197, S227, 11W \\
\hline
\end{tabular}

* Note: Some reviewed papers address more than one education level and target groups.

\subsection{Which Green Chemistry Principles Are Addressed in the Reviewed Papers?}

A large number of papers included in the systematic literature review refer directly or indirectly to the 12 Principles of Green Chemistry, which is not surprising because the principles are a foundation of green chemistry. The results of the analysis are presented in Table 8, where the most frequently addressed green chemistry principles are listed first, while the least frequently addressed principles are shown at the bottom of the table.

Table 8 shows that a considerable number of papers deal with the substitution of solvents and other auxiliary substances (green chemistry principle $5, n=107$ ), waste prevention (green chemistry principle $1, n=89$ ), and the use of catalysts (green chemistry principle $9, n=77$ ). Some papers described the optimization of experimental work by also considering the following principles: design for energy efficiency (green chemistry principle $6, n=71$ ), use of renewable feedstock (green chemistry principle $7, n=65$ ), atom economy (green chemistry principle $2, n=64$ ), less hazardous synthesis (green chemistry principle $3, n=62$ ), inherently benign chemistry for accident prevention (green chemistry principle 12, $n=51$ ), design for degradation (green chemistry principle 10, $n=30$ ), and reduction of derivatives (green chemistry principle $8, n=17$ ), although to a lesser extent. In the reviewed papers, the principles of designing safer chemicals (green chemistry principle $4, n=14$ ) and real-time analysis for pollution prevention (green chemistry principle $11, n=10$ ) were the least covered, which is not surprising given that these two principles are usually excluded from teaching experiments because laboratory work does not involve the production of new products $[83,100]$.

It is interesting to note that more than half of the papers $(58.94 \%)$ considered one $(n=49)$, two $(n=58)$, or three $(n=48)$ green chemistry principles, and only some $(4.56 \%)$ considered experimental work from green chemistry perspectives more holistically in terms of the many features that must be considered when the "greenness" of a chemical reaction is discussed. In this context, some papers addressed ten $(n=7)$, eleven $(n=2)$, or all green chemistry principles $(n=4$, Table 9$)$. 
Table 8. Number of papers dealing with experimental work from green chemistry perspectives published between 1995 and 2020 according to the 12 green chemistry principles that they address.

\begin{tabular}{|c|c|c|}
\hline Green Chemistry Principle & Frequency * & Paper Code \\
\hline $\begin{array}{l}\text { GC Principle 5: Safer } \\
\text { solvents \& auxiliaries. }\end{array}$ & 107 & $\begin{array}{l}\text { S2, S9, S10, S13, S19, S20, S23, S25, S30, S37-S42, S44, S47, S53, S54, S58, } \\
\text { S61, S62, S64-S68, S74, S78-S80, S82, S84-S86, S90-S92, S103, S106, S108, } \\
\text { S110, S112, S116, S117, S122, S123, S125, S128, S130, S132, S134-S137, } \\
\text { S139, S141, S145, S147, S153-S156, S160-S162, S165-S167, S169, S170, } \\
\text { S176-S180, S182, S183, S186, S190, S191, S193, S198, S201, S203, S204, } \\
\text { S210, S222, S226, S228, S229, S232, S233, 2W, 3W, 5W-7W, 10W, 1E, 2E, } \\
\text { 4E, 6E, 8E, 9E, 11E, 17E }\end{array}$ \\
\hline GC Principle 1: Prevent waste. & 89 & $\begin{array}{c}\text { S10, S14, S18-S20, S32, S33, S38, S41, S49, S53, S55, S56, S62, S64, S66, } \\
\text { S67, S69-S71, S74, S82, S91, S93, S102-S105, S110, S112, S117, S118, S120, } \\
\text { S121, S124, S126, S128-S130, S133, S135-S141, S144-S146, S149, S153, } \\
\text { S156, S163, S165, S167-S169, S176, S184, S191, S193, S194, S199, S200, } \\
\text { S204, S210, S222, S226-S228, 3W, 5W-9W, 11W, 1E-3E, 6E-8E, 10E, 12E, } \\
\text { 16E, 18E, 19E }\end{array}$ \\
\hline GC Principle 9: Catalysis. & 77 & $\begin{array}{l}\text { S9, S16-S21, S35, S36, S40, S41, S43, S44, S46, S47, S56, S60, S61, S64, S66, } \\
\text { S69, S74, S78, S80, S81, S89, S90, S93, S103, S114-S117, S120, S121, S125, } \\
\text { S130, S134, S136, S137, S144, S146, S150, S156, S165, S167, S169, S171, } \\
\text { S177, S181, S186, S187, S189, S193, S196, S200, S203, S204, S210, S221, } \\
\text { S223, S226, S233, 1W-5W, 7W, 9W, 10W, 3E, 5E, 6E, 14E, 17E, 19E }\end{array}$ \\
\hline $\begin{array}{l}\text { GC Principle 6: Design for } \\
\text { energy efficiency. }\end{array}$ & 71 & $\begin{array}{c}\text { S2, S5, S7, S9, S10, S19, S20, S22, S25, S30, S37, S39, S43, S49, S53, S54, } \\
\text { S61, S64, S66, S67, S74, S85, S90, S93, S103, S117, S120, S127, S130, S132, } \\
\text { S136, S137, S139, S141, S142, S144, S146, S147, S155, S158, S166, S167, } \\
\text { S169, S172, S175, S181, S182, S184, S190, S192-S194, S202, S203, S205, } \\
\text { S210, S226, S227, S229, S233, 1W, 5W, 6W, 7W, 8W, 10W, 2E, 3E, 4E, 6E, } \\
\text { 10E, 19E }\end{array}$ \\
\hline $\begin{array}{l}\text { GC Principle 7: Use of } \\
\text { renewable feedstock. }\end{array}$ & 65 & $\begin{array}{c}\text { S2, S10, S13, S19-S24, S28-S30, S59, S63, S64, S66, S74, S89, S91, S93, S98, } \\
\text { S103, S106, S107, S117, S118, S120, S126, S129, S133, S136, S141, S149, } \\
\text { S156, S158, S160, S167, S169, S171, S173, S177, S179, S184-S187, S189, } \\
\text { S192, S200, S203, S204, S210, S226, S230, 2W, 4W, 5W-7W, 9W, 5E, 6E, } \\
\text { 13E, 18E }\end{array}$ \\
\hline GC Principle 2: Atom economy. & 64 & $\begin{array}{c}\text { S2, S5, S10, S14, S18-S20, S25, S29, S32, S38, S47, S52, S62, S64, S66, S67, } \\
\text { S70, S71, S74, S78, S82, S90, S103, S110, S115, S120, S121, S128, S130, } \\
\text { S133, S136, S137, S139, S145, S146, S167-S169, S182, S192-S194, } \\
\text { S203-S205, S210, S219, S222, S226-S228, 1W, 2W, 5W-7W, 9W, 10W, 4E, } \\
\text { 6E, 8E, 12E, 17E }\end{array}$ \\
\hline $\begin{array}{l}\text { GC Principle 3: Less } \\
\text { hazardous synthesis. }\end{array}$ & 62 & $\begin{array}{c}\text { S2, S10, S19-S21, S25, S29, S31, S33, S38, S45, S64, S66, S69, S74, S88, S92, } \\
\text { S103-S105, S108, S110-S112, S117, S118, S121, S128, S130, S131, S136, } \\
\text { S137, S139, S141, S144, S147, S152, S154, S164, S165, S167, S169, S174, } \\
\text { S180, S181, S185, S188, S198, S210, 5W, 7W, 8W, 10W, 11W, 4E, 6E, } \\
\text { 10E-12E, 15E, 16E, 18E }\end{array}$ \\
\hline $\begin{array}{l}\text { GC Principle 12: Inherently benign } \\
\text { chemistry for accident prevention. }\end{array}$ & 51 & $\begin{array}{c}\text { S2, S19, S20, S30, S31, S33, S35, S64, S66, S74, S91, S92, S103, S112, S118, } \\
\text { S126, S127, S131, S134-S141, S144, S147, S152, S162-S167, S169, S174, } \\
\text { S176, S198, S199, S202, S210, S226, 5W, 7W, 8W, 10W, 2E, 6E, 8E, } \\
\text { 11E, 16E }\end{array}$ \\
\hline $\begin{array}{l}\text { GC Principle 10: Design } \\
\text { for degradation. }\end{array}$ & 30 & $\begin{array}{l}\text { S2, S10, S13, S19, S20, S23, S30, S35, S64, S66, S74, S91, S103, S106, S107, } \\
\text { S111, S120, S144, S160, S167, S169, S177, S179, S186, S200, S210, S226, } \\
\text { 5W, 7W, 6E }\end{array}$ \\
\hline GC Principle 8: Reduce derivatives. & 17 & $\begin{array}{l}\text { S19, S20, S64, S66, S74, S103, S120, S139, S162, S167, S169, S187, S210, } \\
\text { S226, 5W, 7W, 6E }\end{array}$ \\
\hline GC Principle 4: Design safer chemicals. & 14 & $\mathrm{~S} 2, \mathrm{~S} 10, \mathrm{~S} 14, \mathrm{~S} 17, \mathrm{~S} 19, \mathrm{~S} 20, \mathrm{~S} 32, \mathrm{~S} 103, \mathrm{~S} 119, \mathrm{~S} 139, \mathrm{~S} 192, \mathrm{~S} 210, \mathrm{~S} 226,8 \mathrm{~W}$ \\
\hline $\begin{array}{l}\text { GC Principle 11: Real-time analysis for } \\
\text { pollution prevention. }\end{array}$ & 10 & S10, S19, S20, S58, S103, S147, S167, S169, S210, 10W \\
\hline General & 21 & $\begin{array}{c}\text { S72, S73, S75, S83, S143, S148, S151, S159, S195, S206, S207, S209, S211, } \\
\text { S212, S214, S216, S217, S218, S220, S224, S225 }\end{array}$ \\
\hline Not defined specifically & 33 & $\begin{array}{l}\text { S1, S3, S4, S6, S8, S11, S12, S15, S26, S27, S34, S48, S50, S51, S57, S76, S77, } \\
\text { S87, S94-S97, S99-S101, S109, S113, S157, S197, S208, S213, S215, S231 }\end{array}$ \\
\hline
\end{tabular}


Table 9. Number of papers dealing with experimental work from green chemistry perspectives published between 1995 and 2020 according to the number of green chemistry principles they address.

\begin{tabular}{|c|c|c|}
\hline $\begin{array}{c}\text { No. of Green Chemistry Principles } \\
\text { Addressed in the Papers }\end{array}$ & Frequency & Paper Code \\
\hline 2 & 58 & $\begin{array}{l}\text { S5, S17, S22, S31, S37, S39, S40, S43, S44, S49, S54, S56, S58, S70, S71, S80, } \\
\text { S85, S89, S104, S105, S107, S108, S111, S115, S116, S125, S127, S129, S131, } \\
\text { S132, S138, S140, S149, S152-S155, S158, S163, S164, S166, S168, S171, S174, } \\
\text { S180, S185, S189-S191, S199, S202, S205, S229, S233, 4W, 11W, 1E, 5E }\end{array}$ \\
\hline 1 & 49 & $\begin{array}{l}\text { S7, S16, S24, S28, S36, S42, S45, S46, S52, S55, S59, S60, S63, S65, S68, S79, } \\
\text { S81, S84, S86, S88, S98, S102, S114, S119, S122-S124, S142, S150, S161, S170, } \\
\text { S172, S173, S175, S178, S183, S188, S196, S201, S219, S221, S223, S230, S232, } \\
\text { 7E, 9E, 13E-15E }\end{array}$ \\
\hline 3 & 48 & $\begin{array}{c}\text { S9, S13, S14, S18, S21, S23, S29, S32, S33, S35, S41, S47, S53, S61, S62, S69, } \\
\text { S78, S82, S92, S106, S126, S133-S135, S145, S160, S162, S176, S179, S181, } \\
\text { S182, S184, S187, S194, S198, S222, S227, S228, 1W, 3W, 3E, 10E-12E, } \\
\text { 16E-19E }\end{array}$ \\
\hline 4 & 21 & $\begin{array}{c}\text { S25, S38, S67, S90, S93, S110, S112, S118, S121, S128, S146, S156, S177, } \\
\text { S186, S192, S200, 2W, 9W, 2E, 4E, 8E }\end{array}$ \\
\hline 5 & 9 & S30, S91, S147, S165, S193, S203, S204, 6W, 8W \\
\hline 10 & 7 & S64, S66, S74, S226, 5W, 7W, 6E \\
\hline 6 & 4 & $\mathrm{~S} 117, \mathrm{~S} 130, \mathrm{~S} 141, \mathrm{~S} 144$ \\
\hline 12 & 4 & $\mathrm{~S} 19, \mathrm{~S} 20, \mathrm{~S} 103, \mathrm{~S} 210$ \\
\hline 7 & 3 & S120, S137, 10W \\
\hline 8 & 3 & S2, S136, S139 \\
\hline 11 & 2 & S167, S169 \\
\hline 9 & 1 & S10 \\
\hline General & 21 & $\begin{array}{c}\text { S72, S73, S75, S83, S143, S148, S151, S159, S195, S206, S207, S209, S211, } \\
\text { S212, S214, S216-S218, S220, S224, S225 }\end{array}$ \\
\hline Not defined specifically & 33 & $\begin{array}{c}\text { S1, S3, S4, S6, S8, S11, S12, S15, S26, S27, S34, S48, S50, S51, S57, S76, S77, } \\
\text { S87, S94-S97, S99, S100, S101, S109, S113, S157, S197, S208, S213, } \\
\text { S215, S231 }\end{array}$ \\
\hline Total & 263 & \\
\hline
\end{tabular}

\section{Discussion and Conclusions}

\subsection{Key Findings and Implications}

This systematic literature review was conducted to provide an overview and insight into the research literature on laboratory experimental work related to green chemistry to support quality education by engaging students in experimental activities according to the fourth SDG from the Agenda 2030 framework. In order to facilitate the development of this important topic for future science education, the review aimed to derive information on the purposes for implementation of green chemistry in science education experimental work at all education levels and how these learning activities are predominantly performed. The novelty of the present paper is its attempt to reach a holistic perspective by involving all fields of chemistry, all education levels, and the 12 green chemistry principles from the previous 25 years of literature. Special attention was given to green chemistry education in relation to experimental work, addressing both pre- and in-service teachers.

For the purposes of this paper, a total of 263 papers resulting from the literature review following the 2020 PRISMA guidelines were analyzed to answer the set objectives and proposed research questions.

The results indicate that from 2011 onwards, there was a significant wave of publication of scientific papers about the implementation of green chemistry in laboratory experimental work, especially in the form of experience reports, which point to many examples of good teaching practices. This finding is consistent with the increased number of publications in the wider field targeting green chemistry [68]. The primary field of 
chemistry covered in the papers is organic chemistry, as also described in the previous literature on the subject [12,52]. Over the years, the reviewed literature has responded to the need to develop educational materials for other fields of chemistry, particularly analytical, environmental, and physical chemistry. In doing so, many researchers $[68,96]$ have pointed out the need to integrate green chemistry into existing curricula and teaching materials.

The results of the literature review suggest that updating chemistry teaching and learning with laboratory experimental work optimized from green chemistry perspectives simultaneously provides a safer approach to chemistry and ensures a safer environment by minimizing exposure to potentially hazardous chemicals and reducing the generated waste. Aubrecht et al. [27] pointed out the importance of teaching chemical safety by recognizing a significant overlap between reflection on the 12 green chemistry principles and the RAMP paradigm (recognize hazards, assess the risks of hazards, minimize the risks of hazards, and prepare for emergencies) [80].

Regarding the use of green chemistry in laboratory experimental work in science education at different education levels, our study revealed that it is used much more frequently in tertiary education compared with secondary and primary education. This finding is consistent with other recent studies that emphasize the need for novel activities, experiments, and case studies [24] in secondary and primary education, and highlight that incorporating green chemistry concepts into all education levels from primary to tertiary could be of great benefit to education as a whole [12,52]. Moreover, the present study also indicates the lack of research regarding the implementation of green chemistry in pre- and in-service teacher education.

The 12 green chemistry principles were referred to directly or indirectly in the reviewed papers. The results show that some of the green chemistry principles are predominantly used in the optimization of experimental work, e.g., the substitution of solvents and other auxiliary substances (green chemistry principle 5), waste prevention (green chemistry principle 1), and the use of catalysts (green chemistry principle 9). When analyzing the number of green chemistry principles addressed in each reviewed paper in the systematic literature review, it can be seen that most papers target one to three principles. Although not all principles were considered in most cases, it is important to keep in mind that even the application of a single green chemistry principle can make a big difference in experimental work. Therefore, the number of green chemistry principles involved should not be understood as just "all or nothing," but rather a striving for "the more, the better." It is important to develop students' green chemistry skills by asking simple questions, such as (1) "What is green about the experiment?"; (2) "What is not green?" and (3) "How could the experiment be optimized to be greener?" [12,52].

As a lack of studies on the integration of green chemistry principles into laboratory experimental work in secondary and primary education was identified, it would be beneficial to devote more attention to these education levels in the future. For example, it would be very valuable to develop teaching materials to support primary and secondary teachers in introducing green chemistry experimental work in their classes. Due to the crucial role of teachers in achieving the fourth SDG from the 2030 Agenda, special emphasis should be given to pre- and in-service teacher education, including didactical courses and corresponding teaching materials dealing with various possibilities for implementation of experimental work from green chemistry perspectives into the educational process at all education levels.

\subsection{Limitations}

The recently updated PRISMA guidelines were followed in this systematic literature review to make the results replicable and scientifically adequate. Three electronic databases (Scopus, WoS, and ERIC) were used in an attempt to identify as many eligible studies as possible to provide the broadest overview of laboratory experimental work related to green chemistry. However, by selecting only three electronic databases, potentially relevant publications may have been overlooked due to bias in the selection of databases or in 
the search terms used to identify eligible studies. In addition, review papers are usually limited by publication bias [101]. Furthermore, our systematic literature review is subject to language bias, as only English-language papers were included in the analysis.

Author Contributions: All authors have contributed equally. All authors have read and agreed to the published version of the manuscript.

Funding: The authors acknowledge the financial support from the Slovenian Research Agency (related to project No. J5-9328).

Institutional Review Board Statement: Not applicable.

Informed Consent Statement: Not applicable.

Data Availability Statement: The nature of the study (review) already implies in itself unique and complementary material. There is no need to attach further material.

Acknowledgments: We would like to express our sincere appreciation to the reviewers and editors.

Conflicts of Interest: The authors declare no conflict of interest. 


\section{Appendix A}

Table A1. Papers included in systematic literature review.

\begin{tabular}{|c|c|c|c|c|c|}
\hline Paper Code & Author(s) & Year & Name of Journal & Title & Ref. \\
\hline S1 & Abraham, L.; Stachow, L; Du, H. & 2020 & Journal of Chemical Education & $\begin{array}{l}\text { Cinnamon Oil: An Alternate and Inexpensive Resource for } \\
\text { Green Chemistry Experiments in Organic Chemistry } \\
\text { Laboratory }\end{array}$ & [42] \\
\hline S2 & Abraham, L. & 2020 & Journal of Chemical Education & A Green Nucleophilic Aromatic Substitution Reaction & [102] \\
\hline S3 & $\begin{array}{l}\text { Alberich, A.; Serrano, N.; Díaz-Cruz, J.M.; } \\
\text { Ariño, C.; Esteban, M. }\end{array}$ & 2013 & Journal of Chemical Education & $\begin{array}{l}\text { Substitution of mercury electrodes by bismuth-coated } \\
\text { screen-printed electrodes in the determination of quinine in } \\
\text { tonic water }\end{array}$ & [103] \\
\hline S5 & Alwaseem, H.; Donahue, C.J.; Marincean, S. & 2014 & Journal of Chemical Education & Catalytic transfer hydrogenation of castor oil & [105] \\
\hline S6 & $\begin{array}{l}\text { Amaris, Z.N.; Freitas, D.N.; Mac, K.; Gerner, } \\
\text { K.T.; Nameth, C.; Wheeler, K.E. }\end{array}$ & 2017 & Journal of Chemical Education & $\begin{array}{l}\text { Nanoparticle Synthesis, Characterization, and Ecotoxicity: } \\
\text { A Research-Based Set of Laboratory Experiments for a } \\
\text { General Chemistry Course }\end{array}$ & [106] \\
\hline S7 & $\begin{array}{l}\text { Amin, S.; Barnes, A.; Buckner, C.; Jones, J.; } \\
\text { Monroe, M.; Nurmomade, L.; Pinto, T.; } \\
\text { Starkey, S.; Agee, B.M.; Crouse, D.J.; } \\
\text { Swartling, D.J. }\end{array}$ & 2015 & Journal of Chemical Education & $\begin{array}{l}\text { Diels-alder reaction using a solar irradiation heat source } \\
\text { designed for undergraduate organic chemistry laboratories }\end{array}$ & [107] \\
\hline S8 & Andraos, J.; Dicks, A.P. & 2012 & Chemistry Education Research and Practice & $\begin{array}{l}\text { Green chemistry teaching in higher education: A review of } \\
\text { effective practices }\end{array}$ & [12] \\
\hline S9 & $\begin{array}{l}\text { Armstrong, C.; Burnham, J.A.J.; Warminski, } \\
\text { E.E. }\end{array}$ & 2017 & Journal of Chemical Education & $\begin{array}{l}\text { Combining Sustainable Synthesis of a Versatile Ruthenium } \\
\text { Dihydride Complex with Structure Determination Using } \\
\text { Group Theory and Spectroscopy }\end{array}$ & [108] \\
\hline S10 & $\begin{array}{l}\text { Armstrong, L.B.; Rivas, M.C.; Zhou, Z.; Irie, } \\
\text { L.M.; Kerstiens, G.A.; Robak, M.T.; Douskey, } \\
\text { M.C.; Baranger, A.M. }\end{array}$ & 2019 & Journal of Chemical Education & $\begin{array}{l}\text { Developing a Green Chemistry Focused General Chemistry } \\
\text { Laboratory Curriculum: What Do Students Understand } \\
\text { and Value about Green Chemistry? }\end{array}$ & {$[28]$} \\
\hline S11 & $\begin{array}{l}\text { Arrebola, J.C.; Rodríguez-Fernández, N.; } \\
\text { Caballero, Á. }\end{array}$ & 2020 & Journal of Chemical Education & $\begin{array}{l}\text { Decontamination of Wastewater Using Activated Biochar } \\
\text { from Agricultural Waste: A Practical Experiment for } \\
\text { Environmental Sciences Students }\end{array}$ & [109] \\
\hline
\end{tabular}


Table A1. Cont.

\begin{tabular}{|c|c|c|c|c|c|}
\hline Paper Code & Author(s) & Year & Name of Journal & Title & Ref. \\
\hline S12 & $\begin{array}{l}\text { Aubrecht, K.B.; Bourgeois, M.; Brush, E.J.; } \\
\text { Mackellar, J.; Wissinger, J.E. }\end{array}$ & 2019 & Journal of Chemical Education & $\begin{array}{l}\text { Integrating Green Chemistry in the Curriculum: Building } \\
\text { Student Skills in Systems Thinking, Safety, and } \\
\text { Sustainability }\end{array}$ & [27] \\
\hline S13 & $\begin{array}{l}\text { Aubrecht, K.B.; Padwa, L.; Shen, X.; } \\
\text { Bazargan, G. }\end{array}$ & 2015 & Journal of Chemical Education & $\begin{array}{l}\text { Development and implementation of a series of laboratory } \\
\text { field trips for advanced high school students to connect } \\
\text { chemistry to sustainability }\end{array}$ & [110] \\
\hline S14 & Bachofer, S.J.; Lingwood, M.D. & 2019 & Physical Sciences Reviews & $\begin{array}{l}\text { A green determination of an equilibrium constant: teaching } \\
\text { new skills }\end{array}$ & [111] \\
\hline S15 & $\begin{array}{l}\text { Bailey, A.; Andrews, L.; Khot, A.; Rubin, L.; } \\
\text { Young, J.; Allston, T.D.; Takacs, G.A. }\end{array}$ & 2015 & Journal of Chemical Education & $\begin{array}{l}\text { Hydrogen storage experiments for an undergraduate } \\
\text { laboratory course-clean energy: Hydrogen/fuel cells }\end{array}$ & [112] \\
\hline S16 & Ballard, C.E. & 2013 & Journal of Chemical Education & Green oxidative homocoupling of 1-methylimidazole & [113] \\
\hline S17 & Ballard, C.E. & 2011 & Journal of Chemical Education & Green reductive homocoupling of bromobenzene & [114] \\
\hline S18 & $\begin{array}{l}\text { Bannin, T.J.; Datta, P.P.; Kiesewetter, E.T.; } \\
\text { Kiesewetter, M.K. }\end{array}$ & 2019 & Journal of Chemical Education & $\begin{array}{l}\text { Synthesizing Stilbene by Olefin Metathesis Reaction Using } \\
\text { Guided Inquiry to Compare and Contrast Wittig and } \\
\text { Metathesis Methodologies }\end{array}$ & [115] \\
\hline S20 & Barcena, H.; Tuachi, A.; Zhang, Y. & 2017 & Journal of Chemical Education & Teaching Green Chemistry with Epoxidized Soybean Oil & [117] \\
\hline S21 & $\begin{array}{l}\text { Behnia, M.S.; Emerson, D.W.; Steinberg, } \\
\text { S.M.; Alwis, R.M.; Duenas, J.A.; Serafino, } \\
\text { J.O. }\end{array}$ & 2011 & Journal of Chemical Education & A simple, safe method for preparation of biodiesel & [118] \\
\hline S22 & $\begin{array}{l}\text { Bendall, S.; Birdsall-Wilson, M.; Jenkins, R.; } \\
\text { Chew, Y.M.J.; Chuck, C.J. }\end{array}$ & 2015 & Journal of Chemical Education & $\begin{array}{l}\text { Showcasing chemical engineering principles through the } \\
\text { production of biodiesel from spent coffee grounds }\end{array}$ & [119] \\
\hline S23 & Bennett, G.D. & 2005 & Journal of Chemical Education & $\begin{array}{l}\text { A green polymerization of aspartic acid for the } \\
\text { undergraduate organic laboratory }\end{array}$ & [120] \\
\hline S24 & Berger, M.; Karod, M.; Goldfarb, J.L. & 2019 & Physical Sciences Reviews & $\begin{array}{l}\text { Invasive species or sustainable water filters? A student-led } \\
\text { laboratory investigation into locally sourced biomass-based } \\
\text { adsorbents for sustainable water treatment }\end{array}$ & [121] \\
\hline
\end{tabular}


Table A1. Cont.

\begin{tabular}{|c|c|c|c|c|c|}
\hline Paper Code & Author(s) & Year & Name of Journal & Title & Ref. \\
\hline S25 & Biswas, R.; Mukherjee, A. & 2017 & Journal of Chemical Education & $\begin{array}{l}\text { Introducing the Concept of Green Synthesis in the } \\
\text { Undergraduate Laboratory: Two-Step Synthesis of } \\
\text { 4-Bromoacetanilide from Aniline }\end{array}$ & [122] \\
\hline S26 & $\begin{array}{l}\text { Blatti, J.L.; Garcia, J.; Cave, D.; Monge, F.; } \\
\text { Cuccinello, A.; Portillo, J.; Juarez, B.; } \\
\text { Chan, E.; Schwebel, F. }\end{array}$ & 2019 & Journal of Chemical Education & $\begin{array}{l}\text { Systems Thinking in Science Education and Outreach } \\
\text { toward a Sustainable Future }\end{array}$ & {$[92]$} \\
\hline S27 & Blatti, J.L. & 2017 & Journal of Chemical Education & $\begin{array}{l}\text { Colorful and Creative Chemistry: Making Simple } \\
\text { Sustainable Paints with Natural Pigments and Binders }\end{array}$ & {$[94]$} \\
\hline S28 & Blatti, J.L.; Burkart, M.D. & 2012 & Journal of Chemical Education & $\begin{array}{l}\text { Releasing stored solar energy within pond scum: Biodiesel } \\
\text { from algal lipids }\end{array}$ & [123] \\
\hline S29 & Bodsgard, B.R.; Lien, N.R.; Waulters, Q.T. & 2016 & Journal of Chemical Education & $\begin{array}{l}\text { Liquid } \mathrm{CO}_{2} \text { Extraction and NMR Characterization of } \\
\text { Anethole from Fennel Seed: A General } \\
\text { Chemistry Laboratory }\end{array}$ & [124] \\
\hline S30 & $\begin{array}{l}\text { Buckley, H.L.; Beck, A.R.; Mulvihill, M.J.; } \\
\text { Douskey, M.C. }\end{array}$ & 2013 & Journal of Chemical Education & $\begin{array}{l}\text { Fitting it all in: Adapting a green chemistry extraction } \\
\text { experiment for inclusion in an undergraduate } \\
\text { analytical laboratory }\end{array}$ & {$[70]$} \\
\hline S32 & Cacciatore, K.L.; Sevian, H. & 2006 & Journal of Chemical Education & $\begin{array}{l}\text { Teaching lab report writing through inquiry: A green } \\
\text { chemistry stoichiometry experiment for general chemistry }\end{array}$ & [126] \\
\hline S33 & $\begin{array}{l}\text { Cardinal, P.; Greer, B.; Luong, H.; } \\
\text { Tyagunova, Y. }\end{array}$ & 2012 & Journal of Chemical Education & $\begin{array}{l}\text { A multistep synthesis incorporating a green bromination of } \\
\text { an aromatic ring }\end{array}$ & {$[71]$} \\
\hline S34 & $\begin{array}{l}\text { Cavalcante Dos Santos, R.; Cabral } \\
\text { Cavalcanti, J.N.; Werneck Do Carmo, E.C.; } \\
\text { De Souza, F.C.; Soares, W.G.; } \\
\text { Gimenes De Souza, C.; } \\
\text { França De Andrade, D.; D'Avila, L.A. }\end{array}$ & 2020 & Journal of Chemical Education & $\begin{array}{l}\text { Approaching Diesel Fuel Quality in Chemistry Lab Classes: } \\
\text { Undergraduate Student's Achievements on Determination } \\
\text { of Biodiesel Content in Diesel Oil Applying } \\
\text { Solvatochromic Effect }\end{array}$ & [127] \\
\hline S35 & $\begin{array}{l}\text { Chan, J.M.W.; Zhang, X.; Brennan, M.K.; } \\
\text { Sardon, H.; Engler, A.C.; Fox, C.H.; Frank, } \\
\text { C.W.; Waymouth, R.M.; Hedrick, J.L. }\end{array}$ & 2015 & Journal of Chemical Education & $\begin{array}{l}\text { Organocatalytic ring-opening polymerization of } \\
\text { trimethylene carbonate to yield a } \\
\text { biodegradable polycarbonate }\end{array}$ & [128] \\
\hline
\end{tabular}


Table A1. Cont.

\begin{tabular}{|c|c|c|c|c|c|}
\hline Paper Code & Author(s) & Year & Name of Journal & Title & Ref. \\
\hline S36 & $\begin{array}{l}\text { Chapman, S.; Herniman, J.M.; Langley, G.J.; } \\
\text { Raja, R.; Logothetis, T.A. }\end{array}$ & 2019 & Journal of Chemical Education & $\begin{array}{l}\text { Redox Aluminophosphates: Applying Fundamental } \\
\text { Undergraduate Theory to Solve Global Challenges in the } \\
\text { Chemical Industry }\end{array}$ & [129] \\
\hline S37 & $\begin{array}{l}\text { Chemat, F.; Perino-Issartier, S.; Petitcolas, E.; } \\
\text { Fernandez, X. }\end{array}$ & 2012 & Analytical and Bioanalytical Chemistry & $\begin{array}{l}\text { "In situ" extraction of essential oils by use of Dean-Stark } \\
\text { glassware and a Vigreux column inside a microwave oven: } \\
\text { A procedure for teaching green analytical chemistry }\end{array}$ & [130] \\
\hline S38 & $\begin{array}{l}\text { Cheney, M.L.; Zaworotko, M.J.; Beaton, S.; } \\
\text { Singer, R.D. }\end{array}$ & 2008 & Journal of Chemical Education & $\begin{array}{l}\text { Cocrystal controlled solid-state synthesis. A green } \\
\text { chemistry experiment for undergraduate organic chemistry }\end{array}$ & [131] \\
\hline S39 & Cheung, L.L.W.; Styler, S.A.; Dicks, A.P. & 2010 & Journal of Chemical Education & $\begin{array}{l}\text { Rapid and convenient synthesis of the 1,4-dihydropyridine } \\
\text { privileged structure }\end{array}$ & [132] \\
\hline S40 & $\begin{array}{l}\text { Christensen, J.E.; Huddle, M.G.; Rogers, J.L.; } \\
\text { Yung, H.; Mohan, R.S. }\end{array}$ & 2008 & Journal of Chemical Education & $\begin{array}{l}\text { The discovery-oriented approach to organic chemistry. } 7 \text {. } \\
\text { Rearrangement of trans-stilbene oxide with bismuth } \\
\text { trifluoromethanesulfonate and other metal triflates: A } \\
\text { microscale green organic chemistry laboratory experiment }\end{array}$ & [133] \\
\hline S41 & Clark, R.A.; Stock, A.E.; Zovinka, E.P. & 2012 & Journal of Chemical Education & $\begin{array}{l}\text { Metalloporphyrins as oxidation catalysts: Moving toward } \\
\text { "greener" chemistry in the inorganic chemistry laboratory }\end{array}$ & [134] \\
\hline S43 & $\begin{array}{l}\text { Colmenares, J.C.; Arévalo-García, E.B.; } \\
\text { Colmenares-Quintero, R.F. }\end{array}$ & 2015 & Journal of Science Education & $\begin{array}{l}\text { A simple method of water purification and energy } \\
\text { extraction from organic wastewater: An application of } \\
\text { green chemistry principles in everyday life }\end{array}$ & {$[20]$} \\
\hline S44 & $\begin{array}{l}\text { Contreras-Cruz, D.A.; Cantú-Reyes, M.; } \\
\text { García-Sánchez, J.M.; Peña-Ortíz, D.; } \\
\text { Sánchez-Carmona, M.A.; Miranda, L.D. }\end{array}$ & 2019 & Journal of Chemical Education & $\begin{array}{l}\text { Shedding blue light on the undergraduate laboratory: an } \\
\text { easy-to-assemble LED Photoreactor for Aromatization of a } \\
\text { 1,4-Dihydropyridine }\end{array}$ & [136] \\
\hline S45 & Cooper, P.D.; Walser, J. & 2019 & Journal of Chemical Education & $\begin{array}{l}\text { Total Chemical Footprint of an Experiment: A Systems } \\
\text { Thinking Approach to Teaching } \\
\text { Rovibrational Spectroscopy }\end{array}$ & [137] \\
\hline
\end{tabular}


Table A1. Cont.

\begin{tabular}{|c|c|c|c|c|c|}
\hline Paper Code & Author(s) & Year & Name of Journal & Title & Ref. \\
\hline S46 & $\begin{array}{l}\text { Cosio, M.N.; Cardenal, A.D.; Maity, A.; } \\
\text { Hyun, S.-M.; Akwaowo, V.E.; } \\
\text { Hoffman, C.W.; Powers, T.M.; Powers, D.C. }\end{array}$ & 2020 & Journal of Chemical Education & $\begin{array}{l}\text { Exploring Green Chemistry with Aerobic Hypervalent } \\
\text { Iodine Catalysis }\end{array}$ & [138] \\
\hline S47 & $\begin{array}{l}\text { Costa, N.E.; Pelotte, A.L.; Simard, J.M.; } \\
\text { Syvinski, C.A.; Deveau, A.M. }\end{array}$ & 2012 & Journal of Chemical Education & $\begin{array}{l}\text { Discovering green, aqueous Suzuki coupling reactions: } \\
\text { Synthesis of ethyl (4-phenylphenyl)acetate, a biaryl with } \\
\text { anti-arthritic potential }\end{array}$ & [139] \\
\hline S48 & Desmond, S.; Ray, C.; Andino Martínez, J.G. & 2019 & Physical Sciences Reviews & Educational benefits of green chemistry & [140] \\
\hline S50 & Dias, A.M.; Ferreira, M.L.S. & 2015 & Journal of Chemical Education & $\begin{array}{l}\text { "Supermarket column chromatography of leaf pigments" } \\
\text { revisited: Simple and ecofriendly separation of plant } \\
\text { carotenoids, chlorophylls, and flavonoids from green and } \\
\text { red leaves }\end{array}$ & [93] \\
\hline S51 & $\begin{array}{l}\text { Dicks, A.P.; D’Eon, J.C.; Morra, B.; } \\
\text { Kutas Chisu C.; Quinlan, K.B.; Cannon, A.S. }\end{array}$ & 2019 & Journal of Chemical Education & $\begin{array}{l}\text { A Systems Thinking Department: Fostering a Culture of } \\
\text { Green Chemistry Practice among Students }\end{array}$ & [142] \\
\hline S53 & Dicks, A.P. & 2009 & Green Chemistry Letters and Reviews & $\begin{array}{l}\text { Solvent-free reactivity in the undergraduate } \\
\text { organic laboratory }\end{array}$ & {$[56]$} \\
\hline S54 & Dicks, A.P. & 2009 & Green Chemistry Letters and Reviews & $\begin{array}{l}\text { A review of aqueous organic reactions for the } \\
\text { undergraduate teaching laboratory }\end{array}$ & {$[57]$} \\
\hline S55 & $\begin{array}{l}\text { Dintzner, M.R.; Kinzie, C.R.; Pulkrabek, K.; } \\
\text { Arena, A.F. }\end{array}$ & 2012 & Journal of Chemical Education & $\begin{array}{l}\text { The cyclohexanol cycle and synthesis of nylon 6,6: Green } \\
\text { chemistry in the undergraduate organic laboratory }\end{array}$ & [143] \\
\hline S56 & $\begin{array}{l}\text { Dintzner, M.R.; Maresh, J.J.; Kinzie, C.R.; } \\
\text { Arena, A.F.; Speltz, T. }\end{array}$ & 2012 & Journal of Chemical Education & $\begin{array}{l}\text { A research-based undergraduate organic laboratory project: } \\
\text { Investigation of a one-pot, multicomponent, } \\
\text { environmentally friendly prins-friedel-crafts-type reaction }\end{array}$ & [144] \\
\hline S57 & Divya, D.; Raj, K.G. & 2019 & Journal of Chemical Education & $\begin{array}{l}\text { From Scrap to Functional Materials: Exploring Green and } \\
\text { Sustainable Chemistry Approach in the } \\
\text { Undergraduate Laboratory }\end{array}$ & [145] \\
\hline
\end{tabular}


Table A1. Cont.

\begin{tabular}{|c|c|c|c|c|c|}
\hline Paper Code & Author(s) & Year & Name of Journal & Title & Ref. \\
\hline S58 & $\begin{array}{l}\text { Dorney, K.M.; Baker, J.D.; Edwards, M.L.; } \\
\text { Kanel, S.R.; O'Malley, M.; Sizemore, I.E.P. }\end{array}$ & 2014 & Journal of Chemical Education & $\begin{array}{l}\text { Tangential flow filtration of colloidal silver nanoparticles: A } \\
\text { "green" laboratory experiment for chemistry and } \\
\text { engineering students }\end{array}$ & [146] \\
\hline S59 & $\begin{array}{l}\text { dos Santos, R.V.; Viana, G.M.; } \\
\text { Moreira, A.F.S.; Nóbrega, V.S.; } \\
\text { da Silva, V.A.S.; Malta, L.F.B.; Aguiar; L.C.S.; } \\
\text { Senra, J.D. }\end{array}$ & 2019 & Quimica Nova & $\begin{array}{l}\text { Revisiting the nucleophilicity concept in a comprehensive } \\
\text { biomass valorization experiment: From papaya seeds to } \\
\text { thiourea motifs }\end{array}$ & [147] \\
\hline S61 & $\begin{array}{l}\text { Edgar, L.J.G.; Koroluk, K.J.; Golmakani, M.; } \\
\text { Dicks, A.P. }\end{array}$ & 2014 & Journal of Chemical Education & $\begin{array}{l}\text { Green chemistry decision-making in an upper-level } \\
\text { undergraduate organic laboratory }\end{array}$ & [148] \\
\hline S62 & Eissen, $\mathrm{M}$. & 2012 & Chemistry Education Research and Practice & $\begin{array}{l}\text { Sustainable production of chemicals-an } \\
\text { educational perspective }\end{array}$ & [149] \\
\hline S63 & Félix, S.; Araújo, J.; Pires, A.M.; Sousa, A.C. & 2017 & Waste Management & Soap production: A green prospective & [150] \\
\hline S65 & Förster, C.; Heinze, K. & 2020 & Journal of Chemical Education & $\begin{array}{l}\text { Preparation and Thermochromic Switching between } \\
\text { Phosphorescence and Thermally Activated Delayed } \\
\text { Fluorescence of Mononuclear Copper(I) Complexes }\end{array}$ & [151] \\
\hline S66 & $\begin{array}{l}\text { Gabriela, M.; Ribeiro, T.C.; } \\
\text { MacHado, A.A.S.C. }\end{array}$ & 2011 & Journal of Chemical Education & $\begin{array}{l}\text { Metal-acetylacetonate synthesis experiments: Which } \\
\text { is greener? }\end{array}$ & [83] \\
\hline S67 & Garner, N.; Siol, A.; Eilks, I. & 2016 & Journal of Science Education & $\begin{array}{l}\text { The synthesis of vanillin-learning about aspects of } \\
\text { sustainable chemistry by comparing different syntheses }\end{array}$ & [73] \\
\hline S68 & Geiger, H.C.; Donohoe, J.S. & 2012 & Journal of Chemical Education & $\begin{array}{l}\text { Green oxidation of menthol enantiomers and analysis by } \\
\text { circular dichroism spectroscopy: An advanced organic } \\
\text { chemistry laboratory }\end{array}$ & [152] \\
\hline S69 & Ginzburg, A.L.; Baca, N.A.; Hampton, P.D. & 2014 & Journal of Chemical Education & $\begin{array}{l}\text { The Isomerization of (-)-Menthone to (+)-Isomenthone } \\
\text { Catalyzed by an Ion-Exchange Resin }\end{array}$ & {$[74]$} \\
\hline
\end{tabular}


Table A1. Cont.

\begin{tabular}{|c|c|c|c|c|c|}
\hline Paper Code & Author(s) & Year & Name of Journal & Title & Ref. \\
\hline S70 & $\begin{array}{l}\text { Go, E.B.; Srisuknimit, V.; Cheng, S.L.; } \\
\text { Vosburg, D.A. }\end{array}$ & 2016 & Journal of Chemical Education & $\begin{array}{l}\text { Self-Assembly, Guest Capture, and NMR Spectroscopy of a } \\
\text { Metal-Organic Cage in Water }\end{array}$ & [153] \\
\hline S71 & Gómez-Biagi, R.F.; Dicks, A.P. & 2015 & Journal of Chemical Education & $\begin{array}{l}\text { Assessing Process Mass Intensity and Waste via an } \\
\text { aza-Baylis-Hillman Reaction }\end{array}$ & {$[81]$} \\
\hline S72 & Goodwin, T.E. & 2004 & Journal of Chemical Education & $\begin{array}{l}\text { An asymptotic approach to the development of a green } \\
\text { organic chemistry laboratory }\end{array}$ & [154] \\
\hline S73 & $\begin{array}{l}\text { Graham, K.J.; Jones, T.N.; Schaller, C.P.; } \\
\text { McIntee, E.J. }\end{array}$ & 2014 & Journal of Chemical Education & $\begin{array}{l}\text { Implementing a student-designed green chemistry } \\
\text { laboratory project in organic chemistry }\end{array}$ & {$[75]$} \\
\hline S74 & Grieger, K.; Leontyev, A. & 2020 & Journal of Chemical Education & $\begin{array}{l}\text { Promoting student awareness of green chemistry principles } \\
\text { via student-generated presentation videos }\end{array}$ & {$[90]$} \\
\hline S75 & Günter, T.; Akkuzu, N.; Alpat, Ş. & 2017 & Research in Science and Technological Education & $\begin{array}{l}\text { Understanding 'green chemistry' and 'sustainability': an } \\
\text { example of problem-based learning (PBL) }\end{array}$ & [155] \\
\hline S76 & Guron, M.; Paul, J.J.; Roeder, M.H. & 2016 & Journal of Chemical Education & $\begin{array}{l}\text { Incorporating Sustainability and Life Cycle Assessment } \\
\text { into First-Year Inorganic Chemistry Major Laboratories }\end{array}$ & {$[88]$} \\
\hline S77 & $\begin{array}{l}\text { Haack, J.A.; Hutchison, J.E.; Kirchhoff, M.M.; } \\
\text { Levy, I.J. }\end{array}$ & 2005 & Journal of Chemical Education & $\begin{array}{l}\text { Going green: Lecture assignments and lab experiences for } \\
\text { the college curriculum }\end{array}$ & {$[11]$} \\
\hline S78 & $\begin{array}{l}\text { Hamilton, A.E.; Buxton, A.M.; Peeples, C.J.; } \\
\text { Chalker, J.M. }\end{array}$ & 2013 & Journal of Chemical Education & $\begin{array}{l}\text { An operationally simple aqueous Suzuki-Miyaura } \\
\text { cross-coupling reaction for an undergraduate organic } \\
\text { chemistry laboratory }\end{array}$ & [156] \\
\hline S79 & Hie, L.; Chang, J.J.; Garg, N.K. & 2015 & Journal of Chemical Education & $\begin{array}{l}\text { Nickel-catalyzed Suzuki-Miyaura cross-coupling in a green } \\
\text { alcohol solvent for an undergraduate organic } \\
\text { chemistry laboratory }\end{array}$ & [157] \\
\hline S80 & $\begin{array}{l}\text { Hill, N.J.; Bowman, M.D.; Esselman, B.J.; } \\
\text { Byron, S.D.; Kreitinger, J.; Leadbeater, N.E. }\end{array}$ & 2014 & Journal of Chemical Education & $\begin{array}{l}\text { Ligand-free suzuki-miyaura coupling reactions using an } \\
\text { inexpensive aqueous palladium source: A synthetic and } \\
\text { computational exercise for the undergraduate organic } \\
\text { chemistry laboratory }\end{array}$ & [158] \\
\hline S81 & Hill, N.J.; Hoover, J.M.; Stahl, S.S. & 2013 & Journal of Chemical Education & $\begin{array}{l}\text { Aerobic alcohol oxidation using a copper(I)/TEMPO } \\
\text { catalyst system: A green, catalytic oxidation reaction for the } \\
\text { undergraduate organic chemistry laboratory }\end{array}$ & [159] \\
\hline
\end{tabular}


Table A1. Cont.

\begin{tabular}{|c|c|c|c|c|c|}
\hline Paper Code & Author(s) & Year & Name of Journal & Title & Ref. \\
\hline S82 & $\begin{array}{l}\text { Hoang, G.T.; Kubo, T.; Young, V.G., Jr.; } \\
\text { Kautzky, J.A.; Wissinger, J.E. }\end{array}$ & 2015 & Journal of Chemical Education & $\begin{array}{l}\text { Illustrating the Utility of X-ray Crystallography for } \\
\text { Structure Elucidation through a Tandem Aldol } \\
\text { Condensation/Diels-Alder Reaction Sequence }\end{array}$ & [160] \\
\hline S83 & Hoffman, K.C.; Dicks, A.P. & 2020 & Sustainable Chemistry and Pharmacy & $\begin{array}{l}\text { Shifting the paradigm of chemistry education by Greening } \\
\text { the high school laboratory }\end{array}$ & {$[23]$} \\
\hline S84 & Hopson, R.; Lee, P.Y.B.; Hess, K.M. & 2018 & Journal of Chemical Education & $\begin{array}{l}\text { 1-Dimensional Selective Nuclear Overhauser Effect NMR } \\
\text { Spectroscopy to Characterize Products from a Two-Step } \\
\text { Green Chemistry Synthesis }\end{array}$ & [161] \\
\hline S85 & Horta, J.E. & 2011 & Journal of Chemical Education & $\begin{array}{l}\text { Simple microwave-assisted Claisen and Dieckmann } \\
\text { condensation experiments for the undergraduate organic } \\
\text { chemistry laboratory }\end{array}$ & [162] \\
\hline S86 & $\begin{array}{l}\text { Hudson, R.; Ackerman, H.M.; Gallo, L.K.; } \\
\text { Gwinner, A.S.; Krauss, A.; Sears, J.D.; } \\
\text { Bishop, A.; Esdale, K.N.; Katz, J.L. }\end{array}$ & 2017 & Journal of Chemical Education & $\begin{array}{l}\mathrm{CO}_{2} \text { Dry Cleaning: A Benign Solvent Demonstration } \\
\text { Accessible to K-8 Audiences }\end{array}$ & {$[21]$} \\
\hline S87 & Hurst, G.A. & 2020 & $\begin{array}{l}\text { Current Opinion in Green and Sustainable } \\
\text { Chemistry }\end{array}$ & $\begin{array}{l}\text { Systems thinking approaches for international green } \\
\text { chemistry education }\end{array}$ & [87] \\
\hline S89 & $\begin{array}{l}\text { Hwang, H.L.; Jadhav, S.R.; Silverman, J.R.; } \\
\text { John, G. }\end{array}$ & 2014 & Journal of Chemical Education & $\begin{array}{l}\text { Sweet and Sustainable: Teaching the Biorefinery Concept } \\
\text { through Biobased Gelator Synthesis }\end{array}$ & [164] \\
\hline S90 & Ison, E.A.; Ison, A. & 2012 & Journal of Chemical Education & $\begin{array}{l}\text { Synthesis of well-defined copper N-heterocyclic carbene } \\
\text { complexes and their use as catalysts for a "click reaction": } \\
\text { A multistep experiment that emphasizes the role of } \\
\text { catalysis in green chemistry }\end{array}$ & [165] \\
\hline S91 & $\begin{array}{l}\text { Johnston, A.; Scaggs, J.; Mallory, C.; } \\
\text { Haskett, A.; Warner, D.; Brown, E.; } \\
\text { Hammond, K.; McCormick, M.M.; } \\
\text { McDougal, O.M. }\end{array}$ & 2013 & Journal of Chemical Education & $\begin{array}{l}\text { A green approach to separate spinach pigments by } \\
\text { column chromatography }\end{array}$ & [166] \\
\hline S92 & Jones-Wilson, T.M.; Burtch, E.A. & 2005 & Journal of Chemical Education & $\begin{array}{l}\text { A green starting material for electrophilic aromatic } \\
\text { substitution for the undergraduate organic laboratory }\end{array}$ & [167] \\
\hline
\end{tabular}


Table A1. Cont.

\begin{tabular}{|c|c|c|c|c|c|}
\hline Paper Code & Author(s) & Year & Name of Journal & Title & Ref. \\
\hline S93 & $\begin{array}{l}\text { Josephson, P.; Nykvist, V.; Qasim, W.; } \\
\text { Blomkvist, B.; DInér, P. }\end{array}$ & 2019 & Journal of Chemical Education & $\begin{array}{l}\text { Student-Driven Development of Greener Chemistry in } \\
\text { Undergraduate Teaching: Synthesis of Lidocaine Revisited }\end{array}$ & {$[76]$} \\
\hline S94 & Karpudewan, M.; Kulandaisamy, Y. & 2018 & $\begin{array}{l}\text { Current Opinion in Green and Sustainable } \\
\text { Chemistry }\end{array}$ & $\begin{array}{l}\text { Malaysian teachers' insights into implementing green } \\
\text { chemistry experiments in secondary schools }\end{array}$ & [99] \\
\hline S95 & Karpudewan, M.; Mathanasegaran, K. & 2018 & $\begin{array}{l}\text { Asia-Pacific Forum on Science Learning and } \\
\text { Teaching }\end{array}$ & $\begin{array}{l}\text { Exploring the use of context-based green chemistry } \\
\text { experiments in understanding the effects of concentration } \\
\text { and catalyst on the rate of reaction }\end{array}$ & [168] \\
\hline S97 & Karpudewan, M.; Ismail, Z.; Roth, W.-M. & 2012 & Journal of Science Teacher Education & $\begin{array}{l}\text { Fostering Pre-service Teachers' Self-Determined } \\
\text { Environmental Motivation Through Green } \\
\text { Chemistry Experiments }\end{array}$ & {$[95]$} \\
\hline S98 & Karpudewan, M.; Ismail, Z.; Roth, W.-M. & 2012 & Chemistry Education Research and Practice & $\begin{array}{l}\text { Ensuring sustainability of tomorrow through green } \\
\text { chemistry integrated with sustainable development } \\
\text { concepts (SDCs) }\end{array}$ & {$[96]$} \\
\hline S100 & $\begin{array}{l}\text { Karpudewan, M.; Ismail, Z.H.; } \\
\text { Mohamed, N. }\end{array}$ & 2009 & $\begin{array}{l}\text { International Journal of Sustainability in } \\
\text { Higher Education }\end{array}$ & $\begin{array}{l}\text { The integration of green chemistry experiments with } \\
\text { sustainable development concepts in pre-service teachers' } \\
\text { curriculum: Experiences from Malaysia }\end{array}$ & [39] \\
\hline S101 & $\begin{array}{l}\text { Keen, C.; Couture, S.; Abd El Meseh, N.; } \\
\text { Sevian, H. }\end{array}$ & 2020 & Journal of Chemical Education & $\begin{array}{l}\text { Connecting Theory to Life: Learning Greener } \\
\text { Electrochemistry by Taking Apart a Common Battery }\end{array}$ & [170] \\
\hline S102 & $\begin{array}{l}\text { Kelly, M.J.B.; Fallot, L.B.; Gustafson, J.L.; } \\
\text { Bergdahl, B.M. }\end{array}$ & 2016 & Journal of Chemical Education & $\begin{array}{l}\text { Water Mediated Wittig Reactions of Aldehydes in the } \\
\text { Teaching Laboratory: Using Sodium Bicarbonate for the in } \\
\text { Situ Formation of Stabilized Ylides }\end{array}$ & [171] \\
\hline S103 & Khuong, K.S. & 2017 & Journal of Chemical Education & $\begin{array}{l}\text { Greener Oxidation of Benzhydrol: Evaluating Three } \\
\text { Oxidation Procedures in the Organic Laboratory }\end{array}$ & [172] \\
\hline S104 & $\begin{array}{l}\text { Klingshirn, M.A.; Wyatt, A.F.; Hanson, R.M.; } \\
\text { Spessard, G.O. }\end{array}$ & 2008 & Journal of Chemical Education & $\begin{array}{l}\text { Determination of the formula of a hydrate: } \\
\text { A greener alternative }\end{array}$ & [173] \\
\hline
\end{tabular}


Table A1. Cont.

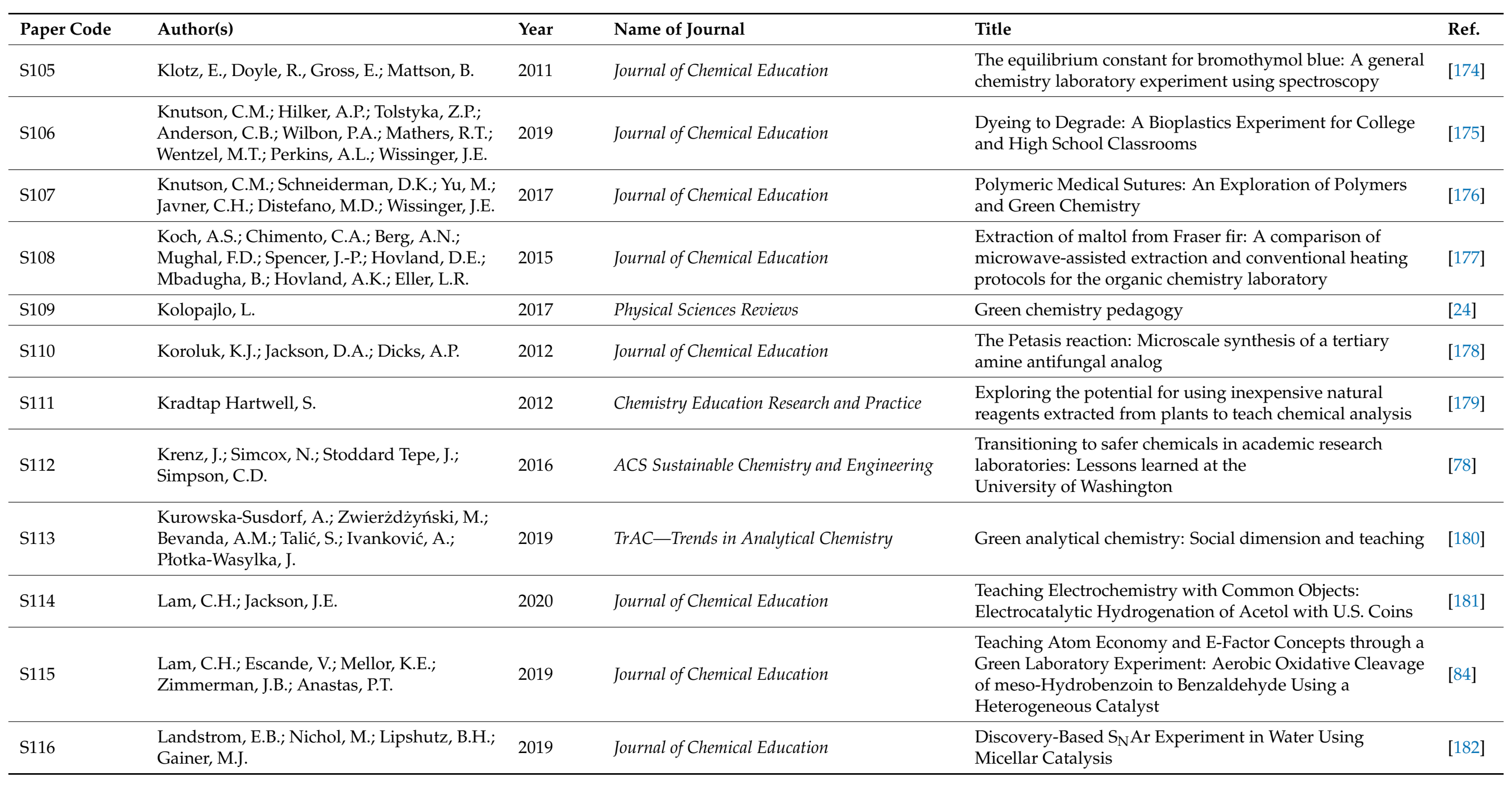


Table A1. Cont.

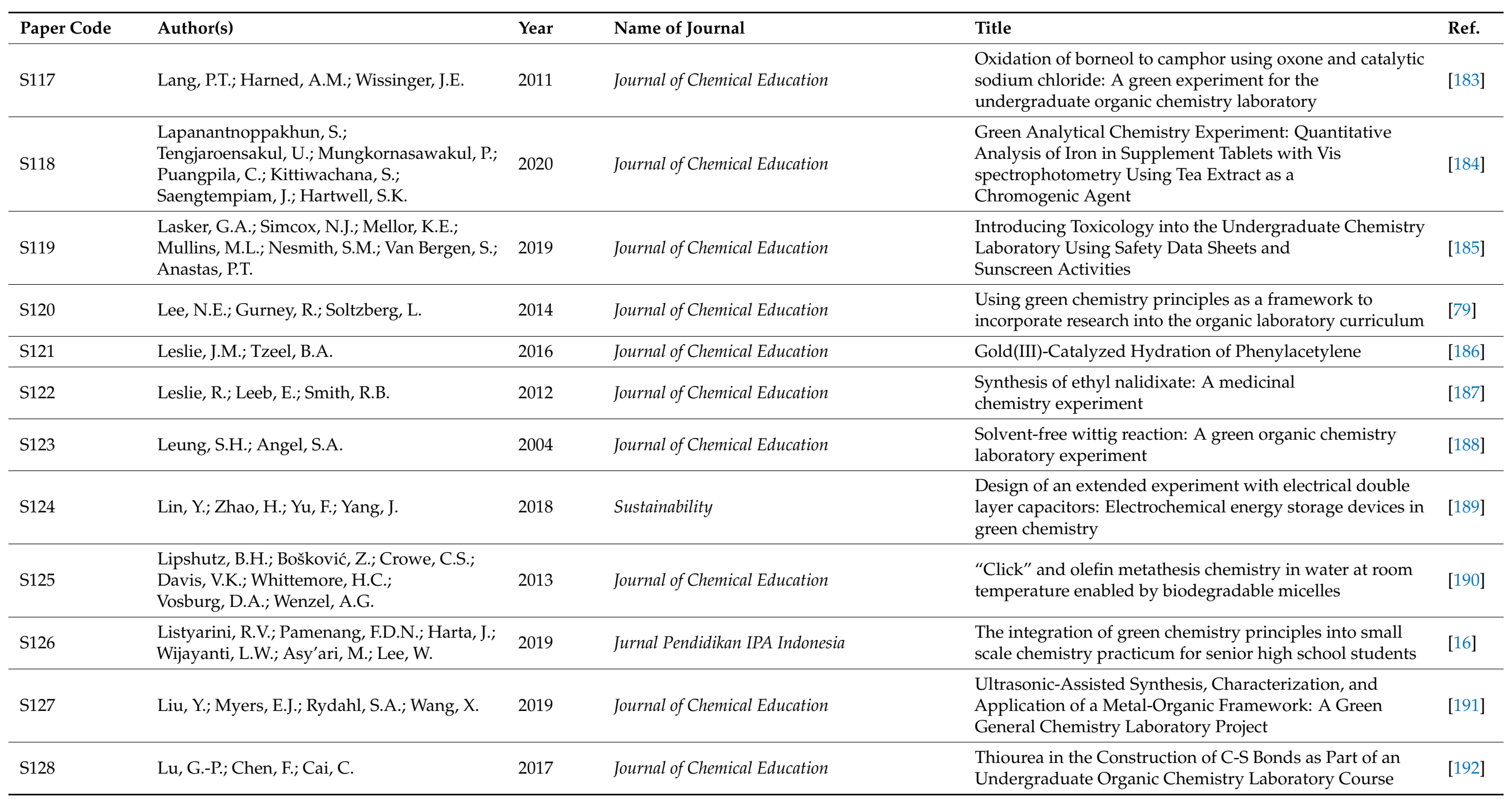


Table A1. Cont.

\begin{tabular}{|c|c|c|c|c|c|}
\hline Paper Code & Author(s) & Year & Name of Journal & Title & Ref. \\
\hline S129 & $\begin{array}{l}\text { Mackenzie, L.S.; Tyrrell, H.; Thomas, R.; } \\
\text { Matharu, A.S.; Clark, J.H.; Hurst, G.A. }\end{array}$ & 2019 & Journal of Chemical Education & $\begin{array}{l}\text { Valorization of Waste Orange Peel to Produce } \\
\text { Shear-Thinning Gels }\end{array}$ & [193] \\
\hline S130 & Manchanayakage, R. & 2013 & Journal of Chemical Education & $\begin{array}{l}\text { Designing and incorporating green chemistry courses at a } \\
\text { liberal arts college to increase students' awareness and } \\
\text { interdisciplinary collaborative work }\end{array}$ & [194] \\
\hline S131 & $\begin{array}{l}\text { Marcos, C.F.; Neo, A.G.; Díaz, J.; } \\
\text { Martínez-Caballero, S. }\end{array}$ & 2020 & Journal of Chemical Education & $\begin{array}{l}\text { A Safe and Green Benzylic Radical } \\
\text { Bromination Experiment }\end{array}$ & [195] \\
\hline S133 & McAllister, G.D.; Parsons, A.F. & 2019 & Journal of Chemical Education & $\begin{array}{l}\text { Going Green in Process Chemistry: Optimizing an } \\
\text { Asymmetric Oxidation Reaction to Synthesize the Antiulcer } \\
\text { Drug Esomeprazole }\end{array}$ & [197] \\
\hline S134 & $\begin{array}{l}\text { McKee, J.R.; Zanger, M.; Chiariello, C.; } \\
\text { McKee, J.A.; Dorfner, W.; Fasella, E.; Koo, Y. }\end{array}$ & 2019 & Journal of Chemical Education & $\begin{array}{l}\text { Semimicro/Microscale Adaptation of the Cobalt } \\
\text { Chloride/Sodium Borohydride Reduction of Methyl Oleate }\end{array}$ & [198] \\
\hline S135 & $\begin{array}{l}\text { McKenzie, L.C.; Huffman, L.M.; Parent, K.E.; } \\
\text { Hutchison, J.E.; Thompson, J.E. }\end{array}$ & 2004 & Journal of Chemical Education & $\begin{array}{l}\text { Patterning Self-Assembled Monolayers on Gold: Green } \\
\text { Materials Chemistry in the Teaching Laboratory }\end{array}$ & [199] \\
\hline S136 & Mio, M.J. & 2017 & Physical Sciences Reviews & $\begin{array}{l}\text { How the principles of green chemistry changed the way } \\
\text { organic chemistry labs are taught at the university of } \\
\text { detroit mercy }\end{array}$ & [200] \\
\hline S137 & Mohan, R.S.; Mejia, M.P. & 2020 & Journal of Chemical Education & $\begin{array}{l}\text { Environmentally Friendly Organic Chemistry Laboratory } \\
\text { Experiments for the Undergraduate Curriculum: A } \\
\text { Literature Survey and Assessment }\end{array}$ & [201] \\
\hline S138 & Mooney, D. & 2004 & Chemical Health and Safety & $\begin{array}{l}\text { Effectively minimizing hazardous waste in academia: The } \\
\text { Green Chemistry approach }\end{array}$ & [202] \\
\hline S139 & $\begin{array}{l}\text { Mooney, M.; Vreugdenhil, A.J.; } \\
\text { Shetranjiwalla, S. }\end{array}$ & 2020 & Journal of Chemical Education & $\begin{array}{l}\text { A Toolkit of Green Chemistry and Life-Cycle Analysis for } \\
\text { Comparative Assessment in Undergraduate Organic } \\
\text { Chemistry Experiments: Synthesis of (E)-Stilbene }\end{array}$ & [203] \\
\hline S140 & $\begin{array}{l}\text { Morris, R.K.; Hilker, A.P.; Mattice, T.M.; } \\
\text { Donovan, S.M.; Wentzel, M.T.; } \\
\text { Willoughby, P.H. }\end{array}$ & 2019 & Journal of Chemical Education & $\begin{array}{l}\text { Simple and Versatile Protocol for Preparing Self-Healing } \\
\text { Poly(vinyl alcohol) Hydrogels }\end{array}$ & [204] \\
\hline
\end{tabular}


Table A1. Cont.

\begin{tabular}{|c|c|c|c|c|c|}
\hline Paper Code & Author(s) & Year & Name of Journal & Title & Ref. \\
\hline S141 & $\begin{array}{l}\text { Morsch, L.A.; Deak, L.; Tiburzi, D.; } \\
\text { Schuster, H.; Meyer, B. }\end{array}$ & 2014 & Journal of Chemical Education & $\begin{array}{l}\text { Green aqueous wittig reaction: Teaching green chemistry in } \\
\text { organic teaching laboratories }\end{array}$ & [205] \\
\hline S142 & Mullins, J.J.; Prusinowski, A.F. & 2019 & Journal of Chemical Education & $\begin{array}{l}\text { Microwave-Promoted Synthesis of a Carbocyclic } \\
\text { Curcuminoid: An Organic Chemistry } \\
\text { Laboratory Experiment }\end{array}$ & [206] \\
\hline S143 & $\begin{array}{l}\text { Murphy, K.C.; Dilip, M.; Quattrucci, J.G.; } \\
\text { Mitroka, S.M.; Andreatta, J.R. }\end{array}$ & 2019 & Journal of Chemical Education & $\begin{array}{l}\text { Sustainable Consumer Choices: An Outreach Program } \\
\text { Exploring the Environmental Impact of Our Consumer } \\
\text { Choices Using a Systems Thinking Model and } \\
\text { Laboratory Activities }\end{array}$ & [207] \\
\hline S144 & Narayan, S. & 2020 & Physical Sciences Reviews & $\begin{array}{l}\text { Sustainability and some green initiatives in } \\
\text { undergraduate education }\end{array}$ & [58] \\
\hline S145 & $\begin{array}{l}\text { Nigam, M.; Rush, B.; Patel, J.; Castillo, R.; } \\
\text { Dhar, P. }\end{array}$ & 2016 & Journal of Chemical Education & $\begin{array}{l}\text { Aza-Michael Reaction for an Undergraduate Organic } \\
\text { Chemistry Laboratory }\end{array}$ & [208] \\
\hline S146 & $\begin{array}{l}\text { Obhi, N.K.; Mallov, I.; } \\
\text { Borduas-Dedekind, N.; Rousseaux, S.A.L.; } \\
\text { Dicks, A.P. }\end{array}$ & 2019 & Journal of Chemical Education & $\begin{array}{l}\text { Comparing Industrial Amination Reactions in a Combined } \\
\text { Class and Laboratory Green Chemistry Assignment }\end{array}$ & [209] \\
\hline S147 & $\begin{array}{l}\text { Orwat, K.; Bernard, P.; Wróblewski, S.; } \\
\text { Mendez, J.D. }\end{array}$ & 2018 & $\begin{array}{l}\text { Macedonian Journal of Chemistry and Chemical } \\
\text { Engineering }\end{array}$ & $\begin{array}{l}\text { Traditional vs. UV-cured coatings-An inquiry-based } \\
\text { experiment for introducing green chemistry }\end{array}$ & [77] \\
\hline S148 & $\begin{array}{l}\text { Paluri, S.L.A.; Edwards, M.L.; Lam, N.H.; } \\
\text { Williams, E.M.; Meyerhoefer, A.; } \\
\text { Sizemore, I.E.P. }\end{array}$ & 2015 & Journal of Chemical Education & $\begin{array}{l}\text { Introducing green and nongreen aspects of noble metal } \\
\text { nanoparticle synthesis: An inquiry-based laboratory } \\
\text { experiment for chemistry and engineering students }\end{array}$ & [210] \\
\hline S149 & $\begin{array}{l}\text { Panda, D.; Patra, S.; Awasthi, M.K.; } \\
\text { Singh, S.K. }\end{array}$ & 2020 & ACS applied materials $\mathcal{E}$ interfaces & $\begin{array}{l}\text { Lab Cooked MOF for } \mathrm{CO}_{2} \text { Capture: A Sustainable Solution } \\
\text { to Waste Management }\end{array}$ & [211] \\
\hline S150 & $\begin{array}{l}\text { Pandarus, V.; Ciriminna, R.; Béland, F.; } \\
\text { Pagliaro, M. }\end{array}$ & 2020 & Applied Materials Today & $\begin{array}{l}\text { Making fine chemicals, nanomaterials and pharmaceutical } \\
\text { ingredients over SiliaCat catalysts }\end{array}$ & [212] \\
\hline S151 & Panzarasa, G. & 2018 & ACS Omega & $\begin{array}{l}\text { Just Add Luminol to Turn the Spotlight on } \\
\text { Radziszewski Amidation }\end{array}$ & [213] \\
\hline S152 & Panzarasa, G.; Sparnacci, K. & 2012 & Journal of Chemical Education & $\begin{array}{l}\text { Glowing teacup demonstration: Trautz-schorigin reaction } \\
\text { of natural polyphenols }\end{array}$ & [214] \\
\hline
\end{tabular}


Table A1. Cont.

\begin{tabular}{|c|c|c|c|c|c|}
\hline Paper Code & Author(s) & Year & Name of Journal & Title & Ref. \\
\hline S153 & $\begin{array}{l}\text { Patterson, A.L.; May, M.D.; Visser, B.J.; } \\
\text { Kislukhin, A.A.; Vosburg, D.A. }\end{array}$ & 2013 & Journal of Chemical Education & $\begin{array}{l}\text { Solvent-free synthesis and fluorescence of a thiol-reactive } \\
\text { sensor for undergraduate organic laboratories }\end{array}$ & [215] \\
\hline S154 & $\begin{array}{l}\text { Peng, H.-C.; Bryan, J.; Henson, W.; } \\
\text { Zhdankin, V.V.; Gandhi, K.; David, S. }\end{array}$ & 2019 & Journal of Chemical Education & $\begin{array}{l}\text { New, Milder Hypervalent Iodine Oxidizing Agent: Using } \\
\mu \text {-Oxodi(phenyliodanyl) Diacetate, a } \\
\text { (Diacetoxyiodo)benzene Derivative, in the Synthesis } \\
\text { of Quinones }\end{array}$ & [216] \\
\hline S155 & $\begin{array}{l}\text { Pereira, T.M.;Franco, D.F.P.; Vitório, F.; } \\
\text { Amaral, R.C.; Ponzoni, A.C.; } \\
\text { Kümmerle, A.E. }\end{array}$ & 2018 & Quimica Nova & $\begin{array}{l}\text { Microwave-assisted synthesis and pka determination of } \\
\text { umbelliferone: An experiment for the undergraduate } \\
\text { organic chemistry laboratory }\end{array}$ & [217] \\
\hline S156 & Pfab, E.; Filiciotto, L.; Luque, R. & 2019 & Journal of Chemical Education & $\begin{array}{l}\text { The Dark Side of Biomass Valorization: A Laboratory } \\
\text { Experiment to Understand Humin Formation, Catalysis, } \\
\text { and Green Chemistry }\end{array}$ & [218] \\
\hline S157 & $\begin{array}{l}\text { Płotka-Wasylka, J.; Kurowska-Susdorf, A.; } \\
\text { Sajid, M.; de la Guardia, M.; Namieśnik, J.; } \\
\text { Tobiszewski, M. }\end{array}$ & 2018 & ChemSusChem & $\begin{array}{l}\text { Green Chemistry in Higher Education: State of the Art, } \\
\text { Challenges, and Future Trends }\end{array}$ & {$[52]$} \\
\hline S158 & Pohl, N.L.B.; Streff, J.M.; Brokman, S. & 2012 & Journal of Chemical Education & $\begin{array}{l}\text { Evaluating sustainability: Soap versus biodiesel production } \\
\text { from plant oils }\end{array}$ & [219] \\
\hline S159 & Priest, M.A.; Padgett, L.W.; Padgett, C.W. & 2011 & Journal of Chemical Education & $\begin{array}{l}\text { Demonstrating the temperature dependence of density via } \\
\text { construction of a Galilean thermometer }\end{array}$ & [220] \\
\hline S160 & $\begin{array}{l}\text { Purcell, S.C.; Pande, P.; Lin, Y.; Rivera, E.J.; } \\
\text { Latisha, P.U.; Smallwood, L.M.; } \\
\text { Kerstiens, G.A.; Armstrong, L.B.; } \\
\text { Robak, M.T.; Baranger, A.M.; Douskey, M.C. }\end{array}$ & 2016 & Journal of Chemical Education & $\begin{array}{l}\text { Extraction and Antibacterial Properties of Thyme Leaf } \\
\text { Extracts: Authentic Practice of Green Chemistry }\end{array}$ & [221] \\
\hline S161 & $\begin{array}{l}\text { Raghuwanshi, V.S.; Wendt, R.; O’Neill, M.; } \\
\text { Ochmann, M.; Som, T.; Fenger, R.; } \\
\text { Mohrmann, M.; Hoell, A.; Rademann, K. }\end{array}$ & 2017 & Journal of Chemical Education & $\begin{array}{l}\text { Bringing Catalysis with Gold Nanoparticles in Green } \\
\text { Solvents to Graduate Level Students }\end{array}$ & [222] \\
\hline S162 & $\begin{array}{l}\text { Rajapaksha, S.M.; Samarasekara, D.; } \\
\text { Brown, J.C.; Howard, L.; Gerken, K.; } \\
\text { Archer, T.; Lathan, P.; Mlsna, T.; Mlsna, D. }\end{array}$ & 2018 & Journal of Chemical Education & $\begin{array}{l}\text { Determination of Xylitol in Sugar-Free Gum by GC-MS } \\
\text { with Direct Aqueous Injection: A Laboratory Experiment } \\
\text { for Chemistry Students }\end{array}$ & [223] \\
\hline S163 & Rajchakit, U.; Limpanuparb, T. & 2016 & Journal of Chemical Education & $\begin{array}{l}\text { Greening the Traffic Light: Air Oxidation of Vitamin C } \\
\text { Catalyzed by Indicators }\end{array}$ & [224] \\
\hline
\end{tabular}


Table A1. Cont.

\begin{tabular}{|c|c|c|c|c|c|}
\hline Paper Code & Author(s) & Year & Name of Journal & Title & Ref. \\
\hline S164 & Rattanakit, P.; Maungchang, R. & 2019 & Journal of Chemical Education & $\begin{array}{l}\text { Determining Iron(III) Concentration in a Green Chemistry } \\
\text { Experiment Using Phyllanthus emblica (Indian Gooseberry) } \\
\text { Extract and Spectrophotometry }\end{array}$ & [225] \\
\hline S165 & Reed, S.M.; Hutchison, J.E. & 2000 & Journal of Chemical Education & $\begin{array}{l}\text { Green Chemistry in the Organic Teaching Laboratory: } \\
\text { An Environmentally Benign Synthesis of Adipic Acid }\end{array}$ & [67] \\
\hline S166 & $\begin{array}{l}\text { Reilly, M.K., King, R.P., Wagner, A.J. } \\
\text { and King, S.M. }\end{array}$ & 2014 & Journal of Chemical Education & $\begin{array}{l}\text { Microwave-Assisted Esterification: A Discovery-Based } \\
\text { Microscale Laboratory Experiment }\end{array}$ & [226] \\
\hline S168 & Ribeiro, M.G.T.C.; Machado, A.A.S.C. & 2013 & Green Chemistry Letters and Reviews & $\begin{array}{l}\text { Greenness of chemical reactions-limitations of } \\
\text { mass metrics }\end{array}$ & [227] \\
\hline S169 & $\begin{array}{l}\text { Ribeiro, M.G.T.C.; Costa, D.A.; } \\
\text { Machado, A.A.S.C. }\end{array}$ & 2010 & Green Chemistry Letters and Reviews & $\begin{array}{l}\text { "Green Star": A holistic green chemistry metric for } \\
\text { evaluation of teaching laboratory experiments }\end{array}$ & {$[38]$} \\
\hline S170 & $\begin{array}{l}\text { Rosatella, A.A.; Afonso, C.A.M.; } \\
\text { Branco, L.C. }\end{array}$ & 2010 & Journal of Chemical Education & $\begin{array}{l}\text { Oxidation of cyclohexene to trans-1,2-cyclohexanediol } \\
\text { promoted by p-toluenesulfonic acid without } \\
\text { organic solvents }\end{array}$ & [228] \\
\hline S171 & Rubner, I.; Berry, A.J.; Grofe, T.; Oetken, M. & 2019 & Journal of Chemical Education & $\begin{array}{l}\text { Educational Modules on the Power-to-Gas Concept } \\
\text { Demonstrate a Path to Renewable Energy Futures }\end{array}$ & [229] \\
\hline S172 & $\begin{array}{l}\text { Salman Ashraf S.; Rauf, M.A.; } \\
\text { Abdullah, F.H. }\end{array}$ & 2012 & Research in Science and Technological Education & $\begin{array}{l}\text { A hands-on approach to teaching environmental awareness } \\
\text { and pollutant remediation to undergraduate } \\
\text { chemistry students }\end{array}$ & [230] \\
\hline S173 & Samet, C.; Valiyaveettil, S. & 2018 & Journal of Chemical Education & $\begin{array}{l}\text { Fruit and Vegetable Peels as Efficient Renewable } \\
\text { Adsorbents for Removal of Pollutants from Water: A } \\
\text { Research Experience for General Chemistry Students }\end{array}$ & [231] \\
\hline S174 & Sampaio, C.I.; Sousa, L.F.; Dias, A.M. & 2020 & Journal of Chemical Education & $\begin{array}{l}\text { Separation of Anthocyaninic and Nonanthocyaninic } \\
\text { Flavonoids by Liquid-Liquid Extraction Based on Their } \\
\text { Acid-Base Properties: A Green Chemistry Approach }\end{array}$ & [232] \\
\hline S175 & Santandrea, J.; Kairouz, V.; Collins, S.K. & 2018 & Journal of Chemical Education & $\begin{array}{l}\text { Continuous Flow Science in an Undergraduate Teaching } \\
\text { Laboratory: Photocatalytic Thiol-Ene Reaction Using } \\
\text { Visible Light }\end{array}$ & [233] \\
\hline
\end{tabular}


Table A1. Cont.

\begin{tabular}{|c|c|c|c|c|c|}
\hline Paper Code & Author(s) & Year & Name of Journal & Title & Ref. \\
\hline S176 & $\begin{array}{l}\text { Schaber, P.M.; Larkin, J.E.; Pines, H.A.; } \\
\text { Berchou, K.; Wierchowski, E.; Marconi, A.; } \\
\text { Suriani, A. }\end{array}$ & 2012 & Journal of Chemical Education & $\begin{array}{l}\text { Supercritical fluid extraction versus traditional solvent } \\
\text { extraction of caffeine from tea leaves: A laboratory-based } \\
\text { case study for an organic chemistry course }\end{array}$ & [234] \\
\hline S177 & $\begin{array}{l}\text { Schneiderman, D.K.; Gilmer, C.; } \\
\text { Wentzel, M.T.; Martello, M.T.; Kubo, T.; } \\
\text { Wissinger, J.E. }\end{array}$ & 2014 & Journal of Chemical Education & $\begin{array}{l}\text { Sustainable polymers in the organic chemistry laboratory: } \\
\text { Synthesis and characterization of a renewable polymer } \\
\text { from } \delta \text {-decalactone and L-lactide }\end{array}$ & [235] \\
\hline S178 & Serafin, M.; Priest, O.P. & 2015 & Journal of Chemical Education & $\begin{array}{l}\text { Identifying Passerini products using a green, } \\
\text { guided-inquiry, collaborative approach combined with } \\
\text { spectroscopic lab techniques }\end{array}$ & [236] \\
\hline S179 & $\begin{array}{l}\text { Sharma, R.K., Yadav, S., Gupta, R. } \\
\text { and Arora, G. }\end{array}$ & 2019 & Journal of Chemical Education & $\begin{array}{l}\text { Synthesis of Magnetic Nanoparticles Using Potato Extract } \\
\text { for Dye Degradation: A Green Chemistry Experiment }\end{array}$ & [237] \\
\hline S180 & Sharma, R.K.; Gulati, S.; Mehta, S. & 2012 & Journal of Chemical Education & $\begin{array}{l}\text { Preparation of gold nanoparticles using tea: A green } \\
\text { chemistry experiment }\end{array}$ & {$[41]$} \\
\hline S181 & Sharma, R.K.; Sharma, C.; Sidhwani, I.T. & 2011 & Journal of Chemical Education & $\begin{array}{l}\text { Solventless and one-pot synthesis of } \mathrm{Cu}(\mathrm{II}) \text { phthalocyanine } \\
\text { complex: A green chemistry experiment }\end{array}$ & [238] \\
\hline S183 & $\begin{array}{l}\text { Shimizu, E.A.; Cory, B.; Hoang, J.; } \\
\text { Castro, G.G.; Jung, M.E.; Vosburg, D.A. }\end{array}$ & 2019 & Journal of Chemical Education & $\begin{array}{l}\text { Aqueous Dearomatization/Diels-Alder Cascade to a } \\
\text { Grandifloracin Precursor }\end{array}$ & [240] \\
\hline S184 & Silveira, G.; Ikegaki, M.; Schneedorf, J.M. & 2017 & Green Chemistry Letters and Reviews & $\begin{array}{l}\text { A low-cost yeast-based biofuel cell: An educational } \\
\text { green approach }\end{array}$ & [241] \\
\hline S185 & Silverman, J.R.; Hudson, R. & 2020 & Journal of Chemical Education & $\begin{array}{l}\text { Evaluating Feedstocks, Processes, and Products in the } \\
\text { Teaching Laboratory: A Framework for Students to Use } \\
\text { Metrics to Design Greener Chemistry Experiments }\end{array}$ & {$[54]$} \\
\hline S186 & Silverman, J.R. & 2016 & Journal of Chemical Education & $\begin{array}{l}\text { Biobased Organic Chemistry Laboratories as Sustainable } \\
\text { Experiment Alternatives }\end{array}$ & [242] \\
\hline S187 & Simeonov, S.P.; Afonso, C.A.M. & 2013 & Journal of Chemical Education & $\begin{array}{l}\text { Batch and flow synthesis of 5-hydroxymethylfurfural } \\
\text { (HMF) from fructose as a bioplatform intermediate: An } \\
\text { experiment for the organic or analytical laboratory }\end{array}$ & [243] \\
\hline
\end{tabular}


Table A1. Cont.

\begin{tabular}{|c|c|c|c|c|c|}
\hline Paper Code & Author(s) & Year & Name of Journal & Title & Ref. \\
\hline S188 & $\begin{array}{l}\text { Sims, P.A.; Branscum, K.M.; Kao, L.; } \\
\text { Keaveny, V.R. }\end{array}$ & 2010 & Journal of Chemical Education & $\begin{array}{l}\text { An inexpensive, relatively green, and rapid method to } \\
\text { purify genomic DNA from Escherichia coli: An experiment } \\
\text { for the undergraduate biochemistry laboratory }\end{array}$ & [244] \\
\hline S189 & Smith, M.K.; Angle, S.R.; Northrop, B.H. & 2015 & Journal of Chemical Education & $\begin{array}{l}\text { Preparation and analysis of cyclodextrin-based } \\
\text { metal-organic frameworks: Laboratory experiments } \\
\text { adaptable for high school through advanced } \\
\text { undergraduate students }\end{array}$ & [245] \\
\hline S191 & Sobral, A.J.F.N. & 2006 & Journal of Chemical Education & $\begin{array}{l}\text { Synthesis of meso-diethyl-2,2'-dipyrromethane in water. } \\
\text { An experiment in green organic chemistry }\end{array}$ & [247] \\
\hline S192 & $\begin{array}{l}\text { Solomon, S.D.; Rutkowsky, S.A.; } \\
\text { Mahon, M.L.; Halpern, E.M. }\end{array}$ & 2011 & Journal of Chemical Education & $\begin{array}{l}\text { Synthesis of copper pigments, malachite and verdigris: } \\
\text { Making tempera paint }\end{array}$ & [248] \\
\hline S193 & $\begin{array}{l}\text { Stacey, J.M.; Dicks, A.P.; Goodwin, A.A.; } \\
\text { Rush, B.M.; Nigam, M. }\end{array}$ & 2013 & Journal of Chemical Education & $\begin{array}{l}\text { Green carbonyl condensation reactions demonstrating } \\
\text { solvent and organocatalyst recyclability }\end{array}$ & [249] \\
\hline S195 & $\begin{array}{l}\text { Strachan, J.; Barnett, C.; Maschmeyer, T.; } \\
\text { Masters, A.F.; Motion, A; Yuen, A.K.L. }\end{array}$ & 2020 & Journal of Chemical Education & $\begin{array}{l}\text { Nanoparticles for Undergraduates: Creation, } \\
\text { Characterization, and Catalysis }\end{array}$ & [251] \\
\hline S196 & $\begin{array}{l}\text { Sues, P.E.; Cai, K.; McIntosh, D.F.; } \\
\text { Morris, R.H. }\end{array}$ & 2015 & Journal of Chemical Education & $\begin{array}{l}\text { Template effect and ligand substitution methods for the } \\
\text { synthesis of iron catalysts: A two-part experiment for } \\
\text { inorganic chemistry }\end{array}$ & [252] \\
\hline S197 & Summerton, L.; Hurst, G.A.; Clark, J.H. & 2018 & $\begin{array}{l}\text { Current Opinion in Green and } \\
\text { Sustainable Chemistry }\end{array}$ & Facilitating active learning within green chemistry & [34] \\
\hline S198 & Sutheimer, S.; Caster, J.M.; Smith, S.H. & 2015 & Journal of Chemical Education & $\begin{array}{l}\text { Green Soap: An Extraction and Saponification of } \\
\text { Avocado Oil }\end{array}$ & [253] \\
\hline
\end{tabular}


Table A1. Cont.

\begin{tabular}{|c|c|c|c|c|c|}
\hline Paper Code & Author(s) & Year & Name of Journal & Title & Ref. \\
\hline S199 & $\begin{array}{l}\text { Tallmadge, W.; Homan, M.; Ruth, C.; } \\
\text { Bilek, G. }\end{array}$ & 2004 & Chemical Health and Safety & $\begin{array}{l}\text { A local pollution prevention group collaborates with a high } \\
\text { school intermediate unit bringing the benefits of microscale } \\
\text { chemistry to high school chemistry labs in the Lake } \\
\text { Erie watershed }\end{array}$ & {$[85]$} \\
\hline S200 & $\begin{array}{l}\text { Tamburini, F.; Kelly, T.; Weerapana, E.; } \\
\text { Byers, J.A. }\end{array}$ & 2014 & Journal of Chemical Education & $\begin{array}{l}\text { Paper to Plastics: An Interdisciplinary Summer Outreach } \\
\text { Project in Sustainability }\end{array}$ & {$[22]$} \\
\hline S201 & $\begin{array}{l}\text { Teixeira, J.M.; Byers, J.N.; Perez, M.G.; } \\
\text { Holman, R.W. }\end{array}$ & 2010 & Journal of Chemical Education & $\begin{array}{l}\text { The question-driven laboratory exercise: A new pedagogy } \\
\text { applied to a green modification of grignard reagent } \\
\text { formation and reaction }\end{array}$ & {$[98]$} \\
\hline S202 & $\begin{array}{l}\text { Tian, J.; Yan, L.; Sang, A.; Yuan, H.; } \\
\text { Zheng, B.; Xiao, D. }\end{array}$ & 2014 & Journal of Chemical Education & $\begin{array}{l}\text { Microwave-Assisted Synthesis of Red-Light Emitting Au } \\
\text { Nanoclusters with the Use of Egg White }\end{array}$ & [254] \\
\hline S203 & $\begin{array}{l}\text { Timmer, B.J.J.; Schaufelberger, F.; } \\
\text { Hammarberg, D.; Franzén, J.; Ramström, O.; } \\
\text { Dinér, P. }\end{array}$ & 2018 & Journal of Chemical Education & $\begin{array}{l}\text { Simple and Effective Integration of Green Chemistry and } \\
\text { Sustainability Education into an Existing Organic } \\
\text { Chemistry Course }\end{array}$ & [255] \\
\hline S204 & $\begin{array}{l}\text { Touaibia, M.; Selka, A.; Levesque, N.A.; } \\
\text { St-Onge, P.A. }\end{array}$ & 2020 & Journal of Chemical Education & $\begin{array}{l}\text { Green hydrogenation: Solvent-free hydrogenation of } \\
\text { pinenes for an undergraduate organic chemistry laboratory }\end{array}$ & [256] \\
\hline S206 & Verdía. P.; Santamarta, F.; Tojo, E. & 2017 & Journal of Chemical Education & $\begin{array}{l}\text { Synthesis of (3-Methoxycarbonyl)coumarin in an Ionic } \\
\text { Liquid: An Advanced Undergraduate Project for } \\
\text { Green Chemistry }\end{array}$ & [258] \\
\hline S207 & $\begin{array}{l}\text { Villalba, M.M.; Leslie, R.; Davis, J.; } \\
\text { Smith, R.B. }\end{array}$ & 2011 & Journal of Science Education & $\begin{array}{l}\text { Designer experiments to assist in the teaching of NMR } \\
\text { spectroscopy. A spectroscopic experiment in } \\
\text { green chemistry }\end{array}$ & [259] \\
\hline S208 & Villanueva, O.; Zimmermann, K. & 2020 & Journal of Chemical Education & $\begin{array}{l}\text { Transitioning an Upper-Level, Integrated Laboratory } \\
\text { Course to Remote and Online Instruction during the } \\
\text { COVID-19 Pandemic }\end{array}$ & {$[18]$} \\
\hline S209 & Virot, M.; Tomao, V.; Ginies, C.; Chemat, F. & 2008 & Chromatographia & $\begin{array}{l}\text { Total lipid extraction of food using d-limonene as an } \\
\text { alternative to n-hexane }\end{array}$ & [260] \\
\hline
\end{tabular}


Table A1. Cont.

\begin{tabular}{|c|c|c|c|c|c|}
\hline Paper Code & Author(s) & Year & Name of Journal & Title & Ref. \\
\hline S210 & Vogelzang, J.; Admiraal, W.F.; Van Driel, J.H. & 2020 & Chemistry Education Research and Practice & $\begin{array}{l}\text { Effects of Scrum methodology on students' critical scientific } \\
\text { literacy: the case of Green Chemistry }\end{array}$ & [261] \\
\hline S211 & $\begin{array}{l}\text { Von Dollen, J.; Oliva, S.; Max, S.; } \\
\text { Esbenshade, J. }\end{array}$ & 2018 & Journal of Chemical Education & Recovery of Silver Nitrate from Silver Chloride Waste & [262] \\
\hline S212 & $\begin{array}{l}\text { Wagner, E.P.; Koehle, M.A.; Moyle, T.M.; } \\
\text { Lambert, P.D. }\end{array}$ & 2010 & Journal of Chemical Education & $\begin{array}{l}\text { How green is your fuel? Creation and comparison of } \\
\text { automotive biofuels }\end{array}$ & [263] \\
\hline S213 & Wang, X.; Chrzanowski, M.; Liu, Y. & 2020 & Journal of Chemical Education & $\begin{array}{l}\text { Ultrasonic-Assisted Transesterification: A Green Miniscale } \\
\text { Organic Laboratory Experiment }\end{array}$ & [264] \\
\hline S214 & Wang, Y.; Zhang, M.; Hu, Y. & 2010 & Journal of Chemical Education & $\begin{array}{l}\text { Foam fractionation of lycopene: An undergraduate } \\
\text { chemistry experiment }\end{array}$ & [265] \\
\hline S215 & Wardencki, W.; Curyło, J.; Namieśnik, J. & 2005 & Polish Journal of Environmental Studies & Green chemistry-Current and future issues & [53] \\
\hline S216 & $\begin{array}{l}\text { Weires. N.A.; Johnston, A.; Warner, D.L.; } \\
\text { McCormick, M.M.; Hammond, K.; } \\
\text { McDougal, O.M. }\end{array}$ & 2013 & Journal of Chemical Education & Recycling of Waste Acetone by Fractional Distillation & [266] \\
\hline S217 & Williamson, C.L.; Maly, K.E.; Macneil, S.L. & 2013 & Journal of Chemical Education & $\begin{array}{l}\text { Synthesis of imidazolium room-temperature ionic liquids: } \\
\text { A follow-up to the procedure of Dzyuba, Kollar, and Sabnis }\end{array}$ & [267] \\
\hline S218 & Winter, R.T.; Van Beek, H.L.; Fraaije, M.W. & 2012 & Journal of Chemical Education & The nose knows: Biotechnological production of vanillin & [268] \\
\hline S219 & Wixtrom, A.; Buhler, J.; Abdel-Fattah, T. & 2014 & Journal of Chemical Education & $\begin{array}{l}\text { Mechanochemical Synthesis of Two Polymorphs of the } \\
\text { Tetrathiafulvalene-Chloranil Charge Transfer Salt: An } \\
\text { Experiment for Organic Chemistry }\end{array}$ & [269] \\
\hline S220 & $\begin{array}{l}\text { Worley, B.; Villa, E.M.; Gunn, J.M.; } \\
\text { Mattson, B. }\end{array}$ & 2019 & Journal of Chemical Education & $\begin{array}{l}\text { Visualizing Dissolution, Ion Mobility, and Precipitation } \\
\text { through a Low-Cost, Rapid-Reaction Activity Introducing } \\
\text { Microscale Precipitation Chemistry }\end{array}$ & [270] \\
\hline S221 & Wu, K.; Yu, L.; Ding, J. & 2020 & Journal of Chemical Education & $\begin{array}{l}\text { Synthesis of PCL-PEG-PCL Triblock Copolymer via } \\
\text { Organocatalytic Ring-Opening Polymerization and Its } \\
\text { Application as an Injectable Hydrogel-An } \\
\text { Interdisciplinary Learning Trial }\end{array}$ & [271] \\
\hline S222 & $\begin{array}{l}\text { Wu, N.; Kubo, T.; Sekoni, K.N.; Hall, A.O.; } \\
\text { Phadke, S.; Zurcher, D.M.; Wallace, R.L.; } \\
\text { Kothari, D.B.; McNeil, A.J. }\end{array}$ & 2019 & Journal of Chemical Education & $\begin{array}{l}\text { Student-Designed Green Chemistry Experiment for a } \\
\text { Large-Enrollment, Introductory Organic Laboratory Course }\end{array}$ & [272] \\
\hline
\end{tabular}


Table A1. Cont.

\begin{tabular}{|c|c|c|c|c|c|}
\hline Paper Code & Author(s) & Year & Name of Journal & Title & Ref. \\
\hline S223 & Xie, Y.; Liu, X.; Tao, M. & 2016 & Journal of Chemical Education & $\begin{array}{l}\text { Synthesizing Substituted 2-Amino-2-chromenes Catalyzed } \\
\text { by Tertiaryamine-Functionalized Polyacrylonitrile Fiber for } \\
\text { Students to Investigate Multicomponent Reactions and } \\
\text { Heterogeneous Catalysis }\end{array}$ & {$[273]$} \\
\hline S224 & Yadav, U.; Mande, H.; Ghalsasi, P. & 2012 & Journal of Chemical Education & $\begin{array}{l}\text { Nitration of phenols using } \mathrm{Cu}\left(\mathrm{NO}_{3}\right)_{2} \text { : Green chemistry } \\
\text { laboratory experiment }\end{array}$ & {$[40]$} \\
\hline S225 & $\begin{array}{l}\text { Zhou, H.; Zhan, W.; Wang, L.; Guo, L.; } \\
\text { Liu, Y. }\end{array}$ & 2018 & Journal of Chemical Education & $\begin{array}{l}\text { Making Sustainable Biofuels and Sunscreen from Corncobs } \\
\text { to Introduce Students to Integrated Biorefinery Concepts } \\
\text { and Techniques }\end{array}$ & {$[274]$} \\
\hline S226 & $\begin{array}{l}\text { Zuin, V.G.; Segatto, M.L.; Zandonai, D.P.; } \\
\text { Grosseli, G.M.; Stahl, A.; Zanotti, K.; } \\
\text { Andrade, R.S. }\end{array}$ & 2019 & Journal of Chemical Education & $\begin{array}{l}\text { Integrating Green and Sustainable Chemistry into } \\
\text { Undergraduate Teaching Laboratories: Closing and } \\
\text { Assessing the Loop on the Basis of a Citrus Biorefinery } \\
\text { Approach for the Biocircular Economy in Brazil }\end{array}$ & [86] \\
\hline S227 & Bumbaugh, R.E.; Ott, L.S. & 2020 & ACS Symposium Series & $\begin{array}{l}\text { Preparing and Testing Novel Deep Eutectic Solvents from } \\
\text { Biodiesel Co-Product Glycerol for Use as Green Solvents in } \\
\text { Organic Chemistry Teaching Laboratories }\end{array}$ & {$[275]$} \\
\hline S229 & $\begin{array}{l}\text { Ferhat, M.A.; Meklati, B.Y.; Visinoni, F.; } \\
\text { Vian, M.A.; Chemat, F. }\end{array}$ & 2008 & Chimica Oggi & $\begin{array}{l}\text { Solvent free microwave extraction of essential oils Green } \\
\text { chemistry in the teaching laboratory }\end{array}$ & {$[277]$} \\
\hline S230 & Kohn, C. & 2019 & Physical Sciences Reviews & $\begin{array}{l}\text { The development of a bioenergy-based green chemistry } \\
\text { curriculum for high schools }\end{array}$ & {$[278]$} \\
\hline S231 & Slater, C.S.; Savelski, M.J. & 2011 & $\begin{array}{l}\text { World Transactions on Engineering and } \\
\text { Technology Education }\end{array}$ & $\begin{array}{l}\text { Partnerships with the pharmaceutical industry to } \\
\text { promote sustainability }\end{array}$ & {$[279]$} \\
\hline S232 & Warner, M.G.; Succawa, G.L.; Hutchison, J.E. & 2001 & Green Chemistry & $\begin{array}{l}\text { Solventless syntheses of mesotetraphenylporphyrin: new } \\
\text { experiments for a greener organic chemistry } \\
\text { laboratory curriculum }\end{array}$ & [280] \\
\hline S233 & Joshi, U.J.; Gokhale, K.M.; Kanitkar, A.P. & 2011 & $\begin{array}{l}\text { Indian Journal of Pharmaceutical Education } \\
\text { and Research }\end{array}$ & Green chemistry: Need of the hour & [281] \\
\hline
\end{tabular}


Table A1. Cont.

\begin{tabular}{|c|c|c|c|c|c|}
\hline Paper Code & Author(s) & Year & Name of Journal & Title & Ref. \\
\hline $1 \mathrm{~W}$ & $\begin{array}{l}\text { Cunningham, A.D.; Ham, E.Y.; } \\
\text { Vosburg, D.A. }\end{array}$ & 2011 & Journal of Chemical Education & $\begin{array}{l}\text { Chemoselective Reactions of Citral: Green Syntheses of } \\
\text { Natural Perfumes for the Undergraduate } \\
\text { Organic Laboratory }\end{array}$ & [282] \\
\hline $2 \mathrm{~W}$ & Dicks, A.P.; Hent, A.; Koroluk, K.J. & 2018 & Green Chemistry Letters and Reviews & $\begin{array}{l}\text { The EcoScale as a framework for undergraduate green } \\
\text { chemistry teaching and assessment }\end{array}$ & [283] \\
\hline $3 \mathrm{~W}$ & Gregor, R.W.; Goj, L.A. & 2011 & Journal of Chemical Education & $\begin{array}{l}\text { Solvent-Free Synthesis of 2,2'-Dinitrobiphenyl: An } \\
\text { Ullmann Coupling in the Introductory Organic Laboratory }\end{array}$ & [284] \\
\hline $4 \mathrm{~W}$ & Lacuskova, D.; Drozdikova, A. & 2017 & Chemistry-Didactics-Ecology-Metrology & $\begin{array}{l}\text { Biocatalytic Reduction of Ketones in A Secondary School } \\
\text { Laboratory }\end{array}$ & [285] \\
\hline $5 \mathrm{~W}$ & Lee, D.B. & 2019 & Green Chemistry Letters and Reviews & $\begin{array}{l}\text { Re-casting traditional organic experiments into green } \\
\text { guided-inquiry based experiments: student perceptions }\end{array}$ & [59] \\
\hline $6 \mathrm{~W}$ & $\begin{array}{l}\text { Palesch, J.J.; Gilles, B.C.; Chycota, J.; } \\
\text { Haj, M.K.; Fahnhorst, G.W.; Wissinger, J.E. }\end{array}$ & 2019 & Green Chemistry Letters and Reviews & $\begin{array}{l}\text { Iodination of vanillin and subsequent Suzuki-Miyaura } \\
\text { coupling: two-step synthetic sequence teaching green } \\
\text { chemistry principles }\end{array}$ & [286] \\
\hline $7 \mathrm{~W}$ & $\begin{array}{l}\text { Gabriela, M.; Ribeiro, T.C.; } \\
\text { MacHado, A.A.S.C. }\end{array}$ & 2011 & Journal of Chemical Education & $\begin{array}{l}\text { Metal-Acetylacetonate Synthesis Experiments: Which } \\
\text { Is Greener? }\end{array}$ & [83] \\
\hline $8 \mathrm{~W}$ & $\begin{array}{l}\text { Rojas-Fernandez, A.G.; } \\
\text { Aguilar-Santelises, L.; Millan, M.C.; } \\
\text { Aguilar-Santelises, M.; Garcia-del Valle, A. }\end{array}$ & 2017 & $\begin{array}{l}\text { Multidisciplinary Journal for Education Social } \\
\text { and Technological Sciences }\end{array}$ & Teaching chemistry with sustainability & [287] \\
\hline $9 \mathrm{~W}$ & Tavener, S.; Hardy J.; Hart, N.; Goddard, A. & 2003 & Green chemistry & Teaching green chemistry: from lemons to lemonade bottles & [288] \\
\hline $10 \mathrm{~W}$ & Young, D.M.; Welker, J.J.C.; Doxsee, K.M. & 2011 & Journal of Chemical Education & Green Synthesis of a Fluorescent Natural Product & [289] \\
\hline $11 \mathrm{~W}$ & Houri, A.; Wehbe, H. & 2003 & Green Chemistry & $\begin{array}{l}\text { Towards an environmentally friendly chemistry laboratory: } \\
\text { managing expired chemicals }\end{array}$ & [290] \\
\hline $1 \mathrm{E}$ & van Arnum, S.D. & 2005 & Journal of Chemical Education & $\begin{array}{l}\text { An Approach towards Teaching Green } \\
\text { Chemistry Fundamentals }\end{array}$ & [291] \\
\hline $2 \mathrm{E}$ & $\begin{array}{l}\text { McKenzie, L.C.; Huffman, L.M.; } \\
\text { Hutchison, J.E.; Rogers, C.E.; Goodwin, T.E.; } \\
\text { Spessard, G.O. }\end{array}$ & 2009 & Journal of Chemical Education & $\begin{array}{l}\text { Greener "Solutions" for the Organic Chemistry Teaching } \\
\text { Lab: Exploring the Advantages of Alternative } \\
\text { Reaction Media }\end{array}$ & [292] \\
\hline
\end{tabular}


Table A1. Cont.

\begin{tabular}{|c|c|c|c|c|c|}
\hline Paper Code & Author(s) & Year & Name of Journal & Title & Ref. \\
\hline $3 \mathrm{E}$ & Dintzner, M.R.; Wucka, P.R.; Lyons, T.W. & 2006 & Journal of Chemical Education & $\begin{array}{l}\text { Microwave-Assisted Synthesis of a Natural Insecticide on } \\
\text { Basic Montmorillonite K10 Clay. Green Chemistry in the } \\
\text { Undergraduate Organic Laboratory }\end{array}$ & [293] \\
\hline $4 \mathrm{E}$ & $\begin{array}{l}\text { Stark, A.; Ott, D.; Kralisch, D.; Kreisel, G.; } \\
\text { Ondruschka, B. }\end{array}$ & 2010 & Journal of Chemical Education & Ionic Liquids and Green Chemistry: A Lab Experiment & [294] \\
\hline $5 \mathrm{E}$ & $\begin{array}{l}\text { Ravia, S.; Gamenara, D.; Schapiro, V.; } \\
\text { Bellomo, A.; Adum, J.; Seoane, G.; } \\
\text { Gonzalez, D. }\end{array}$ & 2006 & Journal of Chemical Education & $\begin{array}{l}\text { Enantioselective Reduction by Crude Plant Parts: } \\
\text { Reduction of Benzofuran-2-yl Methyl Ketone with Carrot } \\
\text { ("Daucus carota") Bits }\end{array}$ & [295] \\
\hline $6 \mathrm{E}$ & $\begin{array}{l}\text { Ribeiro, M.G.T.C.; Yunes, S.F.; } \\
\text { Machado, A.A.S.C. }\end{array}$ & 2014 & Journal of Chemical Education & $\begin{array}{l}\text { Assessing the Greenness of Chemical Reactions in the } \\
\text { Laboratory Using Updated Holistic Graphic Metrics Based } \\
\text { on the Globally Harmonized System of Classification and } \\
\text { Labelling of Chemicals }\end{array}$ & [296] \\
\hline 7E & Armenta, S.; de la Guardia, M. & 2011 & Journal of Chemical Education & $\begin{array}{l}\text { Determination of Mercury in Milk by Cold Vapor Atomic } \\
\text { Fluorescence: A Green Analytical Chemistry } \\
\text { Laboratory Experiment }\end{array}$ & [297] \\
\hline $8 \mathrm{E}$ & Sauvage, X.; Delaude, L. & 2008 & Journal of Chemical Education & $\begin{array}{l}\text { The Synthesis of “N"-Benzyl-2-Azanorbornene via } \\
\text { Aqueous Hetero Diels-Alder Reaction: An Undergraduate } \\
\text { Project in Organic Synthesis and Structural Analysis }\end{array}$ & [298] \\
\hline $9 \mathrm{E}$ & Hooper, M.M.; DeBoef, B. & 2009 & Journal of Chemical Education & $\begin{array}{l}\text { A Green Multicomponent Reaction for the Organic } \\
\text { Chemistry Laboratory: The Aqueous Passerini Reaction }\end{array}$ & [299] \\
\hline $10 \mathrm{E}$ & $\begin{array}{l}\text { Phonchaiya, S.; Panijpan, B.; Rajviroongit, S.; } \\
\text { Wright, T.; Blanchfield, J.T. }\end{array}$ & 2009 & Journal of Chemical Education & $\begin{array}{l}\text { A Facile Solvent-Free Cannizzaro Reaction: An } \\
\text { Instructional Model for Introductory Organic } \\
\text { Chemistry Laboratory }\end{array}$ & [300] \\
\hline $11 \mathrm{E}$ & Ballard, C.E. & 2010 & Journal of Chemical Education & $\begin{array}{l}\text { pH-Controlled Oxidation of an Aromatic Ketone: } \\
\text { Structural Elucidation of the Products of Two Green } \\
\text { Chemical Reactions }\end{array}$ & [301] \\
\hline $12 \mathrm{E}$ & Tundo, P.; Rosamilia, A.E.; Arico, F. & 2010 & Journal of Chemical Education & $\begin{array}{l}\text { Methylation of 2-Naphthol Using Dimethyl Carbonate } \\
\text { under Continuous-Flow Gas-Phase Conditions }\end{array}$ & [302] \\
\hline $13 \mathrm{E}$ & $\begin{array}{l}\text { Akers, Stephen M.; Conkle, Jeremy L.; } \\
\text { Thomas, Stephanie N.; Rider, Keith B. }\end{array}$ & 2006 & Journal of Chemical Education & $\begin{array}{l}\text { Determination of the Heat of Combustion of Biodiesel } \\
\text { Using Bomb Calorimetry: A Multidisciplinary } \\
\text { Undergraduate Chemistry Experiment }\end{array}$ & [303] \\
\hline $14 \mathrm{E}$ & $\begin{array}{l}\text { Lazarski, K.E.; Rich, A.A.; } \\
\text { Mascarenhas, C.M. }\end{array}$ & 2008 & Journal of Chemical Education & $\begin{array}{l}\text { A One-Pot, Asymmetric Robinson Annulation in the } \\
\text { Organic Chemistry Majors Laboratory }\end{array}$ & [304] \\
\hline
\end{tabular}


Table A1. Cont.

\begin{tabular}{|c|c|c|c|c|c|}
\hline Paper Code & Author(s) & Year & Name of Journal & Title & Ref. \\
\hline $15 \mathrm{E}$ & Sidhwani, I.T.; Chowdhury, S. & 2008 & Journal of Chemical Education & $\begin{array}{l}\text { Greener Alternative to Qualitative Analysis for Cations } \\
\text { without } \mathrm{H}_{2} \mathrm{~S} \text { and Other Sulfur-Containing Compounds }\end{array}$ & [305] \\
\hline $16 \mathrm{E}$ & Eby, E.; Deal, S.T. & 2008 & Journal of Chemical Education & $\begin{array}{l}\text { Aromatic Substitution for the Organic } \\
\text { Chemistry Laboratory }\end{array}$ & [306] \\
\hline $17 \mathrm{E}$ & Andraos, J.; Sayed, M. & 2007 & Journal of Chemical Education & $\begin{array}{l}\text { On the Use of "Green" Metrics in the Undergraduate } \\
\text { Organic Chemistry Lecture and Lab to Assess the Mass } \\
\text { Efficiency of Organic Reactions }\end{array}$ & {$[35]$} \\
\hline $19 \mathrm{E}$ & $\begin{array}{l}\text { Santos, E.S.; Garcia, G.; Cruz, I.; Gomez, L.; } \\
\text { Florencia, E. }\end{array}$ & 2004 & Journal of Chemical Education & $\begin{array}{l}\text { Caring for the Environment while Teaching } \\
\text { Organic Chemistry }\end{array}$ & [308] \\
\hline
\end{tabular}




\section{References}

1. UNESCO Institute for Statistics. School Closures and Regional Policies to Mitigate Learning Loss due to COVID-19: A Focus on the Asia-Pacific. Available online: https:/ / unesdoc.unesco.org/ark:/48223/pf0000378429/PDF/378429eng.pdf.multi (accessed on 21 September 2021).

2. United Nations Sustainable Development Knowledge Platform. Transforming Our World: The 2030 Agenda for Sustainable Development. Available online: https://sdgs.un.org/sites/default/files/publications/21252030AgendaforSustainableDevelopmentweb.pdf (accessed on 21 September 2021).

3. United Nations Sustainable Development Knowledge Platform. COVID-19 Recovery: Implications for the Decade of Action. Available online: https://sdgs.un.org/events/green-economy-covid-19-recovery-implications-decade-action-27340 (accessed on 21 September 2021).

4. United Nations Sustainable Development Knowledge Platform. Sustainable Development Goals, 4th Goal: Quality Education. Available online: https:/ /www.un.org/sustainabledevelopment/education/ (accessed on 21 September 2021).

5. SDG Knowledge Hub Platform. As Decade of Action Has Become a Decade of Recovery, HLPF Focuses on Pandemic Response. Available online: https://sdg.iisd.org/news/as-decade-of-action-has-become-a-decade-of-recovery-hlpf-focuses-on-pandemicresponse/ (accessed on 21 September 2021).

6. ACS Committee on Environmental Improvement. Available online: https://www.acs.org/content/acs/en/about/governance/ committees / cei.html (accessed on 21 September 2021).

7. ACS Committee on Professional Training. Available online: https://www.acs.org/content/acs/en/about/governance/ committees / training.html (accessed on 21 September 2021).

8. KTH, Royal Institute of Technology. Available online: https://intra.kth.se/en/styrning/miljo-hallbar-utveckling/policy-forhallbar-utveckling-for-kth-1.553616 (accessed on 21 September 2021).

9. Anastas, P.T.; Warner, J.C. Green Chemistry: Theory and Practice; Oxford University Press: New York, NY, USA, 1998.

10. ACS. What Is Green Chemistry? Available online: https://www.acs.org/content/acs/en/greenchemistry/what-is-greenchemistry.html (accessed on 21 September 2021).

11. Haack, J.A.; Hutchison, J.E.; Kirchhoff, M.M.; Levy, I.J. Going Green: Lecture Assignments and Lab Experiences for the College Curriculum. J. Chem. Educ. 2005, 82, 974-976. [CrossRef]

12. Andraos, J.; Dicks, A.P. Green Chemistry Teaching in Higher Education: A Review of Effective Practices. Chem. Educ. Res. Pract. 2012, 13, 69-79. [CrossRef]

13. Collins, T.J. Introducing Green Chemistry in Teaching and Research. J. Chem. Educ. 1995, 72, 965-966. [CrossRef]

14. Braun, B.; Charney, R.; Clarens, A.; Farrugia, J.; Kitchens, C.; Lisowski, C.; Naistat, D.; O’Neil, A. Completing Our Education. Green Chemistry in the Curriculum. J. Chem. Educ. 2006, 83, 1126. [CrossRef]

15. Eilks, I.; Rauch, F. Sustainable Development and Green Chemistry in Chemistry Education. Chem. Educ. Res. Pract. 2012, 13, 57-58. [CrossRef]

16. Listyarini, R.V.; Pamenang, F.D.N.; Harta, J.; Wijayanti, L.W.; Asy'ari, M.; Lee, W. The Integration of Green Chemistry Principles into Small Scale Chemistry Practicum for Senior High School Students. J. Pendidik. IPA Indones. 2019, 8, 371-378. [CrossRef]

17. Avsec, S.; Jagiełło-Kowalczyk, M. Investigating Possibilities of Developing Self-Directed Learning in Architecture Students Using Design Thinking. Sustainability 2021, 13, 4369. [CrossRef]

18. Villanueva, O.; Zimmermann, K. Transitioning an Upper-Level, Integrated Laboratory Course to Remote and Online Instruction during the COVID-19 Pandemic. J. Chem. Educ. 2020, 97, 3114-3120. [CrossRef]

19. Avsec, S.; Ferk Savec, V. Pre-Service Teachers' Perceptions of, and Experiences with, Technology-Enhanced Transformative Learning towards Education for Sustainable Development. Sustainability 2021, 13, 10443. [CrossRef]

20. Colmenares, J.C.; Arévalo-García, E.B.; Colmenares-Quintero, R. A Simple Method of Water Purification and Energy Extraction from Organic Wastewater: An Application of Green Chemistry Principles in Everyday Life. J. Sci. Educ. 2015, 16, 17-19.

21. Hudson, R.; Ackerman, H.M.; Gallo, L.K.; Gwinner, A.S.; Krauss, A.; Sears, J.D.; Bishop, A.; Esdale, K.N.; Katz, J.L. CO 2 Dry Cleaning: A Benign Solvent Demonstration Accessible to K-8 Audiences. J. Chem. Educ. 2017, 94, 480-482. [CrossRef]

22. Tamburini, F.; Kelly, T.; Weerapana, E.; Byers, J.A. Paper to Plastics: An Interdisciplinary Summer Outreach Project in Sustainability. J. Chem. Educ. 2014, 91, 1574-1579. [CrossRef]

23. Hoffman, K.C.; Dicks, A.P. Shifting the Paradigm of Chemistry Education by Greening the High School Laboratory. Sustain. Chem. Pharm. 2020, 16, 100242. [CrossRef]

24. Kolopajlo, L. Green Chemistry Pedagogy. Phys. Sci. Rev. 2017, 2, 1-17. [CrossRef]

25. Kümmerer, K.; Clark, J.H.; Zuin, V.G. Rethinking Chemistry for a Circular Economy. Science 2020, 367, 369-370. [CrossRef]

26. Zuin, V.G.; Eilks, I.; Elschami, M.; Kümmerer, K. Education in Green Chemistry and in Sustainable Chemistry: Perspectives towards Sustainability. Green Chem. 2021, 23, 1594-1608. [CrossRef]

27. Aubrecht, K.B.; Bourgeois, M.; Brush, E.J.; Mackellar, J.; Wissinger, J.E. Integrating Green Chemistry in the Curriculum: Building Student Skills in Systems Thinking, Safety, and Sustainability. J. Chem. Educ. 2019, 96, 2872-2880. [CrossRef] 
28. Armstrong, L.B.; Rivas, M.C.; Zhou, Z.; Irie, L.M.; Kerstiens, G.A.; Robak, M.A.T.; Douskey, M.C.; Baranger, A.M. Developing a Green Chemistry Focused General Chemistry Laboratory Curriculum: What Do Students Understand and Value about Green Chemistry? J. Chem. Educ. 2019, 96, 2410-2419. [CrossRef]

29. Smith, J.G. Organic Chemistry, 3rd ed.; McGraw-Hill: New York, NY, USA, 2011.

30. McMurry, J. Organic Chemistry, 8th ed.; Brooks/Cole: Belmont, CA, USA, 2012.

31. Ahluwalia, V.K. Green Chemistry: A Textbook; Alpha Science International: Oxford, UK, 2012.

32. Gross, E.M. Green Chemistry and Sustainability: An Undergraduate Course for Science and Nonscience Majors. J. Chem. Educ. 2013, 90, 429-431. [CrossRef]

33. Dicks, A.P. Green Organic Chemistry in Lecture and Laboratory, 1st ed.; CRC Press: Boca Raton, FL, USA, 2012. [CrossRef]

34. Summerton, L.; Hurst, G.A.; Clark, J.H. Facilitating Active Learning within Green Chemistry. Curr. Opin. Green Sustain. Chem. 2018, 13, 56-60. [CrossRef]

35. Andraos, J.; Sayed, M. On the Use of "Green" Metrics in the Undergraduate Organic Chemistry Lecture and Lab to Assess the Mass Efficiency of Organic Reactions. J. Chem. Educ. 2007, 84, 1004-1010. [CrossRef]

36. Calvo-Flores, F.G. Sustainable Chemistry Metrics. ChemSusChem 2009, 2, 905-919. [CrossRef] [PubMed]

37. Laird, T. Green Chemistry Is Good Process Chemistry. Org. Process. Res. Dev. 2012, 16, 1-2. [CrossRef]

38. Ribeiro, M.G.T.C.; Costa, D.A.; Machado, A.A.S.C. "Green Star": A Holistic Green Chemistry Metric for Evaluation of Teaching Laboratory Experiments. Green Chem. Lett. Rev. 2010, 3, 149-159. [CrossRef]

39. Karpudewan, M.; Ismail, Z.H.; Mohamed, N. The Integration of Green Chemistry Experiments with Sustainable Development Concepts in Pre-Service Teachers' Curriculum: Experiences from Malaysia. Int. J. Sustain. High. Educ. 2009, 10, 118-135. [CrossRef]

40. Yadav, U.; Mande, H.; Ghalsasi, P. Nitration of Phenols Using $\mathrm{Cu}\left(\mathrm{NO}_{3}\right)_{2}$ : Green Chemistry Laboratory Experiment. J. Chem. Educ. 2012, 89, 268-270. [CrossRef]

41. Sharma, R.K.; Gulati, S.; Mehta, S. Preparation of Gold Nanoparticles Using Tea: A Green Chemistry Experiment. J. Chem. Educ. 2012, 89, 1316-1318. [CrossRef]

42. Abraham, L.; Stachow, L.; Du, H. Cinnamon Oil: An Alternate and Inexpensive Resource for Green Chemistry Experiments in Organic Chemistry Laboratory. J. Chem. Educ. 2020, 97, 3797-3805. [CrossRef]

43. Blosser, B.F. The Role of the Laboratory in Science Teaching. Sch. Sci. Math. 1983, 83, 165-169. [CrossRef]

44. Hofstein, A.; Lunetta, V.N. The Laboratory in Science Education: Foundations for the Twenty-First Century. Sci. Educ. 2004, 88, 28-54. [CrossRef]

45. Hofstein, A. The Laboratory in Chemistry Education: Thirty Years of Experience With Developments, Implementation, and Research Laboratory Activities Have Long Had a Distinctive and Central Role in the Science to Quote from Ira Ramsen (1846-1927), Who Wrote His Me. Chem. Educ. Res. Pract. 2004, 5, 247-264. [CrossRef]

46. Hofstein, A.; Navon, O.; Kipnis, M.; Mamlok-Naaman, R. Developing Students' Ability to Ask More and Better Questions Resulting from Inquiry-Type Chemistry Laboratories. J. Res. Sci. Teach. 2005, 42, 791-806. [CrossRef]

47. Abrahams, I.; Millar, R. Does Practical Work Really Work? A Study of the Effectiveness of Practical Work as a Teaching and Learning Method in School Science. Int. J. Sci. Educ. 2008, 30, 1945-1969. [CrossRef]

48. Logar, A.; Savec, V.F. Students' Hands-on Experimental Work vs Lecture Demonstration in Teaching Elementary School Chemistry. Acta Chim. Slov. 2011, 58, 866-875.

49. Wei, B.; Liu, H. An Experienced Chemistry Teacher's Practical Knowledge of Teaching with Practical Work: The PCK Perspective. Chem. Educ. Res. Pract. 2018, 19, 452-462. [CrossRef]

50. Millar, R.; Le Marechal, J.-F.; Tiberghien, A. "Mapping" the Domain-Varieties of Practical Work. In Practical Work in Science Education—Recent Research Studies; Leach, J., Paulsen, A., Eds.; Roskilde University Press/Kluwer: Dordrecht, The Netherlands, 1999; pp. 33-59.

51. Millar, R.; Leach, J.; Osborne, J. Improving Science Education: The Contribution of Research; McGraw-Hill Education: London, UK, 2003; Volume 30, pp. 130-135.

52. Płotka-Wasylka, J.; Kurowska-Susdorf, A.; Sajid, M.; de la Guardia, M.; Namieśnik, J.; Tobiszewski, M. Green Chemistry in Higher Education: State of the Art, Challenges, and Future Trends. ChemSusChem 2018, 11, 2845-2858. [CrossRef]

53. Wardencki, W.; Curyło, J.; Namieśnik, J. Green Chemistry-Current and Future Issues. Polish J. Environ. Stud. 2005, 14, 389-395.

54. Silverman, J.R.; Hudson, R. Evaluating Feedstocks, Processes, and Products in the Teaching Laboratory: A Framework for Students to Use Metrics to Design Greener Chemistry Experiments. J. Chem. Educ. 2020, 97, 390-401. [CrossRef]

55. Dicks, A.P. Teaching Reaction Efficiency through the Lens of Green Chemistry: Should Students Focus on the Yield, or the Process? Curr. Opin. Green Sustain. Chem. 2018, 13, 27-31. [CrossRef]

56. Dicks, A.P. Solvent-Free Reactivity in the Undergraduate Organic Laboratory. Green Chem. Lett. Rev. 2009, 2, 87-100. [CrossRef]

57. Dicks, A.P. A Review of Aqueous Organic Reactions for the Undergraduate Teaching Laboratory. Green Chem. Lett. Rev. 2009, 2, 9-21. [CrossRef]

58. Narayan, S. Sustainability and Some Green Initiatives in Undergraduate Education. Phys. Sci. Rev. 2020, 5, 1-16. [CrossRef]

59. Lee, D.B. Re-Casting Traditional Organic Experiments into Green Guided-Inquiry Based Experiments: Student Perceptions. Green Chem. Lett. Rev. 2019, 12, 107-116. [CrossRef] 
60. Page, M.J.; McKenzie, J.E.; Bossuyt, P.M.; Boutron, I.; Hoffmann, T.C.; Mulrow, C.D.; Shamseer, L.; Tetzlaff, J.M.; Akl, E.A.; Brennan, S.E.; et al. The PRISMA 2020 Statement: An Updated Guideline for Reporting Systematic Reviews. PLoS Med. 2021, 18, 1-15. [CrossRef] [PubMed]

61. Hinojo-Lucena, F.J.; Aznar-Díaz, I.; Cáceres-Reche, M.P.; Trujillo-Torres, J.M.; Romero-Rodríguez, J.M. Problematic internet use as a predictor of eating disorders in students: A systematic review and meta-analysis study. Nutrients 2019, 11, 2151. [CrossRef] [PubMed]

62. Salisbury, L. Web of Science and Scopus: A Comparative Review of Content and Searching Capabilities. Charlest. Advis. 2009, 11, 5-18.

63. Kalogiannakis, M.; Papadakis, S.; Zourmpakis, A.I. Gamification in Science Education. A Systematic Review of the Literature. Educ. Sci. 2021, 11, 22. [CrossRef]

64. Vojír, K.; Rusek, M. Science Education Textbook Research Trends: A Systematic Literature Review. Int. J. Sci. Educ. 2019, 41, 1496-1516. [CrossRef]

65. Page, M.J.; McKenzie, J.E.; Bossuyt, P.M.; Boutron, I.; Hoffmann, T.C.; Mulrow, C.D.; Shamseer, L.; Tetzlaff, J.M.; Akl, E.A.; Brennan, S.E.; et al. The PRISMA 2020 Statement: An Updated Guideline for Reporting Systematic Reviews. BMJ 2021, $372,2021$. [CrossRef]

66. Abelha, M.; Fernandes, S.; Mesquita, D.; Seabra, F.; Ferreira-Oliveira, A.T. Graduate Employability and Competence Development in Higher Education-A Systematic Literature Review Using PRISMA. Sustainability 2020, 12, 5900. [CrossRef]

67. Reed, S.M.; Hutchison, J.E. Green Chemistry in the Organic Teaching Laboratory: An Environmentally Benign Synthesis of Adipic Acid. J. Chem. Educ. 2000, 77, 1627-1629. [CrossRef]

68. Marques, C.A.; Marcelino, L.V.; Dias, É.D.S.; Rüntzel, P.L.; Souza, L.C.A.B.; Machado, A. Green Chemistry Teaching for Sustainability in Papers Published by the Journal of Chemical Education. Quim. Nova 2020, 43, 1510-1521. [CrossRef]

69. Academic Accelerator. Available online: https://academic-accelerator.com/ (accessed on 19 September 2021).

70. Buckley, H.L.; Beck, A.R.; Mulvihill, M.J.; Douskey, M.C. Fitting It All in: Adapting a Green Chemistry Extraction Experiment for Inclusion in an Undergraduate Analytical Laboratory. J. Chem. Educ. 2013, 90, 771-774. [CrossRef]

71. Cardinal, P.; Greer, B.; Luong, H.; Tyagunova, Y. A Multistep Synthesis Incorporating a Green Bromination of an Aromatic Ring. J. Chem. Educ. 2012, 89, 1061-1063. [CrossRef]

72. Duangpummet, P.; Chaiyen, P.; Chenprakhon, P. Lipase-Catalyzed Esterification: An Inquiry-Based Laboratory Activity To Promote High School Students' Understanding and Positive Perceptions of Green Chemistry. J. Chem. Educ. 2019, 96, 1205-1211. [CrossRef]

73. Garner, N.; Siol, A.; Eilks, I. The Synthesis of Vanillin-Learning about Aspects of Sustainable Chemistry by Comparing Different Syntheses. J. Sci. Educ. 2016, 17, 25-28.

74. Ginzburg, A.L.; Baca, N.A.; Hampton, P.D. The Isomerization of (-)-Menthone to (+)-Isomenthone Catalyzed by an Ion-Exchange Resin. J. Chem. Educ. 2014, 91, 1748-1750. [CrossRef]

75. Graham, K.J.; Jones, T.N.; Schaller, C.P.; McIntee, E.J. Implementing a Student-Designed Green Chemistry Laboratory Project in Organic Chemistry. J. Chem. Educ. 2014, 91, 1895-1900. [CrossRef]

76. Josephson, P.; Nykvist, V.; Qasim, W.; Blomkvist, B.; DInér, P. Student-Driven Development of Greener Chemistry in Undergraduate Teaching: Synthesis of Lidocaine Revisited. J. Chem. Educ. 2019. [CrossRef]

77. Orwat, K.; Bernard, P.; Wróblewski, S.; Mendez, J.D. Traditional vs. Uv-Cured Coatings-An Inquiry-Based Experiment for Introducing Green Chemistry. Maced. J. Chem. Chem. Eng. 2018, 37, 215-224. [CrossRef]

78. Krenz, J.; Simcox, N.; Stoddard Tepe, J.; Simpson, C.D. Transitioning to Safer Chemicals in Academic Research Laboratories: Lessons Learned at the University of Washington. ACS Sustain. Chem. Eng. 2016, 4, 4021-4028. [CrossRef]

79. Lee, N.E.; Gurney, R.; Soltzberg, L. Using Green Chemistry Principles as a Framework to Incorporate Research into the Organic Laboratory Curriculum. J. Chem. Educ. 2014, 91, 1001-1008. [CrossRef]

80. Goode, S.R.; Wissinger, J.E.; Wood-Black, F. Introducing the Journal of Chemical Education's Special Issue on Chemical Safety Education: Methods, Culture, and Green Chemistry. J. Chem. Educ. 2021, 98, 1-6. [CrossRef]

81. Gómez-Biagi, R.F.; Dicks, A.P. Assessing Process Mass Intensity and Waste via an Aza-Baylis-Hillman Reaction. J. Chem. Educ. 2015, 92, 1938-1942. [CrossRef]

82. Fennie, M.W.; Roth, J.M. Comparing Amide-Forming Reactions Using Green Chemistry Metrics in an Undergraduate Organic Laboratory. J. Chem. Educ. 2016, 93, 1788-1793. [CrossRef]

83. Ribeiro, M.G.T.C.; Machado, A.S.C. Metal À Acetylacetonate Synthesis Experiments: Which Is Greener? J. Chem. Educ. 2011, 88, 947-953. [CrossRef]

84. Lam, C.H.; Escande, V.; Mellor, K.E.; Zimmerman, J.B.; Anastas, P.T. Teaching Atom Economy and E-Factor Concepts through a Green Laboratory Experiment: Aerobic Oxidative Cleavage of Meso-Hydrobenzoin to Benzaldehyde Using a Heterogeneous Catalyst. J. Chem. Educ. 2019, 96, 761-765. [CrossRef]

85. Tallmadge, W.; Homan, M.; Ruth, C.; Bilek, G. A Local Pollution Prevention Group Collaborates with a High School Intermediate Unit Bringing the Benefits of Microscale Chemistry to High School Chemistry Labs in the Lake Erie Watershed. Chem. Heal. Saf. 2004, 11, 30-33. [CrossRef] 
86. Zuin, V.G.; Segatto, M.L.; Zandonai, D.P.; Grosseli, G.M.; Stahl, A.; Zanotti, K.; Andrade, R.S. Integrating Green and Sustainable Chemistry into Undergraduate Teaching Laboratories: Closing and Assessing the Loop on the Basis of a Citrus Biorefinery Approach for the Biocircular Economy in Brazil. J. Chem. Educ. 2019, 96, 2975-2983. [CrossRef]

87. Hurst, G.A. Systems Thinking Approaches for International Green Chemistry Education. Curr. Opin. Green Sustain. Chem. 2020, 21, 93-97. [CrossRef]

88. Guron, M.; Paul, J.J.; Roeder, M.H. Incorporating Sustainability and Life Cycle Assessment into First-Year Inorganic Chemistry Major Laboratories. J. Chem. Educ. 2016, 93, 639-644. [CrossRef]

89. Gawlik-Kobylińska, M.; Walkowiak, W.; Maclejewski, P. Improvement of a Sustainable World through the Application of Innovative Didactic Tools in Green Chemistry Teaching: A Review. J. Chem. Educ. 2020, 97, 916-924. [CrossRef]

90. Grieger, K.; Leontyev, A. Promoting Student Awareness of Green Chemistry Principles via Student-Generated Presentation Videos. J. Chem. Educ. 2020, 97, 2657-2663. [CrossRef]

91. Laurillard, D. A Conversational Framework for the Effective Use of Learning Technologies, 1st ed.; Routledge: London, UK, 2002. [CrossRef]

92. Blatti, J.L.; Garcia, J.; Cave, D.; Monge, F.; Cuccinello, A.; Portillo, J.; Juarez, B.; Chan, E.; Schwebel, F. Systems Thinking in Science Education and Outreach toward a Sustainable Future. J. Chem. Educ. 2019, 96, 2852-2862. [CrossRef]

93. Dias, A.M.; Ferreira, M.L.S. "supermarket Column Chromatography of Leaf Pigments" Revisited: Simple and Ecofriendly Separation of Plant Carotenoids, Chlorophylls, and Flavonoids from Green and Red Leaves. J. Chem. Educ. 2015, 92, 189-192. [CrossRef]

94. Blatti, J.L. Colorful and Creative Chemistry: Making Simple Sustainable Paints with Natural Pigments and Binders. J. Chem. Educ. 2017, 94, 211-215. [CrossRef]

95. Karpudewan, M.; Ismail, Z.; Roth, W.M. Fostering Pre-Service Teachers' Self-Determined Environmental Motivation Through Green Chemistry Experiments. J. Sci. Teacher Educ. 2012, 23, 673-696. [CrossRef]

96. Karpudewan, M.; Ismail, Z.; Roth, W.M. Ensuring Sustainability of Tomorrow through Green Chemistry Integrated with Sustainable Development Concepts (SDCs). Chem. Educ. Res. Pract. 2012, 13, 120-127. [CrossRef]

97. Karpudewan, M.; Ismail, Z.; Roth, W.M. Promoting Pro-Environmental Attitudes and Reported Behaviors of Malaysian PreService Teachers Using Green Chemistry Experiments. Environ. Educ. Res. 2012, 18, 375-389. [CrossRef]

98. Teixeira, J.M.; Byers, J.N.; Perez, M.G.; Holman, R.W. The Question-Driven Laboratory Exercise: A New Pedagogy Applied to a Green Modification of Grignard Reagent Formation and Reaction. J. Chem. Educ. 2010, 87, 714-716. [CrossRef]

99. Karpudewan, M.; Kulandaisamy, Y. Malaysian Teachers' Insights into Implementing Green Chemistry Experiments in Secondary Schools. Curr. Opin. Green Sustain. Chem. 2018, 13, 113-117. [CrossRef]

100. Ribeiro, M.G.T.C.; MacHado, A.A.S.C. Holistic Metrics for Assessment of the Greenness of Chemical Reactions in the Context of Chemical Education. J. Chem. Educ. 2013, 90, 432-439. [CrossRef]

101. Garrecht, C.; Bruckermann, T.; Harms, U. Students' Decision-Making in Education for Sustainability-Related Extracurricular Activities-A Systematic Review of Empirical Studies. Sustainability 2018, 10, 3876. [CrossRef]

102. Abraham, L. A Green Nucleophilic Aromatic Substitution Reaction. J. Chem. Educ. 2020, 97, 3810-3815. [CrossRef]

103. Alberich, A.; Serrano, N.; Díaz-Cruz, J.M.; Ariño, C.; Esteban, M. Substitution of Mercury Electrodes by Bismuth-Coated Screen-Printed Electrodes in the Determination of Quinine in Tonic Water. J. Chem. Educ. 2013, 90, 1681-1684. [CrossRef]

104. Ali, Z.M.; Harris, V.H.; Lalonde, R.L. Beyond Green Chemistry: Teaching Social Justice in Organic Chemistry. J. Chem. Educ. 2020, 97, 3984-3991. [CrossRef]

105. Alwaseem, H.; Donahue, C.J.; Marincean, S. Catalytic Transfer Hydrogenation of Castor Oil. J. Chem. Educ. 2014, 91, 575-578. [CrossRef]

106. Amaris, Z.N.; Freitas, D.N.; Mac, K.; Gerner, K.T.; Nameth, C.; Wheeler, K.E. Nanoparticle Synthesis, Characterization, and Ecotoxicity: A Research-Based Set of Laboratory Experiments for a General Chemistry Course. J. Chem. Educ. 2017, 94, 1939-1945. [CrossRef]

107. Amin, S.; Barnes, A.; Buckner, C.; Jones, J.; Monroe, M.; Nurmomade, L.; Pinto, T.; Starkey, S.; Agee, B.M.; Crouse, D.J.; et al. Diels-Alder Reaction Using a Solar Irradiation Heat Source Designed for Undergraduate Organic Chemistry Laboratories. J. Chem. Educ. 2015, 92, 767-770. [CrossRef]

108. Armstrong, C.; Burnham, J.A.J.; Warminski, E.E. Combining Sustainable Synthesis of a Versatile Ruthenium Dihydride Complex with Structure Determination Using Group Theory and Spectroscopy. J. Chem. Educ. 2017, 94, 928-931. [CrossRef]

109. Arrebola, J.C.; Rodríguez-Fernández, N.; Caballero, Á. Decontamination of Wastewater Using Activated Biochar from Agricultural Waste: A Practical Experiment for Environmental Sciences Students. J. Chem. Educ. 2020, 97, 4137-4144. [CrossRef]

110. Aubrecht, K.B.; Padwa, L.; Shen, X.; Bazargan, G. Development and Implementation of a Series of Laboratory Field Trips for Advanced High School Students to Connect Chemistry to Sustainability. J. Chem. Educ. 2015, 92, 631-637. [CrossRef]

111. Bachofer, S.J.; Lingwood, M.D. A Green Determination of an Equilibrium Constant: Teaching New Skills. Phys. Sci. Rev. 2019, 3, 1-6. [CrossRef]

112. Bailey, A.; Andrews, L.; Khot, A.; Rubin, L.; Young, J.; Allston, T.D.; Takacs, G.A. Hydrogen Storage Experiments for an Undergraduate Laboratory Course-Clean Energy: Hydrogen/Fuel Cells. J. Chem. Educ. 2015, 92, 688-692. [CrossRef]

113. Ballard, C.E. Green Oxidative Homocoupling of 1-Methylimidazole. J. Chem. Educ. 2013, 90, 1368-1372. [CrossRef]

114. Ballard, C.E. Green Reductive Homocoupling of Bromobenzene. J. Chem. Educ. 2011, 88, 1148-1151. [CrossRef] 
115. Bannin, T.J.; Datta, P.P.; Kiesewetter, E.T.; Kiesewetter, M.K. Synthesizing Stilbene by Olefin Metathesis Reaction Using Guided Inquiry to Compare and Contrast Wittig and Metathesis Methodologies. J. Chem. Educ. 2019, 96, 143-147. [CrossRef]

116. Barcena, H.; Maziarz, K. Chemical Upcycling of Expired Drugs: Synthesis of Guaifenesin Acetonide. J. Chem. Educ. 2017, 94, 1538-1542. [CrossRef]

117. Barcena, H.; Tuachi, A.; Zhang, Y. Teaching Green Chemistry with Epoxidized Soybean Oil. J. Chem. Educ. 2017, 94, 1314-1318. [CrossRef]

118. Behnia, M.S.; Emerson, D.W.; Steinberg, S.M.; Alwis, R.M.; Duenas, J.A.; Serafino, J.O. A Simple, Safe Method for Preparation of Biodiesel. J. Chem. Educ. 2011, 88, 1290-1292. [CrossRef]

119. Bendall, S.; Birdsall-Wilson, M.; Jenkins, R.; Chew, Y.M.J.; Chuck, C.J. Showcasing Chemical Engineering Principles through the Production of Biodiesel from Spent Coffee Grounds. J. Chem. Educ. 2015, 92, 683-687. [CrossRef]

120. Bennett, G.D. A Green Polymerization of Aspartic Acid for the Undergraduate Organic Laboratory. J. Chem. Educ. 2005, 82, 1380-1381. [CrossRef]

121. Berger, M.; Karod, M.; Goldfarb, J.L. Invasive Species or Sustainable Water Filters? A Student-Led Laboratory Investigation into Locally Sourced Biomass-Based Adsorbents for Sustainable Water Treatment. Phys. Sci. Rev. 2019, 4, 1-15. [CrossRef]

122. Biswas, R.; Mukherjee, A. Introducing the Concept of Green Synthesis in the Undergraduate Laboratory: Two-Step Synthesis of 4-Bromoacetanilide from Aniline. J. Chem. Educ. 2017, 94, 1391-1394. [CrossRef]

123. Blatti, J.L.; Burkart, M.D. Releasing Stored Solar Energy within Pond Scum: Biodiesel from Algal Lipids. J. Chem. Educ. 2012, 89, 239-242. [CrossRef]

124. Bodsgard, B.R.; Lien, N.R.; Waulters, Q.T. Liquid $\mathrm{CO}_{2}$ Extraction and NMR Characterization of Anethole from Fennel Seed: A General Chemistry Laboratory. J. Chem. Educ. 2016, 93, 397-400. [CrossRef]

125. Cacciatore, K.L.; Amado, J.; Evans, J.J.; Sevian, H. Connecting Solubility, Equilibrium, and Periodicity in a Green, Inquiry Experiment for the General Chemistry Laboratory. J. Chem. Educ. 2008, 85, 251-253. [CrossRef]

126. Cacciatore, K.L.; Sevian, H. Teaching Lab Report Writing through Inquiry: A Green Chemistry Stoichiometry Experiment for General Chemistry. J. Chem. Educ. 2006, 83, 1039-1041. [CrossRef]

127. Cavalcante Dos Santos, R.; Cabral Cavalcanti, J.N.; Werneck Do Carmo, E.C.; De Souza, F.C.; Soares, W.G.; Gimenes De Souza, C.; França De Andrade, D.; D'Avila, L.A. Approaching Diesel Fuel Quality in Chemistry Lab Classes: Undergraduate Student's Achievements on Determination of Biodiesel Content in Diesel Oil Applying Solvatochromic Effect. J. Chem. Educ. 2020, 97, 4462-4468. [CrossRef]

128. Chan, J.M.W.; Zhang, X.; Brennan, M.K.; Sardon, H.; Engler, A.C.; Fox, C.H.; Frank, C.W.; Waymouth, R.M.; Hedrick, J.L. Organocatalytic Ring-Opening Polymerization of Trimethylene Carbonate to Yield a Biodegradable Polycarbonate. J. Chem. Educ. 2015, 92, 708-713. [CrossRef]

129. Chapman, S.; Herniman, J.M.; Langley, G.J.; Raja, R.; Logothetis, T.A. Redox Aluminophosphates: Applying Fundamental Undergraduate Theory to Solve Global Challenges in the Chemical Industry. J. Chem. Educ. 2019, 96, 2937-2946. [CrossRef]

130. Chemat, F.; Perino-Issartier, S.; Petitcolas, E.; Fernandez, X. "In Situ" Extraction of Essential Oils by Use of Dean-Stark Glassware and a Vigreux Column inside a Microwave Oven: A Procedure for Teaching Green Analytical Chemistry. Anal. Bioanal. Chem. 2012, 404, 679-682. [CrossRef] [PubMed]

131. Cheney, M.L.; Zaworotko, M.J.; Beaton, S.; Singer, R.D. Cocrystal Controlled Solid-State Synthesis. A Green Chemistry Experiment for Undergraduate Organic Chemistry. J. Chem. Educ. 2008, 85, 1649-1651. [CrossRef]

132. Cheung, L.L.W.; Styler, S.A.; Dicks, A.P. Rapid and Convenient Synthesis of the 1,4-Dihydropyridine Privileged Structure. J. Chem. Educ. 2010, 87, 628-630. [CrossRef]

133. Christensen, J.E.; Huddle, M.G.; Rogers, J.L.; Yung, H.; Mohan, R.S. The Discovery-Oriented Approach to Organic Chemistry. 7. Rearrangement of Trans-Stilbene Oxide with Bismuth Trifluoromethanesulfonate and Other Metal Triflates: A Microscale Green Organic Chemistry Laboratory Experiment. J. Chem. Educ. 2008, 85, 1274-1275. [CrossRef]

134. Clark, R.A.; Stock, A.E.; Zovinka, E.P. Metalloporphyrins as Oxidation Catalysts: Moving toward "Greener" Chemistry in the Inorganic Chemistry Laboratory. J. Chem. Educ. 2012, 89, 271-275. [CrossRef]

135. Colacino, E.; Dayaker, G.; Morère, A.; Friščić, T. Introducing Students to Mechanochemistry via Environmentally Friendly Organic Synthesis Using a Solvent-Free Mechanochemical Preparation of the Antidiabetic Drug Tolbutamide. J. Chem. Educ. 2019, 96, 766-771. [CrossRef]

136. Contreras-Cruz, D.A.; Cantú-Reyes, M.; García-Sánchez, J.M.; Peña-Ortíz, D.; Sánchez-Carmona, M.A.; Miranda, L.D. Shedding Blue Light on the Undergraduate Laboratory: An Easy-to-Assemble LED Photoreactor for Aromatization of a 1,4-Dihydropyridine. J. Chem. Educ. 2019. [CrossRef]

137. Cooper, P.D.; Walser, J. Total Chemical Footprint of an Experiment: A Systems Thinking Approach to Teaching Rovibrational Spectroscopy. J. Chem. Educ. 2019, 96, 2947-2951. [CrossRef]

138. Cosio, M.N.; Cardenal, A.D.; Maity, A.; Hyun, S.M.; Akwaowo, V.E.; Hoffman, C.W.; Powers, T.M.; Powers, D.C. Exploring Green Chemistry with Aerobic Hypervalent Iodine Catalysis. J. Chem. Educ. 2020, 97, 3816-3821. [CrossRef]

139. Costa, N.E.; Pelotte, A.L.; Simard, J.M.; Syvinski, C.A.; Deveau, A.M. Discovering Green, Aqueous Suzuki Coupling Reactions: Synthesis of Ethyl (4-Phenylphenyl)Acetate, a Biaryl with Anti-Arthritic Potential. J. Chem. Educ. 2012, 89, 1064-1067. [CrossRef]

140. Desmond, S.; Ray, C.; Andino Martínez, J.G. Educational Benefits of Green Chemistry. Phys. Sci. Rev. 2019, 2, 1-8. [CrossRef] 
141. Dhingra, S.; Angrish, C. Qualitative Organic Analysis: An Efficient, Safer, and Economical Approach to Preliminary Tests and Functional Group Analysis. J. Chem. Educ. 2011, 88, 649-651. [CrossRef]

142. Dicks, A.P.; D'Eon, J.C.; Morra, B.; Kutas Chisu, C.; Quinlan, K.B.; Cannon, A.S. A Systems Thinking Department: Fostering a Culture of Green Chemistry Practice among Students. J. Chem. Educ. 2019, 96, 2836-2844. [CrossRef]

143. Dintzner, M.R.; Kinzie, C.R.; Pulkrabek, K.; Arena, A.F. The Cyclohexanol Cycle and Synthesis of Nylon 6,6: Green Chemistry in the Undergraduate Organic Laboratory. J. Chem. Educ. 2012, 89, 262-264. [CrossRef]

144. Dintzner, M.R.; Maresh, J.J.; Kinzie, C.R.; Arena, A.F.; Speltz, T. A Research-Based Undergraduate Organic Laboratory Project: Investigation of a One-Pot, Multicomponent, Environmentally Friendly Prins-Friedel-Crafts-Type Reaction. J. Chem. Educ. 2012, 89, 265-267. [CrossRef]

145. Divya, D.; Raj, K.G. From Scrap to Functional Materials: Exploring Green and Sustainable Chemistry Approach in the Undergraduate Laboratory. J. Chem. Educ. 2019, 96, 535-539. [CrossRef]

146. Dorney, K.M.; Baker, J.D.; Edwards, M.L.; Kanel, S.R.; O’Malley, M.; Sizemore, I.E.P. Tangential Flow Filtration of Colloidal Silver Nanoparticles: A “Green” Laboratory Experiment for Chemistry and Engineering Students. J. Chem. Educ. 2014, 91, 1044-1049. [CrossRef]

147. Dos Santos, R.V.; Viana, G.M.; Moreira, A.F.S.; Nóbrega, V.S.; da Silva, V.A.S.; Malta, L.F.B.; Aguiar, L.C.S.; Senra, J.D. Revisiting the Nucleophilicity Concept in a Comprehensive Biomass Valorization Experiment: From Papaya Seeds to Thiourea Motifs. Quim. Nova 2019, 42, 940-946. [CrossRef]

148. Edgar, L.J.G.; Koroluk, K.J.; Golmakani, M.; Dicks, A.P. Green Chemistry Decision-Making in an Upper-Level Undergraduate Organic Laboratory. J. Chem. Educ. 2014, 91, 1040-1043. [CrossRef]

149. Eissen, M. Sustainable Production of Chemicals-an Educational Perspective. Chem. Educ. Res. Pract. 2012, 13, 103-111. [CrossRef]

150. Félix, S.; Araújo, J.; Pires, A.M.; Sousa, A.C. Soap Production: A Green Prospective. Waste Manag. 2017, 66, 190-195. [CrossRef] [PubMed]

151. Förster, C.; Heinze, K. Preparation and Thermochromic Switching between Phosphorescence and Thermally Activated Delayed Fluorescence of Mononuclear Copper(I) Complexes. J. Chem. Educ. 2020, 97, 1644-1649. [CrossRef]

152. Geiger, H.C.; Donohoe, J.S. Green Oxidation of Menthol Enantiomers and Analysis by Circular Dichroism Spectroscopy: An Advanced Organic Chemistry Laboratory. J. Chem. Educ. 2012, 89, 1572-1574. [CrossRef]

153. Go, E.B.; Srisuknimit, V.; Cheng, S.L.; Vosburg, D.A. Self-Assembly, Guest Capture, and NMR Spectroscopy of a Metal-Organic Cage in Water. J. Chem. Educ. 2016, 93, 368-371. [CrossRef]

154. Goodwin, T.E. An Asymptotic Approach to the Development of a Green Organic Chemistry Laboratory. J. Chem. Educ. 2004, 81, 1187-1190. [CrossRef]

155. Günter, T.; Akkuzu, N.; Alpat, Ş. Understanding 'Green Chemistry' and 'Sustainability': An Example of Problem-Based Learning (PBL). Res. Sci. Technol. Educ. 2017, 35, 500-520. [CrossRef]

156. Hamilton, A.E.; Buxton, A.M.; Peeples, C.J.; Chalker, J.M. An Operationally Simple Aqueous Suzuki-Miyaura Cross-Coupling Reaction for an Undergraduate Organic Chemistry Laboratory. J. Chem. Educ. 2013, 90, 1509-1513. [CrossRef]

157. Hie, L.; Chang, J.J.; Garg, N.K. Nickel-Catalyzed Suzuki-Miyaura Cross-Coupling in a Green Alcohol Solvent for an Undergraduate Organic Chemistry Laboratory. J. Chem. Educ. 2015, 92, 571-574. [CrossRef]

158. Hill, N.J.; Bowman, M.D.; Esselman, B.J.; Byron, S.D.; Kreitinger, J.; Leadbeater, N.E. Ligand-Free Suzuki-Miyaura Coupling Reactions Using an Inexpensive Aqueous Palladium Source: A Synthetic and Computational Exercise for the Undergraduate Organic Chemistry Laboratory. J. Chem. Educ. 2014, 91, 1054-1057. [CrossRef]

159. Hill, N.J.; Hoover, J.M.; Stahl, S.S. Aerobic Alcohol Oxidation Using a Copper(I)/TEMPO Catalyst System: A Green, Catalytic Oxidation Reaction for the Undergraduate Organic Chemistry Laboratory. J. Chem. Educ. 2013, 90, 102-105. [CrossRef]

160. Hoang, G.T.; Kubo, T.; Young, V.G.; Kautzky, J.A.; Wissinger, J.E. Illustrating the Utility of X-ray Crystallography for Structure Elucidation through a Tandem Aldol Condensation/Diels-Alder Reaction Sequence. J. Chem. Educ. 2015, 92, 1381-1384. [CrossRef]

161. Hopson, R.; Lee, P.Y.B.; Hess, K.M. 1-Dimensional Selective Nuclear Overhauser Effect NMR Spectroscopy to Characterize Products from a Two-Step Green Chemistry Synthesis. J. Chem. Educ. 2018, 95, 641-647. [CrossRef]

162. Horta, J.E. Simple Microwave-Assisted Claisen and Dieckmann Condensation Experiments for the Undergraduate Organic Chemistry Laboratory. J. Chem. Educ. 2011, 88, 1014-1015. [CrossRef]

163. Hurst, G.A. Green and Smart: Hydrogels to Facilitate Independent Practical Learning. J. Chem. Educ. 2017, 94, 1766-1771. [CrossRef]

164. Hwang, H.L.; Jadhav, S.R.; Silverman, J.R.; John, G. Sweet and Sustainable: Teaching the Biorefinery Concept through Biobased Gelator Synthesis. J. Chem. Educ. 2014, 91, 1563-1568. [CrossRef]

165. Ison, E.A.; Ison, A. Synthesis of Well-Defined Copper N-Heterocyclic Carbene Complexes and Their Use as Catalysts for a “Click Reaction": A Multistep Experiment That Emphasizes the Role of Catalysis in Green Chemistry. J. Chem. Educ. 2012, 4, 1575-1577. [CrossRef]

166. Johnston, A.; Scaggs, J.; Mallory, C.; Haskett, A.; Warner, D.; Brown, E.; Hammond, K.; McCormick, M.M.; McDougal, O.M. A Green Approach to Separate Spinach Pigments by Column Chromatography. J. Chem. Educ. 2013, 90, 796-798. [CrossRef]

167. Jones-Wilson, T.M.; Burtch, E.A. A Green Starting Material for Electrophilic Aromatic Substitution for the Undergraduate Organic Laboratory. J. Chem. Educ. 2005, 82, 616-617. [CrossRef] 
168. Karpudewan, M.; Mathanasegaran, K. Exploring the Use of Context-Based Green Chemistry Experiments in Understanding the Effects of Concentration and Catalyst on the Rate of Reaction. Asia-Pac. Forum Sci. Learn. Teach. 2018, 19, 3.

169. Karpudewan, M.; Roth, W.M.; Ismail, Z. The Effects of “Green Chemistry" on Secondary School Students' Understanding and Motivation. Asia-Pac. Educ. Res. 2015, 24, 35-43. [CrossRef]

170. Keen, C.; Couture, S.; Abd El Meseh, N.; Sevian, H. Connecting Theory to Life: Learning Greener Electrochemistry by Taking Apart a Common Battery. J. Chem. Educ. 2020, 97, 934-942. [CrossRef]

171. Kelly, M.J.B.; Fallot, L.B.; Gustafson, J.L.; Bergdahl, B.M. Water Mediated Wittig Reactions of Aldehydes in the Teaching Laboratory: Using Sodium Bicarbonate for the in Situ Formation of Stabilized Ylides. J. Chem. Educ. 2016, 93, 1631-1636. [CrossRef]

172. Khuong, K.S. Greener Oxidation of Benzhydrol: Evaluating Three Oxidation Procedures in the Organic Laboratory. J. Chem. Educ. 2017, 94, 534-537. [CrossRef]

173. Klingshirn, M.A.; Wyatt, A.F.; Hanson, R.M.; Spessard, G.O. Determination of the Formula of a Hydrate: A Greener Alternative. J. Chem. Educ. 2008, 85, 819-821. [CrossRef]

174. Klotz, E.; Doyle, R.; Gross, E.; Mattson, B. The Equilibrium Constant for Bromothymol Blue: A General Chemistry Laboratory Experiment Using Spectroscopy. J. Chem. Educ. 2011, 88, 637-639. [CrossRef]

175. Knutson, C.M.; Hilker, A.P.; Tolstyka, Z.P.; Anderson, C.B.; Wilbon, P.A.; Mathers, R.T.; Wentzel, M.T.; Perkins, A.L.; Wissinger, J.E. Dyeing to Degrade: A Bioplastics Experiment for College and High School Classrooms. J. Chem. Educ. 2019, 96, 2565-2573. [CrossRef]

176. Knutson, C.M.; Schneiderman, D.K.; Yu, M.; Javner, C.H.; Distefano, M.D.; Wissinger, J.E. Polymeric Medical Sutures: An Exploration of Polymers and Green Chemistry. J. Chem. Educ. 2017, 94, 1761-1765. [CrossRef]

177. Koch, A.S.; Chimento, C.A.; Berg, A.N.; Mughal, F.D.; Spencer, J.P.; Hovland, D.E.; Mbadugha, B.; Hovland, A.K.; Eller, L.R. Extraction of Maltol from Fraser Fir: A Comparison of Microwave-Assisted Extraction and Conventional Heating Protocols for the Organic Chemistry Laboratory. J. Chem. Educ. 2015, 92, 170-174. [CrossRef]

178. Koroluk, K.J.; Jackson, D.A.; Dicks, A.P. The Petasis Reaction: Microscale Synthesis of a Tertiary Amine Antifungal Analog. J. Chem. Educ. 2012, 89, 796-798. [CrossRef]

179. Kradtap Hartwell, S. Exploring the Potential for Using Inexpensive Natural Reagents Extracted from Plants to Teach Chemical Analysis. Chem. Educ. Res. Pract. 2012, 13, 135-146. [CrossRef]

180. Kurowska-Susdorf, A.; Zwierżdżyński, M.; Bevanda, A.M.; Talić, S.; Ivanković, A.; Płotka-Wasylka, J. Green Analytical Chemistry: Social Dimension and Teaching. TrAC-Trends Anal. Chem. 2019, 111, 185-196. [CrossRef]

181. Lam, C.H.; Jackson, J.E. Teaching Electrochemistry with Common Objects: Electrocatalytic Hydrogenation of Acetol with U.S. Coins. J. Chem. Educ. 2020, 97, 172-177. [CrossRef]

182. Landstrom, E.B.; Nichol, M.; Lipshutz, B.H.; Gainer, M.J. Discovery-Based SNAr Experiment in Water Using Micellar Catalysis. J. Chem. Educ. 2019, 96, 2668-2671. [CrossRef]

183. Lang, P.T.; Harned, A.M.; Wissinger, J.E. Oxidation of Borneol to Camphor Using Oxone and Catalytic Sodium Chloride: A Green Experiment for the Undergraduate Organic Chemistry Laboratory. J. Chem. Educ. 2011, 88, 652-656. [CrossRef]

184. Lapanantnoppakhun, S.; Tengjaroensakul, U.; Mungkornasawakul, P.; Puangpila, C.; Kittiwachana, S.; Saengtempiam, J.; Hartwell, S.K. Green Analytical Chemistry Experiment: Quantitative Analysis of Iron in Supplement Tablets with Vis Spectrophotometry Using Tea Extract as a Chromogenic Agent. J. Chem. Educ. 2020, 97, 207-214. [CrossRef]

185. Lasker, G.A.; Simcox, N.J.; Mellor, K.E.; Mullins, M.L.; Nesmith, S.M.; Van Bergen, S.; Anastas, P.T. Introducing Toxicology into the Undergraduate Chemistry Laboratory Using Safety Data Sheets and Sunscreen Activities. J. Chem. Educ. 2019, 96, 720-724. [CrossRef]

186. Leslie, J.M.; Tzeel, B.A. Gold(III)-Catalyzed Hydration of Phenylacetylene. J. Chem. Educ. 2016, 93, 1100-1102. [CrossRef]

187. Leslie, R.; Leeb, E.; Smith, R.B. Synthesis of Ethyl Nalidixate: A Medicinal Chemistry Experiment. J. Chem. Educ. 2012, 89, 144-146. [CrossRef]

188. Leung, S.H.; Angel, S.A. Solvent-Free Wittig Reaction: A Green Organic Chemistry Laboratory Experiment. J. Chem. Educ. 2004, 81, 1492-1493. [CrossRef]

189. Lin, Y.; Zhao, H.; Yu, F.; Yang, J. Design of an Extended Experiment with Electrical Double Layer Capacitors: Electrochemical Energy Storage Devices in Green Chemistry. Sustainability 2018, 10, 3630. [CrossRef]

190. Lipshutz, B.H.; Bošković, Z.; Crowe, C.S.; Davis, V.K.; Whittemore, H.C.; Vosburg, D.A.; Wenzel, A.G. “Click” and Olefin Metathesis Chemistry in Water at Room Temperature Enabled by Biodegradable Micelles. J. Chem. Educ. 2013, 90, 1514-1517. [CrossRef] [PubMed]

191. Liu, Y.; Myers, E.J.; Rydahl, S.A.; Wang, X. Ultrasonic-Assisted Synthesis, Characterization, and Application of a Metal-Organic Framework: A Green General Chemistry Laboratory Project. J. Chem. Educ. 2019, 96, 2286-2291. [CrossRef]

192. Lu, G.P.; Chen, F.; Cai, C. Thiourea in the Construction of C-S Bonds as Part of an Undergraduate Organic Chemistry Laboratory Course. J. Chem. Educ. 2017, 94, 244-247. [CrossRef]

193. Mackenzie, L.S.; Tyrrell, H.; Thomas, R.; Matharu, A.S.; Clark, J.H.; Hurst, G.A. Valorization of Waste Orange Peel to Produce Shear-Thinning Gels. J. Chem. Educ. 2019, 96, 3025-3029. [CrossRef]

194. Manchanayakage, R. Designing and Incorporating Green Chemistry Courses at a Liberal Arts College to Increase Students' Awareness and Interdisciplinary Collaborative Work. J. Chem. Educ. 2013, 90, 1167-1171. [CrossRef] 
195. Marcos, C.F.; Neo, A.G.; Díaz, J.; Martínez-Caballero, S. A Safe and Green Benzylic Radical Bromination Experiment. J. Chem. Educ. 2020, 97, 582-585. [CrossRef]

196. Martin, E.; Kellen-Yuen, C. Microwave-Assisted Organic Synthesis in the Organic Lab: A Simple, Greener Wittig Reaction. J. Chem. Educ. 2007, 84, 2004-2006. [CrossRef]

197. McAllister, G.D.; Parsons, A.F. Going Green in Process Chemistry: Optimizing an Asymmetric Oxidation Reaction to Synthesize the Antiulcer Drug Esomeprazole. J. Chem. Educ. 2019, 96, 2617-2621. [CrossRef]

198. McKee, J.R.; Zanger, M.; Chiariello, C.; McKee, J.A.; Dorfner, W.; Fasella, E.; Koo, Y. Semimicro/Microscale Adaptation of the Cobalt Chloride/Sodium Borohydride Reduction of Methyl Oleate. J. Chem. Educ. 2019, 96, 772-775. [CrossRef]

199. McKenzie, L.C.; Huffman, L.M.; Parent, K.E.; Hutchison, J.E.; Thompson, J.E. Patterning Self-Assembled Monolayers on Gold: Green Materials Chemistry in the Teaching Laboratory. J. Chem. Educ. 2004, 81, 545-548. [CrossRef]

200. Mio, M.J. How the Principles of Green Chemistry Changed the Way Organic Chemistry Labs Are Taught at the University of Detroit Mercy. Phys. Sci. Rev. 2017, 2, 1-5. [CrossRef]

201. Mohan, R.S.; Mejia, M.P. Environmentally Friendly Organic Chemistry Laboratory Experiments for the Undergraduate Curriculum: A Literature Survey and Assessment. J. Chem. Educ. 2020, 97, 943-959. [CrossRef]

202. Mooney, D. Effectively Minimizing Hazardous Waste in Academia: The Green Chemistry Approach. Chem. Heal. Saf. 2004, 11, 24-28. [CrossRef]

203. Mooney, M.; Vreugdenhil, A.J.; Shetranjiwalla, S. A Toolkit of Green Chemistry and Life-Cycle Analysis for Comparative Assessment in Undergraduate Organic Chemistry Experiments: Synthesis of (E)-Stilbene. J. Chem. Educ. 2020, 97, 1336-1344. [CrossRef]

204. Morris, R.K.; Hilker, A.P.; Mattice, T.M.; Donovan, S.M.; Wentzel, M.T.; Willoughby, P.H. Simple and Versatile Protocol for Preparing Self-Healing Poly(Vinyl Alcohol) Hydrogels. J. Chem. Educ. 2019, 96, 2247-2252. [CrossRef]

205. Morsch, L.A.; Deak, L.; Tiburzi, D.; Schuster, H.; Meyer, B. Green Aqueous Wittig Reaction: Teaching Green Chemistry in Organic Teaching Laboratories. J. Chem. Educ. 2014, 91, 611-614. [CrossRef]

206. Mullins, J.J.; Prusinowski, A.F. Microwave-Promoted Synthesis of a Carbocyclic Curcuminoid: An Organic Chemistry Laboratory Experiment. J. Chem. Educ. 2019, 96, 606-609. [CrossRef]

207. Murphy, K.C.; Dilip, M.; Quattrucci, J.G.; Mitroka, S.M.; Andreatta, J.R. Sustainable Consumer Choices: An Outreach Program Exploring the Environmental Impact of Our Consumer Choices Using a Systems Thinking Model and Laboratory Activities. J. Chem. Educ. 2019, 96, 2993-2999. [CrossRef]

208. Nigam, M.; Rush, B.; Patel, J.; Castillo, R.; Dhar, P. Aza-Michael Reaction for an Undergraduate Organic Chemistry Laboratory. J. Chem. Educ. 2016, 93, 753-756. [CrossRef]

209. Obhi, N.K.; Mallov, I.; Borduas-Dedekind, N.; Rousseaux, S.A.L.; Dicks, A.P. Comparing Industrial Amination Reactions in a Combined Class and Laboratory Green Chemistry Assignment. J. Chem. Educ. 2019, 96, 93-99. [CrossRef]

210. Paluri, S.L.A.; Edwards, M.L.; Lam, N.H.; Williams, E.M.; Meyerhoefer, A.; Sizemore, I.E.P. Introducing Green and Nongreen Aspects of Noble Metal Nanoparticle Synthesis: An Inquiry-Based Laboratory Experiment for Chemistry and Engineering Students. J. Chem. Educ. 2015, 92, 350-354. [CrossRef]

211. Panda, D.; Patra, S.; Awasthi, M.K.; Singh, S.K. Lab Cooked MOF for $\mathrm{CO}_{2}$ Capture: A Sustainable Solution to Waste Management. ACS Appl. Mater. Interfaces 2020, 97, 1101-1108. [CrossRef]

212. Pandarus, V.; Ciriminna, R.; Béland, F.; Pagliaro, M. Making Fine Chemicals, Nanomaterials and Pharmaceutical Ingredients over SiliaCat Catalysts. Appl. Mater. Today 2020, 20, 100661. [CrossRef]

213. Panzarasa, G. Just Add Luminol to Turn the Spotlight on Radziszewski Amidation. ACS Omega 2018, 3, 13179-13182. [CrossRef]

214. Panzarasa, G.; Sparnacci, K. Glowing Teacup Demonstration: Trautz-Schorigin Reaction of Natural Polyphenols. J. Chem. Educ. 2012, 89, 1297-1300. [CrossRef]

215. Patterson, A.L.; May, M.D.; Visser, B.J.; Kislukhin, A.A.; Vosburg, D.A. Solvent-Free Synthesis and Fluorescence of a Thiol-Reactive Sensor for Undergraduate Organic Laboratories. J. Chem. Educ. 2013, 90, 1685-1687. [CrossRef]

216. Peng, H.C.; Bryan, J.; Henson, W.; Zhdankin, V.V.; Gandhi, K.; David, S. New, Milder Hypervalent Iodine Oxidizing Agent: Using $\mu$-Oxodi(Phenyliodanyl) Diacetate, a (Diacetoxyiodo)Benzene Derivative, in the Synthesis of Quinones. J. Chem. Educ. 2019, 96, 2622-2627. [CrossRef]

217. Pereira, T.M.; Franco, D.F.P.; Vitório, F.; Amaral, R.C.; Ponzoni, A.C.; Kümmerle, A. Microwave-Assisted Synthesis and Pka Determination of Umbelliferone: An Experiment for the Undergraduate Organic Chemistry Laboratory. Quim. Nova 2018, 41, 1205-1208. [CrossRef]

218. Pfab, E.; Filiciotto, L.; Luque, R. The Dark Side of Biomass Valorization: A Laboratory Experiment to Understand Humin Formation, Catalysis, and Green Chemistry. J. Chem. Educ. 2019, 96, 3030-3037. [CrossRef]

219. Pohl, N.L.B.; Streff, J.M.; Brokman, S. Evaluating Sustainability: Soap vs. Biodiesel Production from Plant Oils. J. Chem. Educ. 2012, 89, 1053-1056. [CrossRef]

220. Priest, M.A.; Padgett, L.W.; Padgett, C.W. Demonstrating the Temperature Dependence of Density via Construction of a Galilean Thermometer. J. Chem. Educ. 2011, 88, 983-985. [CrossRef]

221. Purcell, S.C.; Pande, P.; Lin, Y.; Rivera, E.J.; Latisha, P.U.; Smallwood, L.M.; Kerstiens, G.A.; Armstrong, L.B.; Robak, M.T.; Baranger, A.M.; et al. Extraction and Antibacterial Properties of Thyme Leaf Extracts: Authentic Practice of Green Chemistry. J. Chem. Educ. 2016, 93, 1422-1427. [CrossRef] 
222. Raghuwanshi, V.S.; Wendt, R.; O’Neill, M.; Ochmann, M.; Som, T.; Fenger, R.; Mohrmann, M.; Hoell, A.; Rademann, K. Bringing Catalysis with Gold Nanoparticles in Green Solvents to Graduate Level Students. J. Chem. Educ. 2017, 94, 510-514. [CrossRef]

223. Rajapaksha, S.M.; Samarasekara, D.; Brown, J.C.; Howard, L.; Gerken, K.; Archer, T.; Lathan, P.; Mlsna, T.; Mlsna, D. Determination of Xylitol in Sugar-Free Gum by GC-MS with Direct Aqueous Injection: A Laboratory Experiment for Chemistry Students. J. Chem. Educ. 2018, 95, 2017-2022. [CrossRef]

224. Rajchakit, U.; Limpanuparb, T. Greening the Traffic Light: Air Oxidation of Vitamin C Catalyzed by Indicators. J. Chem. Educ. 2016, 93, 1486-1489. [CrossRef]

225. Rattanakit, P.; Maungchang, R. Determining Iron(III) Concentration in a Green Chemistry Experiment Using Phyllanthus emblica (Indian Gooseberry) Extract and Spectrophotometry. J. Chem. Educ. 2019, 96, 756-760. [CrossRef]

226. Reilly, M.K.; King, R.P.; Wagner, A.J.; King, S.M. Microwave-Assisted Esterification: A Discovery-Based Microscale Laboratory Experiment. J. Chem. Educ. 2014, 91, 1706-1709. [CrossRef]

227. Ribeiro, M.G.T.C.; Machado, A.A.S.C. Greenness of Chemical Reactions-Limitations of Mass Metrics. Green Chem. Lett. Rev. 2013, 6, 1-18. [CrossRef]

228. Rosatella, A.A.; Afonso, C.A.M.; Branco, L.C. Oxidation of Cyclohexene to Trans-1,2-Cyclohexanediol Promoted by p-Toluenesulfonic Acid without Organic Solvents. J. Chem. Educ. 2011, 88, 1002-1003. [CrossRef]

229. Rubner, I.; Berry, A.J.; Grofe, T.; Oetken, M. Educational Modules on the Power-to-Gas Concept Demonstrate a Path to Renewable Energy Futures. J. Chem. Educ. 2019, 96, 248-255. [CrossRef]

230. Salman Ashraf, S.; Rauf, M.A.; Abdullah, F.H. A Hands-on Approach to Teaching Environmental Awareness and Pollutant Remediation to Undergraduate Chemistry Students. Res. Sci. Technol. Educ. 2012, 30, 173-184. [CrossRef]

231. Samet, C.; Valiyaveettil, S. Fruit and Vegetable Peels as Efficient Renewable Adsorbents for Removal of Pollutants from Water: A Research Experience for General Chemistry Students. J. Chem. Educ. 2018, 95, 1354-1358. [CrossRef]

232. Sampaio, C.I.; Sousa, L.F.; Dias, A.M. Separation of Anthocyaninic and Nonanthocyaninic Flavonoids by Liquid-Liquid Extraction Based on Their Acid-Base Properties: A Green Chemistry Approach. J. Chem. Educ. 2020, 97, 4533-4539. [CrossRef]

233. Santandrea, J.; Kairouz, V.; Collins, S.K. Continuous Flow Science in an Undergraduate Teaching Laboratory: Photocatalytic Thiol-Ene Reaction Using Visible Light. J. Chem. Educ. 2018, 95, 1073-1077. [CrossRef]

234. Schaber, P.M.; Larkin, J.E.; Pines, H.A.; Berchou, K.; Wierchowski, E.; Marconi, A.; Suriani, A. Supercritical Fluid Extraction versus Traditional Solvent Extraction of Caffeine from Tea Leaves: A Laboratory-Based Case Study for an Organic Chemistry Course. J. Chem. Educ. 2012, 89, 1327-1330. [CrossRef]

235. Schneiderman, D.K.; Gilmer, C.; Wentzel, M.T.; Martello, M.T.; Kubo, T.; Wissinger, J.E. Sustainable Polymers in the Organic Chemistry Laboratory: Synthesis and Characterization of a Renewable Polymer from $\delta$-Decalactone and L-Lactide. J. Chem. Educ. 2014, 91, 131-135. [CrossRef]

236. Serafin, M.; Priest, O.P. Identifying Passerini Products Using a Green, Guided-Inquiry, Collaborative Approach Combined with Spectroscopic Lab Techniques. J. Chem. Educ. 2015, 92, 579-581. [CrossRef]

237. Sharma, R.K.; Yadav, S.; Gupta, R.; Arora, G. Synthesis of Magnetic Nanoparticles Using Potato Extract for Dye Degradation: A Green Chemistry Experiment. J. Chem. Educ. 2019, 96, 3038-3044. [CrossRef]

238. Sharma, R.K.; Sharma, C.; Sidhwani, I.T. Solventless and One-Pot Synthesis of Cu(II) Phthalocyanine Complex: A Green Chemistry Experiment. J. Chem. Educ. 2011, 88, 86-87. [CrossRef]

239. Shell, T.A.; Shell, J.R.; Poole, K.A.; Guetzlo, T.F. Microwave-Assisted Synthesis of N-Phenylsuccinimide. J. Chem. Educ. 2011, 88, 1439-1441. [CrossRef] [PubMed]

240. Shimizu, E.A.; Cory, B.; Hoang, J.; Castro, G.G.; Jung, M.E.; Vosburg, D.A. Aqueous Dearomatization/Diels-Alder Cascade to a Grandifloracin Precursor. J. Chem. Educ. 2019, 96, 998-1001. [CrossRef]

241. Silveira, G.; Ikegaki, M.; Schneedorf, J.M. A Low-Cost Yeast-Based Biofuel Cell: An Educational Green Approach. Green Chem. Lett. Rev. 2017, 10, 32-41. [CrossRef]

242. Silverman, J.R. Biobased Organic Chemistry Laboratories as Sustainable Experiment Alternatives. J. Chem. Educ. 2016, 93, 1679-1681. [CrossRef]

243. Simeonov, S.P.; Afonso, C.A.M. Batch and Flow Synthesis of 5-Hydroxymethylfurfural (HMF) from Fructose as a Bioplatform Intermediate: An Experiment for the Organic or Analytical Laboratory. J. Chem. Educ. 2013, 90, 1373-1375. [CrossRef]

244. Sims, P.A.; Branscum, K.M.; Kao, L.; Keaveny, V.R. An Inexpensive, Relatively Green, and Rapid Method to Purify Genomic DNA from Escherichia coli: An Experiment for the Undergraduate Biochemistry Laboratory. J. Chem. Educ. 2010, 87, 1113-1115. [CrossRef]

245. Smith, M.K.; Angle, S.R.; Northrop, B.H. Preparation and Analysis of Cyclodextrin-Based Metal-Organic Frameworks: Laboratory Experiments Adaptable for High School through Advanced Undergraduate Students. J. Chem. Educ. 2015, 92, 368-372. [CrossRef]

246. Soares, P.; Fernandes, C.; Chavarria, D.; Borges, F. Microwave-Assisted Synthesis of 5-Phenyl-2-Hydroxyacetophenone Derivatives by a Green Suzuki Coupling Reaction. J. Chem. Educ. 2015, 92, 575-578. [CrossRef]

247. Sobral, A.J.F.N. Synthesis of Meso-Diethyl-2,2'-Dipyrromethane in Water. J. Chem. Educ. 2006, 83, 1665-1666. [CrossRef]

248. Solomon, S.D.; Rutkowsky, S.A.; Mahon, M.L.; Halpern, E.M. Synthesis of Copper Pigments, Malachite and Verdigris: Making Tempera Paint. J. Chem. Educ. 2011, 88, 1694-1697. [CrossRef]

249. Stacey, J.M.; Dicks, A.P.; Goodwin, A.A.; Rush, B.M.; Nigam, M. Green Carbonyl Condensation Reactions Demonstrating Solvent and Organocatalyst Recyclability. J. Chem. Educ. 2013, 90, 1067-1070. [CrossRef] 
250. Steele, J.H.; Bozor, M.X.; Boyce, G.R. Transmutation of Scent: An Evaluation of the Synthesis of Methyl Cinnamate, a Commercial Fragrance, via a Fischer Esterification for the Second-Year Organic Laboratory. J. Chem. Educ. 2020, 97, 4127-4132. [CrossRef]

251. Strachan, J.; Barnett, C.; Maschmeyer, T.; Masters, A.F.; Motion, A.; Yuen, A.K.L. Nanoparticles for Undergraduates: Creation, Characterization, and Catalysis. J. Chem. Educ. 2020, 97, 4166-4172. [CrossRef]

252. Sues, P.E.; Cai, K.; McIntosh, D.F.; Morris, R.H. Template Effect and Ligand Substitution Methods for the Synthesis of Iron Catalysts: A Two-Part Experiment for Inorganic Chemistry. J. Chem. Educ. 2015, 92, 378-381. [CrossRef]

253. Sutheimer, S.; Caster, J.M.; Smith, S.H. Green Soap: An Extraction and Saponification of Avocado Oil. J. Chem. Educ. 2015, 92, 1763-1765. [CrossRef]

254. Tian, J.; Yan, L.; Sang, A.; Yuan, H.; Zheng, B.; Xiao, D. Microwave-Assisted Synthesis of Red-Light Emitting Au Nanoclusters with the Use of Egg White. J. Chem. Educ. 2014, 91, 1715-1719. [CrossRef]

255. Timmer, B.J.J.; Schaufelberger, F.; Hammarberg, D.; Franzén, J.; Ramström, O.; Dinér, P. Simple and Effective Integration of Green Chemistry and Sustainability Education into an Existing Organic Chemistry Course. J. Chem. Educ. 2018, 95, 1301-1306. [CrossRef]

256. Touaibia, M.; Selka, A.; Levesque, N.A.; St-Onge, P.A. Green Hydrogenation: Solvent-Free Hydrogenation of Pinenes for an Undergraduate Organic Chemistry Laboratory. J. Chem. Educ. 2020, 97, 2296-2301. [CrossRef]

257. Vargas, B.P.; Rosa, C.H.; Rosa, D.D.S.; Rosa, G.R. “Green” Suzuki-Miyaura Cross-Coupling: An Exciting Mini-Project for Chemistry Undergraduate Students. Educ. Quim. 2016, 27, 139-142. [CrossRef]

258. Verdía, P.; Santamarta, F.; Tojo, E. Synthesis of (3-Methoxycarbonyl)Coumarin in an Ionic Liquid: An Advanced Undergraduate Project for Green Chemistry. J. Chem. Educ. 2017, 94, 505-509. [CrossRef]

259. Villalba, M.M.; Leslie, R.; Davis, J.; Smith, R. Designer Experiments to Assist in the Teaching of NMR Spectroscopy. A Spectroscopic Experiment in Green Chemistry. J. Sci. Educ. 2011, 12, 38-40.

260. Virot, M.; Tomao, V.; Ginies, C.; Chemat, F. Total Lipid Extraction of Food Using D-Limonene as an Alternative to $n$-Hexane. Chromatographia 2008, 68, 311-313. [CrossRef]

261. Vogelzang, J.; Admiraal, W.F.; Van Driel, J.H. Effects of Scrum Methodology on Students' Critical Scientific Literacy: The Case of Green Chemistry. Chem. Educ. Res. Pract. 2020, 21, 940-952. [CrossRef]

262. Von Dollen, J.; Oliva, S.; Max, S.; Esbenshade, J. Recovery of Silver Nitrate from Silver Chloride Waste. J. Chem. Educ. 2018, 95, 682-685. [CrossRef]

263. Wagner, E.P.; Koehle, M.A.; Moyle, T.M.; Lambert, P.D. How Green Is Your Fuel? Creation and Comparison of Automotive Biofuels. Synthesis 2010, 87, 711-713. [CrossRef]

264. Wang, X.; Chrzanowski, M.; Liu, Y. Ultrasonic-Assisted Transesterification: A Green Miniscale Organic Laboratory Experiment. J. Chem. Educ. 2020, 97, 1123-1127. [CrossRef]

265. Wang, Y.; Zhang, M.; Hu, Y. Foam Fractionation of Lycopene: An Undergraduate Chemistry Experiment. J. Chem. Educ. 2010, 87, 510-511. [CrossRef]

266. Weires, N.A.; Johnston, A.; Warner, D.L.; McCormick, M.M.; Hammond, K.; McDougal, O.M. Recycling of Waste Acetone by Fractional Distillation. J. Chem. Educ. 2011, 88, 1724-1726. [CrossRef]

267. Williamson, C.L.; Maly, K.E.; Macneil, S.L. Synthesis of Imidazolium Room-Temperature Ionic Liquids: A Follow-up to the Procedure of Dzyuba, Kollar, and Sabnis. J. Chem. Educ. 2013, 90, 799-801. [CrossRef]

268. Winter, R.T.; Van Beek, H.L.; Fraaije, M.W. The Nose Knows: Biotechnological Production of Vanillin. J. Chem. Educ. 2012, 89, 258-261. [CrossRef]

269. Wixtrom, A.; Buhler, J.; Abdel-Fattah, T. Mechanochemical Synthesis of Two Polymorphs of the Tetrathiafulvalene- Chloranil Charge Transfer Salt: An Experiment for Organic Chemistry. J. Chem. Educ. 2014, 91, 1232-1235. [CrossRef]

270. Worley, B.; Villa, E.M.; Gunn, J.M.; Mattson, B. Visualizing Dissolution, Ion Mobility, and Precipitation through a Low-Cost, Rapid-Reaction Activity Introducing Microscale Precipitation Chemistry. J. Chem. Educ. 2019, 96, 951-954. [CrossRef]

271. Wu, K.; Yu, L.; Ding, J. Synthesis of PCL-PEG-PCL Triblock Copolymer via Organocatalytic Ring-Opening Polymerization and Its Application as an Injectable Hydrogel-An Interdisciplinary Learning Trial. J. Chem. Educ. 2020, 97, 4158-4165. [CrossRef]

272. Wu, N.; Kubo, T.; Sekoni, K.N.; Hall, A.O.; Phadke, S.; Zurcher, D.M.; Wallace, R.L.; Kothari, D.B.; McNeil, A.J. Student-Designed Green Chemistry Experiment for a Large-Enrollment, Introductory Organic Laboratory Course. J. Chem. Educ. 2019, 96, $2420-2425$. [CrossRef]

273. Xie, Y.; Liu, X.; Tao, M. Synthesizing Substituted 2-Amino-2-Chromenes Catalyzed by Tertiaryamine-Functionalized Polyacrylonitrile Fiber for Students To Investigate Multicomponent Reactions and Heterogeneous Catalysis. J. Chem. Educ. 2016, 93, 2074-2079. [CrossRef]

274. Zhou, H.; Zhan, W.; Wang, L.; Guo, L.; Liu, Y. Making Sustainable Biofuels and Sunscreen from Corncobs to Introduce Students to Integrated Biorefinery Concepts and Techniques. J. Chem. Educ. 2018, 95, 1376-1380. [CrossRef]

275. Bumbaugh, R.E.; Ott, L.S. Preparing and Testing Novel Deep Eutectic Solvents from Biodiesel Co-Product Glycerol for Use as Green Solvents in Organic Chemistry Teaching Laboratories. ACS Symp. Ser. 2020, 1351, 113-130. [CrossRef]

276. Chateauneuf, J.E.; Nie, K. An Investigation of Friedel-Crafts Alkylation Reactions in Super- and Subcritical $\mathrm{CO}_{2}$ and under Solventless Reaction Conditions. ACS Symp. Ser. 2002, 819, 136-150. [CrossRef]

277. Ferhat, M.A.; Meklati, B.Y.; Visinoni, F.; Vian, M.A.; Chemat, F. Solvent Free Microwave Extraction of Essential Oils Green Chemistry in the Teaching Laboratory. Chim. Oggi 2008, 26, 48-50. 
278. Kohn, C. The Development of a Bioenergy-Based Green Chemistry Curriculum for High Schools. Phys. Sci. Rev. 2019, 4, 1-9. [CrossRef]

279. Slater, C.S. Partnerships with the Pharmaceutical Industry to Promote Sustainability Green Chemistry View Project Roadmap for Solvent Recovery in Industrial Manufacturing View Project. World Trans. Eng. Technol. Educ. 2011, 9, 6-11.

280. Warner, M.G.; Succaw, G.L.; Hutchison, J.E. Solventless Syntheses of Mesotetraphenylporphyrin: New Experiments for a Greener Organic Chemistry Laboratory Curriculum. Green Chem. 2001, 3, 267-270. [CrossRef]

281. Joshi, U.J.; Gokhale, K.M.; Kanitkar, A.P. Green Chemistry-Need of the Hour. Indian J. Pharm. Educ. Res. 2011, 45, 168-174.

282. Cunningham, A.D.; Ham, E.Y.; Vosburg, D.A. Chemoselective Reactions of Citral: Green Syntheses of Natural Perfumes for the Undergraduate Organic Laboratory. J. Chem. Educ. 2011, 88, 322-324. [CrossRef]

283. Dicks, A.P.; Hent, A.; Koroluk, K.J. The EcoScale as a Framework for Undergraduate Green Chemistry Teaching and Assessment. Green Chem. Lett. Rev. 2018, 11, 29-35. [CrossRef]

284. Gregor, R.W.; Goj, L.A. Solvent-Free Synthesis of 2,2'-Dinitrobiphenyl: An Ullmann Coupling in the Introductory Organic Laboratory. J. Chem. Educ. 2011, 88, 331-333. [CrossRef]

285. Lacušková, D.; Drozdíková, A. Biocatalytic Reduction of Ketones in a Secondary School Laboratory. Chem.-Didact.-Ecol.-Metrol. 2017, 22, 123-133. [CrossRef]

286. Palesch, J.J.; Gilles, B.C.; Chycota, J.; Haj, M.K.; Fahnhorst, G.W.; Wissinger, J.E. Iodination of Vanillin and Subsequent SuzukiMiyaura Coupling: Two-Step Synthetic Sequence Teaching Green Chemistry Principles. Green Chem. Lett. Rev. 2019, 12, 117-126. [CrossRef]

287. Rojas-Fernández, A.G.; Aguilar-Santelises, L.; Cruz Millán, M.; Aguilar-Santelises, M.; García-del Valle, A. Teaching Chemistry with Sustainability. Multidiscip. J. Educ. Soc. Technol. Sci. 2017, 4, 102. [CrossRef]

288. Tavener, S.; Hardy, J.; Hart, N.; Goddard, A. Teaching Green Chemistry: From Lemons to Lemonade Bottles. Green Chem. 2003, 5 , G46-G48. [CrossRef]

289. Young, D.M.; Welker, J.J.C.; Doxsee, K.M. Green Synthesis of a Fluorescent Natural Product. J. Chem. Educ. 2011, 88, 319-321. [CrossRef]

290. Houri, A.F.; Wehbe, H. Towards an Environmentally Friendly Chemistry Laboratory: Managing Expired Chemicals. Green Chem. R. Soc. Chem. 2003, 5, G49-G50. [CrossRef]

291. Van Arnum, S.D. Green Chemistry Fundamentals. J. Chem. Educ. 2005, 82, 1689-1692. [CrossRef]

292. McKenzie, L.C.; Huffman, L.M.; Hutchison, J.E.; Rogers, C.E.; Goodwin, T.E.; Spessard, G.O. Greener Solutions for the Organic Chemistry Teaching Lab: Exploring the Advantages of Alternative Reaction Media. J. Chem. Educ. 2009, 86, 488-493. [CrossRef]

293. Dintzer, M.R.; Wucka, P.R.; Lyons, T.W. Microwave-Assisted Synthesis of a Natural Insecticide on Basic Montmorillonite K10 Clay. Green Chemistry in the Undergraduate Organic Laboratory. J. Chem. Educ. 2006, 83, 270-272. [CrossRef]

294. Stark, A.; Ott, D.; Kralisch, D.; Kreisel, G.; Ondruschka, B. Ionic Liquids and Green Chemistry: A Lab Experiment. J. Chem. Educ. 2010, 87, 196-201. [CrossRef]

295. Ravía, S.; Gamenara, D.; Schapiro, V.; Bellomo, A.; Adum, J.; Seoane, G.; Gonzalez, D. Enantioselective Reduction by Crude Plant Parts: Reduction of Benzofuran-2-Y1 Methyl Ketone with Carrot (Daucus carota) Bits. J. Chem. Educ. 2006, 83, 1049-1051. [CrossRef]

296. Ribeiro, M.G.T.C.; Yunes, S.F.; Machado, A.A.S.C. Assessing the Greenness of Chemical Reactions in the Laboratory Using Updated Holistic Graphic Metrics Based on the Globally Harmonized System of Classification and Labeling of Chemicals. J. Chem. Educ. 2014, 91, 1901-1908. [CrossRef]

297. Armenta, S.; De La Guardia, M. Determination of Mercury in Milk by Cold Vapor Atomic Fluorescence: A Green Analytical Chemistry Laboratory Experiment. J. Chem. Educ. 2011, 88, 488-491. [CrossRef]

298. Sauvage, X.; Delaude, L. The Synthesis of N-Benzyl-2-Azanorbornene via Aqueous Hetero Diels-Alder Reaction. An Undergraduate Project in Organic Synthesis and Structural Analysis. J. Chem. Educ. 2008, 85, 1538-1540. [CrossRef]

299. Hooper, M.M.; De Boef, B. A Green Multicomponent Reaction for the Organic Chemistry Laboratory: The Aqueous Passerini Reaction. J. Chem. Educ. 2009, 86, 1077-1079. [CrossRef]

300. Phonchaiya, S.; Panijpan, B.; Rajviroongit, S.; Wright, T.; Blanchfield, J.T. A Facile Solvent-Free Cannizzaro Reaction: An Instructional Model for Introductory Organic Chemistry Laboratory. J. Chem. Educ. 2009, 86, 85-86. [CrossRef]

301. Ballard, E.C. pH-Controlled Oxidation of an Aromatic Ketone: Structural Elucidation of the Products of Two Green Chemical Reactions. J. Chem. Educ. 2010, 87, 190-193. [CrossRef]

302. Tundo, P.; Anthony, E.R.; Aricò, F. Methylation of 2-Naphthol Using Dimethyl Carbonate under Continuous-Flow Gas-Phase Conditions. J. Chem. Educ. 2010, 87, 1233-1235. [CrossRef]

303. Akers, S.M.; Conkle, J.L.; Thomas, S.N.; Rider, K.B. Determination of the Heat of Combustion of Biodiesel Using Bomb Calorimetry. A Multidisciplinary Undergraduate Chemistry Experiment. J. Chem. Educ. 2006, 83, 260-262. [CrossRef]

304. Lazarski, K.E.; Rich, A.A.; Mascarenhas, C.M. A One-Pot, Asymmetric Robinson Annulation in the Organic Chemistry Maiors Laboratory. J. Chem. Educ. 2008, 85, 1531-1534. [CrossRef]

305. Sidhwani, I.T.; Chowdhury, S. Greener Alternative to Qualitative Analysis for Cations without $\mathrm{H}_{2} \mathrm{~S}$ and Other Sulfur-Containing Compounds. J. Chem. Educ. 2008, 85, 1099-1101. [CrossRef]

306. Eby, E.; Deal, S.T. A Green, Guided-Inquiry Based Electrophilic Aromatic Substitution for the Organic Chemistry Laboratory. J. Chem. Educ. 2008, 85, 1426-1428. [CrossRef] 
307. Bopegedera, A.M.R.P.; Perera, K.N.R. "Greening" a Familiar General Chemistry Experiment: Coffee Cup Calorimetry to Determine the Enthalpy of Neutralization of an Acid-Base Reaction and the Specific Heat Capacity of Metals. J. Chem. Educ. 2017, 94, 494-499. [CrossRef]

308. Santos, E.S.; Garcia, I.C.G.; Gomez, E.F.L. Caring for the Environment While Teaching Organic Chemistry. J. Chem. Educ. 2004, 81, 232-238. [CrossRef] 